\title{
Nearshore Thermal Gradients of the Colorado River near the Little Colorado River Confluence, Grand Canyon National Park, Arizona
}

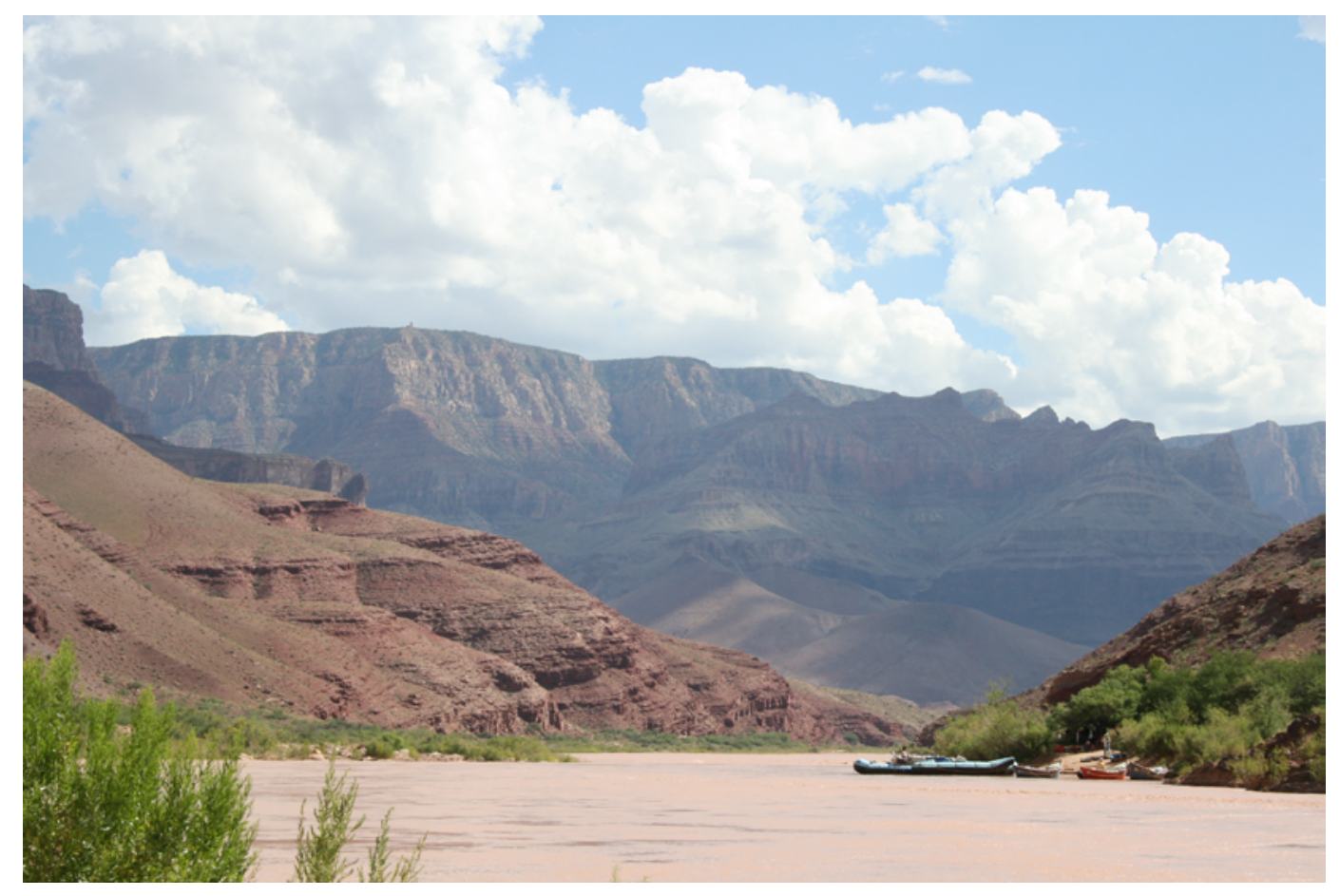

Open-File Report 2013-1013 


\section{U.S. Department of the Interior \\ KEN SALAZAR, Secretary}

\section{U.S. Geological Survey \\ Suzette M. Kimball, Acting Director}

U.S. Geological Survey, Reston, Virginia 2013

For product and ordering information:

World Wide Web: http://www.usgs.gov/pubprod

Telephone: 1-888-ASK-USGS

For more information on the USGS-the Federal source for science about the Earth, its natural and living resources, natural hazards, and the environment:

World Wide Web: http://www.usgs.gov

Telephone: 1-888-ASK-USGS

Suggested citation:

Ross, R.P., and Grams, P.E., 2013, Nearshore thermal gradients of the Colorado River near the Little Colorado River confluence, Grand Canyon National Park, Arizona, 2010: U.S. Geological Survey Open-File Report 2013-1013, 65 p.

Any use of trade, product, or firm names is for descriptive purposes only and does not imply endorsement by the U.S. Government.

Although this information product, for the most part, is in the public domain, it also may contain copyrighted materials as noted in the text. Permission to reproduce copyrighted items must be secured from the copyright owner. 


\section{Contents}

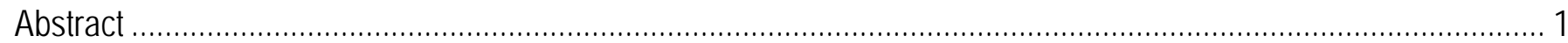

Introduction

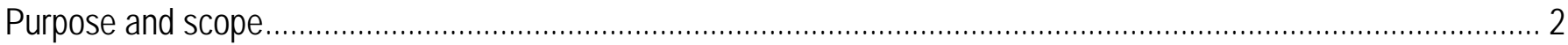

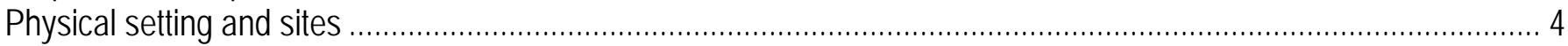

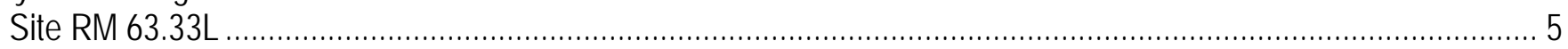

Site RM 63.56R

Site RM 63.65R

Site RM 63.81R

Site RM 64.29R

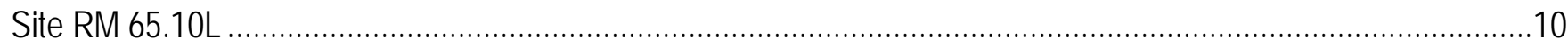

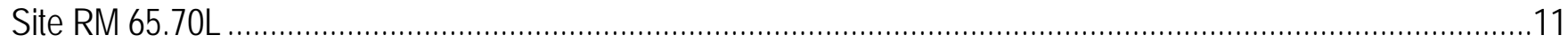

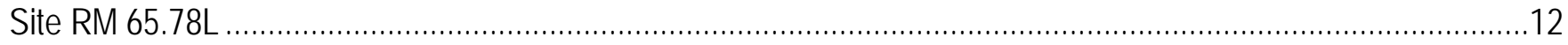

Methods

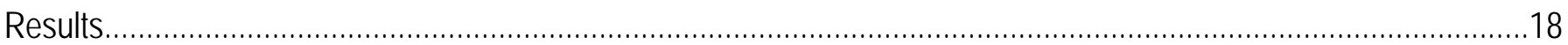

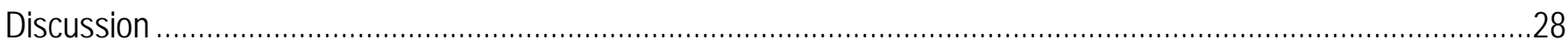

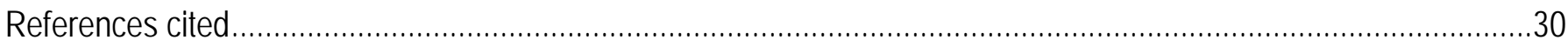

Appendix A. Results of Temperature-accuracy Tests on Thermistors …………….............................................31

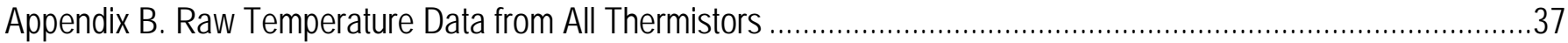

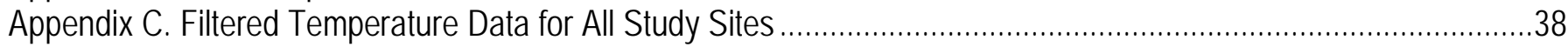

\section{Figures}

1. Location map of study area between Little Colorado River (LCR) and Lava Canyon Rapid................................... 3

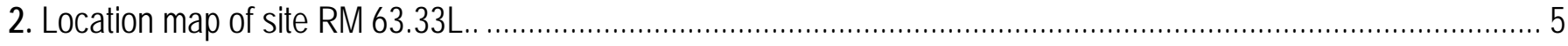

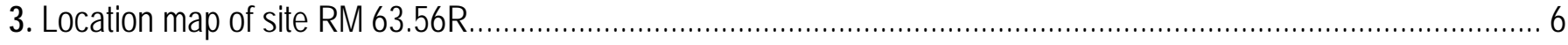

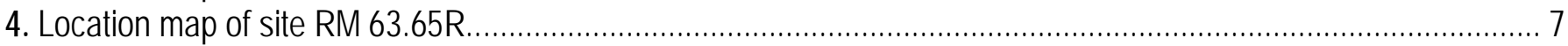

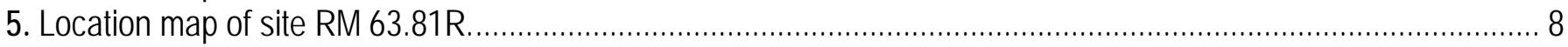

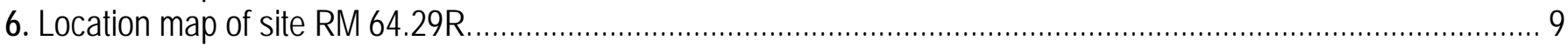

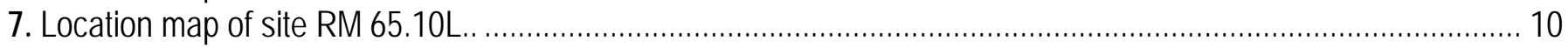

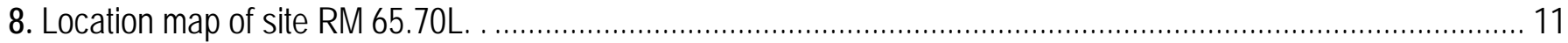

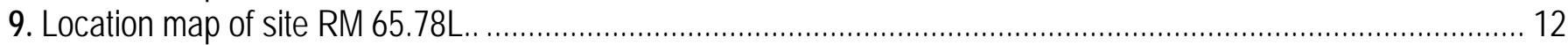

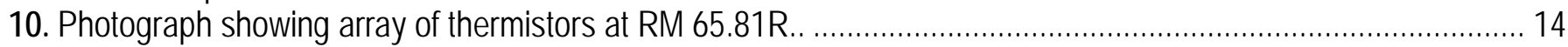

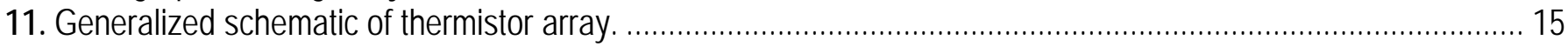

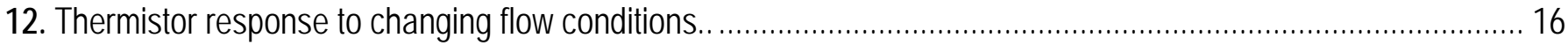

13. Average temperature differences from mainstem to shoreline for all study intervals........................................ 20

14. Examples of nearshore temperature during fluctuating flows in July and August, $2010(A-D)$ and September

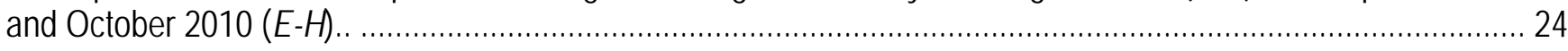

15. Comparison of consistently submerged thermistors during fluctuating flows (August) to similarly placed thermistors during steady flows (September).

16. Cumulative frequency distributions showing the fraction of time the thermal gradient from mainstem to

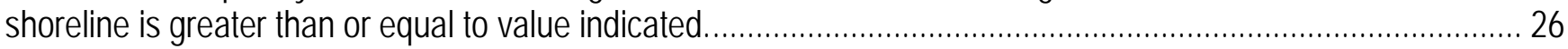

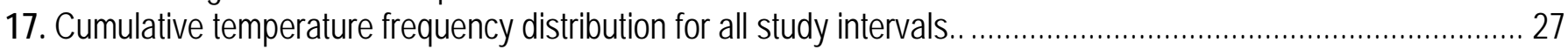

18. Average $(A)$ and maximum $(B)$ thermal gradients per meter $(\mathrm{dT} / \mathrm{dX})$ for all study sites/intervals.......................... 29 


\section{Tables}

1. List of temperature monitoring sites showing number of thermistors deployed, shoreline types, duration of instrumentation, spacing between thermistors, and approximate slope of site .. 4

2. Operational data for Onset Technologies HOBO Pro v2 Water Temperature datalogging thermistors..................... 14

3. Discharge ranges used to filter temperature data during fluctuating flow intervals. 17

4. Summary of discharge characteristics, mainstem water temperatures, air temperatures, and temperature gradients for each study interval. 


\section{Conversion Factors}

Inch/Pound to SI

\begin{tabular}{lcl}
\hline \multicolumn{1}{c}{ Multiply } & \multicolumn{1}{c}{ By } & \multicolumn{1}{c}{ To obtain } \\
\hline inch (in.) & Length & \\
inch (in.) & 2.54 & centimeter $(\mathrm{cm})$ \\
foot (ft.) & 25.4 & millimeter (mm) \\
mile (mi) & 0.3048 & meter (m) \\
\hline & 1.609 & kilometer $(\mathrm{km})$ \\
\hline square inch $\left(\mathrm{in}^{2}\right)$ & Area & \\
square mile $\left(\mathrm{mi}^{2}\right)$ & 6.452 & square centimeter $\left(\mathrm{cm}^{2}\right)$ \\
& 2.590 & square kilometer $\left(\mathrm{km}^{2}\right)$ \\
\hline cubic foot $\left(\mathrm{ft}^{3}\right)$ & Volume & \\
\hline & 0.02832 & cubic meter $\left(\mathrm{m}^{3}\right)$ \\
\hline cubic foot per second $\left(\mathrm{ft}^{3} / \mathrm{s}\right)$ & Flow rate & \\
cubic foot per day $\left(\mathrm{ft}^{3} / \mathrm{d}\right)$ & 0.02832 & cubic meter per second $\left(\mathrm{m}^{3} / \mathrm{s}\right)$ \\
\hline
\end{tabular}

Temperature in degrees Celsius $\left({ }^{\circ} \mathrm{C}\right)$ may be converted to degrees Fahrenheit $\left({ }^{\circ} \mathrm{F}\right)$ as follows:

${ }^{\circ} \mathrm{F}=\left(1.8 \mathrm{x}^{\circ} \mathrm{C}\right)+32$

Temperature in degrees Fahrenheit $\left({ }^{\circ} \mathrm{F}\right)$ may be converted to degrees Celsius $\left({ }^{\circ} \mathrm{C}\right)$ as follows:

${ }^{\circ} \mathrm{C}=\left({ }^{\circ} \mathrm{F}-32\right) / 1.8$

Horizontal coordinate information is referenced to North American Datum of 1983 (NAD 83). 
This page intentionally left blank 


\title{
Nearshore Thermal Gradients of the Colorado River near the Little Colorado River Confluence, Grand Canyon National Park, Arizona
}

\author{
By Robert P. Ross and Paul E. Grams
}

\begin{abstract}
Construction and operation of Glen Canyon Dam has dramatically impacted the flow of the Colorado River through Glen, Marble, and Grand Canyons. Extremes in both streamflow and water temperature have been suppressed by controlled releases from the dam. Trapping of sediment in Lake Powell, the reservoir formed by Glen Canyon Dam, has also dramatically reduced the supply of suspended sediment entering the system. These changes have altered the riverine ecosystem and the habitat of native species, including fish such as the endangered humpback chub (Gila cypha). Most native fish are adapted to seasonally warm water, and the continuous relatively cold water released by the dam is one of the factors that is believed to limit humpback chub growth and survival. While average mainstem temperatures in the Colorado River are well documented, there is limited understanding of temperatures in the nearshore environments that fish typically occupy. Four nearshore geomorphic unit types were studied between the confluence of the Colorado and Little Colorado Rivers and Lava Canyon in the summer and fall of 2010, for study periods of 10 to 27 days. Five to seven sites were studied during each interval. Persistent thermal gradients greater than the $0.2{ }^{\circ} \mathrm{C}$ accuracy of the instruments were not observed in any of the sampled shoreline environments. Temperature gradients between the shoreline and mainstem on the order of $4{ }^{\circ} \mathrm{C}$, believed to be important to the habitatseeking behavior of native or nonnative fishes, were not detected.
\end{abstract}

\section{Introduction}

The construction and operation of Glen Canyon Dam (GCD) has greatly changed the character of the Colorado River through Glen, Marble, and Grand Canyons. Dam operation for water storage and production of hydropower has resulted in reduced seasonal variations in flow, but much larger daily fluctuations (Topping and others, 2003). The average predam annual peak flow was about 87,000 cubic feet per second $\left(\mathrm{ft}^{3} / \mathrm{s}\right.$ ) and winter low flows were typically under 5,000 $\mathrm{ft}^{3} / \mathrm{s}$ (Topping and others, 2003). Current flows typically fluctuate by 5,000 to $8,000 \mathrm{ft}^{3} / \mathrm{s}$ on a daily basis, with daily maximum flows less than about 22,000 $\mathrm{ft}^{3} / \mathrm{s}$ and daily minimum flows greater than about $6,000 \mathrm{ft}^{3} / \mathrm{s}$. Because the water intake structure is at a fixed elevation deep in the reservoir, the water released from Glen Canyon Dam is cool and typically varies between 8 and $12{ }^{\circ} \mathrm{C}$ in comparison with predam seasonal variations of between 0 and $30^{\circ} \mathrm{C}$ (Wright and others, 2009). The changes in daily, seasonal, and annual temperature extremes have affected the aquatic habitat used by native species, including the humpback chub (Gila cypha). Temperature gradients along the shorelines are not well documented; previous work on mainstem shorelines (Korman and others, 2006; Vernieu and Andersen, unpublished data) has been limited to short durations of one to three days. Most temperature data collection has been in backwaters and shoreline cavities with some degree of isolation from the mainstem. A better understanding of both 
persistent and ephemeral temperature gradients relative to seasonal temperature variations and flow regime is needed to better predict the use of nearshore native fish habitats associated with various surficial geologic features, such as bedrock, talus slopes, cobble bars, and debris fans.

\section{Purpose and scope}

This report documents measurement and analysis of water temperatures in the mainstem Colorado River and nonisolated nearshore habitats between the Little Colorado River (LCR) and Lava Canyon Rapid (river miles [RMs] 61.10 to 65.78, respectively; fig. 1) from July 2010 to October 2010. We have used the term "mainstem" throughout the report to indicate main-channel flow with typical downstream velocity and a high degree of mixing. Sites were monitored during three intervals ranging from 10 to 26 days in July, August/September, and October. Although measurements are reported in SI system, locations and place names along the Colorado River are referred to by the convention of river miles (RM) downstream from Lees Ferry that was formalized in 2006 (U.S. Geological Survey, 2006). During the study period, the streamflow regime consisted of high-volume fluctuating flows in the summer and low-volume steady flows in the fall. We report both instantaneous and average temperatures and temperature gradients for seven study sites that encompass four different shoreline habitat types.

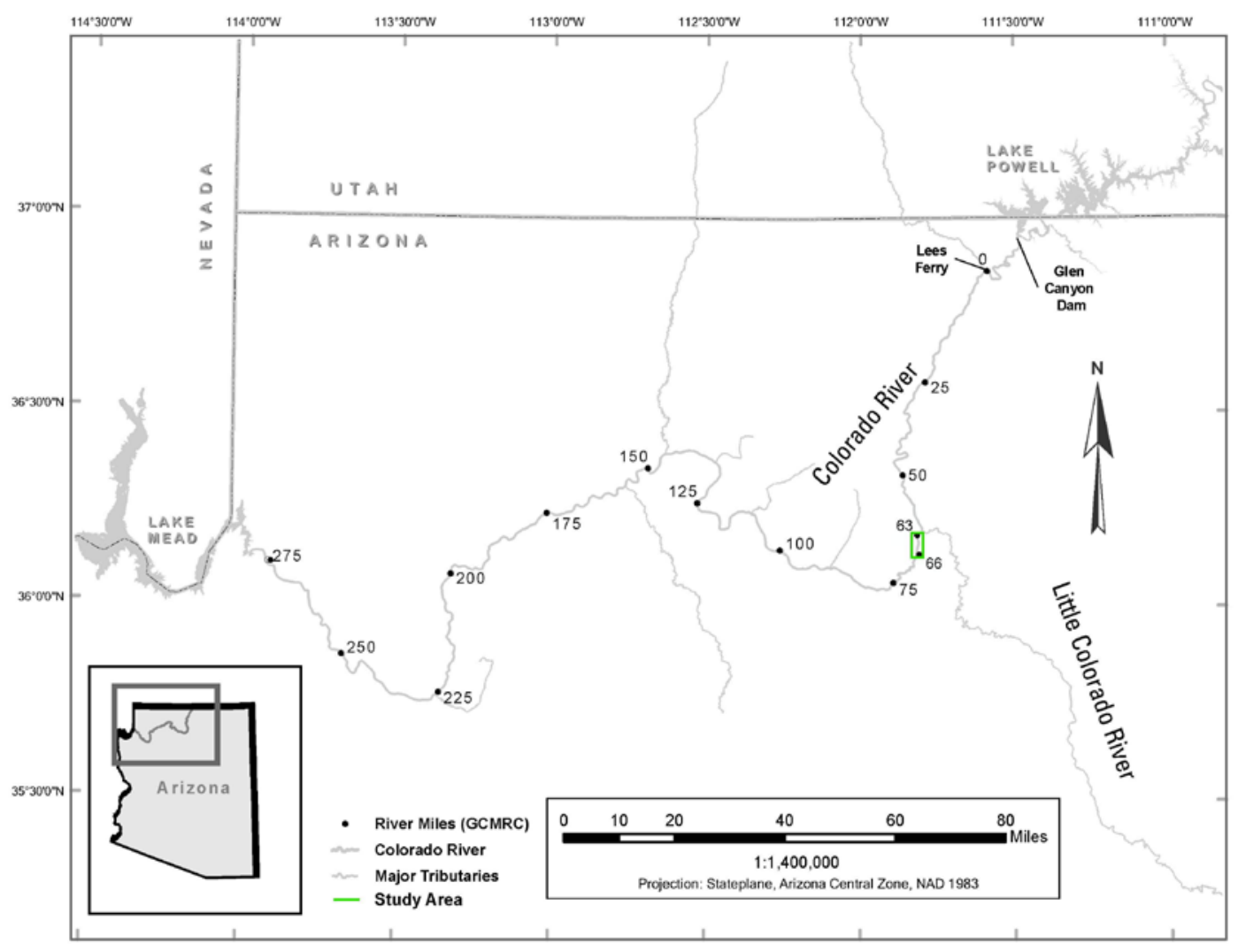

A 


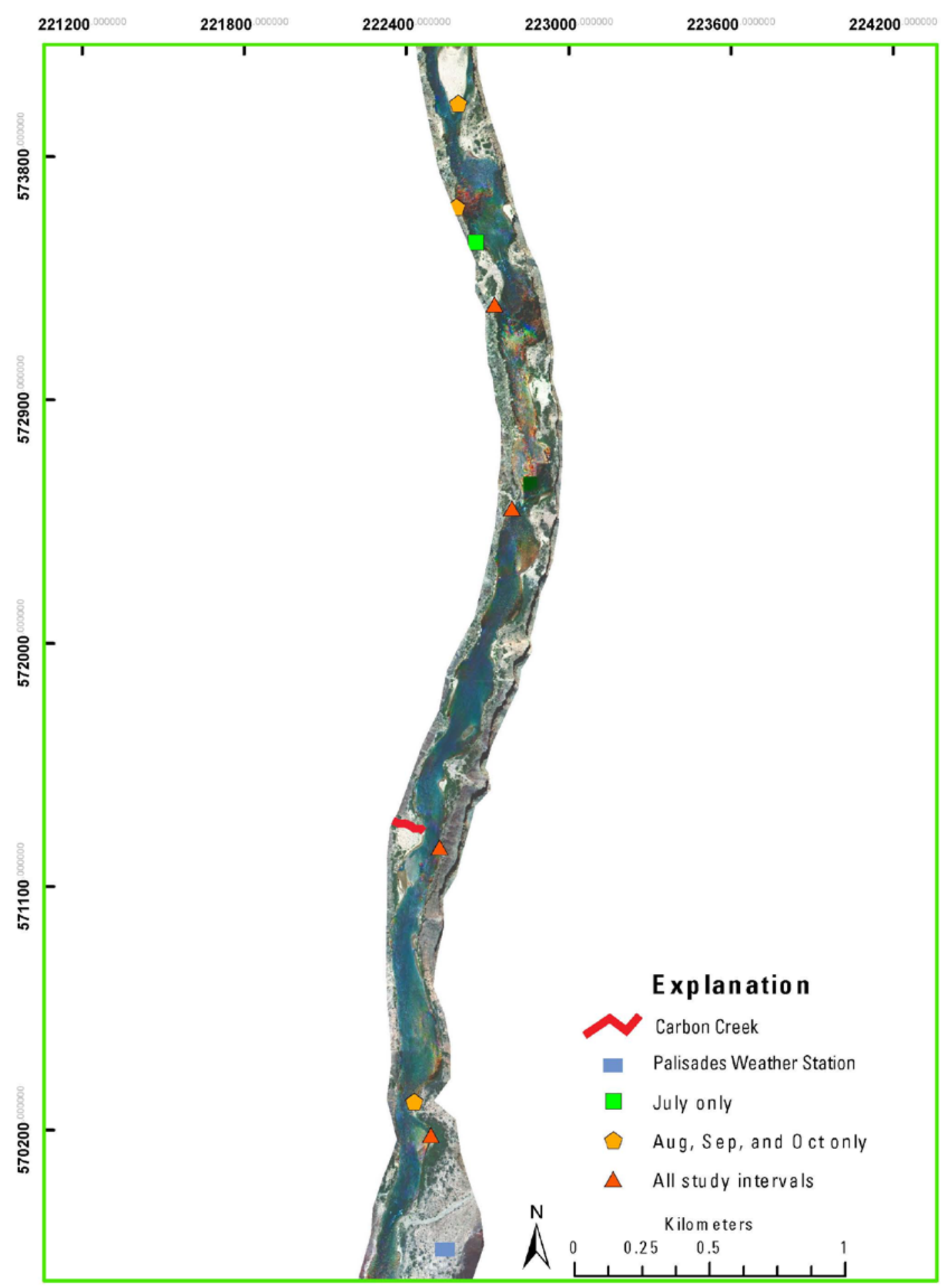

B

Figure 1. Location map of study area between Little Colorado River (LCR) and Lava Canyon Rapid, Grand Canyon National Park, Arizona. A, Study area (shown in green box) is from RM 63.33 to RM 65.78 in Grand Canyon. River miles show distance downstream from Lees Ferry, Arizona (U.S. Geological Survey, 2006). B, Detailed location map corresponding to inset study area in $A$. Red line is Carbon Creek, blue rectangle is Palisades weather station, and green squares, orange pentagons, and red triangles are locations of thermistor arrays. 


\section{Physical setting and sites}

Five sites were monitored during the first sampling interval (July 2010). An additional two sites were monitored in each of the subsequent sampling intervals to encompass the range of shoreline habitats where intensive fish sampling was being conducted in a concurrent study (Dodrill, 2012; table 1). The four shoreline habitat types that are the focus of fish monitoring utilize the most common classification of geomorphic features that occur in the reach: (1) debris fans and associated sandbars, (2) talus, (3) cobble bars, and (4) bedrock. We selected a greater number of debris fan and talus monitoring sites, because a greater proportion of the shoreline is composed of those feature classes. Each study site is referred to by river mile and either the left $(\mathrm{L})$ or right $(\mathrm{R})$ side of river when facing downstream.

Table 1. List of temperature monitoring sites showing number of thermistors deployed, shoreline types, duration of instrumentation, spacing between thermistors, and approximate slope of site.

\begin{tabular}{|c|c|c|c|c|c|c|c|c|}
\hline Site & RM 63.33R & RM 63.56R & RM 63.65R & RM 63.81R & RM 64.29R & RM 65.10L & RM 65.70L & RM 65.78L \\
\hline Approximate Slope $\mathrm{e}^{\mathrm{ii}}$ & 3 & 2 & 3 & 1 & 1 & 2 & 1 & 1 \\
\hline Deployment dates in July & $N / A$ & $N / A$ & $\begin{array}{l}7 / 12- \\
7 / 23 / 10\end{array}$ & $7 / 11-7 / 23 / 10$ & $7 / 11-7 / 23 / 10$ & $7 / 12-7 / 23 / 10$ & N/A & $7 / 11-7 / 23 / 10$ \\
\hline Thermistor spacing & & & $0.5 \mathrm{~m}$ & $1.0 \mathrm{~m}$ & $0.5 \mathrm{~m}$ & $0.5 \mathrm{~m}$ & & $0.5 \mathrm{~m}$ \\
\hline Deployment dates in August & $8 / 11-9 / 4 / 10$ & $8 / 11-9 / 4 / 10$ & $N / A$ & $8 / 11-9 / 4 / 10$ & $8 / 11-9 / 4 / 10$ & $8 / 10-9 / 4 / 10$ & $8 / 11-9 / 4 / 10$ & $8 / 10-9 / 4 / 10$ \\
\hline Thermistor spacing & $0.75 \mathrm{~m}$ & $0.75 \mathrm{~m}$ & & $1.0 \mathrm{~m}$ & $0.75 \mathrm{~m}$ & $0.5 \mathrm{~m}$ & $.75 \mathrm{~m}$ & $0.75 \mathrm{~m}$ \\
\hline Number of thermistors & 6 & 7 & & 6 & 7 & 5 & 6 & 5 \\
\hline $\begin{array}{c}\text { Deployment dates in } \\
\text { September }\end{array}$ & $9 / 4-9 / 15 / 10$ & $9 / 4-9 / 15 / 10$ & $N / A$ & $9 / 4-9 / 15 / 10$ & 9/4-9/15/10 & $9 / 4-9 / 15 / 10$ & $9 / 4-9 / 15 / 10$ & $9 / 4-9 / 15 / 10$ \\
\hline Deployment dates in October & $\begin{array}{l}10 / 16- \\
10 / 27 \\
\end{array}$ & $\begin{array}{c}10 / 16- \\
10 / 27 / 10 \\
\end{array}$ & $N / A$ & $\begin{array}{c}10 / 17- \\
10 / 27 / 10 \\
\end{array}$ & $\begin{array}{c}10 / 17- \\
10 / 27 / 10 \\
\end{array}$ & $\begin{array}{c}10 / 17- \\
10 / 27 / 10 \\
\end{array}$ & $\begin{array}{c}10 / 16- \\
10 / 27 / 10 \\
\end{array}$ & $\begin{array}{c}10 / 16- \\
10 / 27 / 10 \\
\end{array}$ \\
\hline Thermistor spacing & $0.5 \mathrm{~m}$ & $1.0 \mathrm{~m}$ & & $1.0 \mathrm{~m}$ & $1.0 \mathrm{~m}$ & $0.5 \mathrm{~m}$ & $1.0 \mathrm{~m}$ & $1.0 \mathrm{~m}$ \\
\hline Number of thermistors & 4 & 5 & & 6 & 5 & 5 & 5 & 5 \\
\hline
\end{tabular}




\section{Site RM 63.33L}

This site is located on the only cobble bar in the study reach (fig. 2). The bar is locally referred to as Hart Island and is a large cobble island in the center of the channel, with mainstem flow branching around either side. The island is dominated by medium to large cobbles (from 0.04 to $0.10 \mathrm{~m}$ in diameter) and has sparse vegetation. The instruments were located at the downstream end of the island in fast downstream-oriented current. The shoreline is relatively steep and reaches a water depth of about $2 \mathrm{~m}$ within about $2 \mathrm{~m}$ from shore at the range of discharges that were monitored. This site was instrumented in three monitoring periods_-August, September, and October 2010 (table 1).

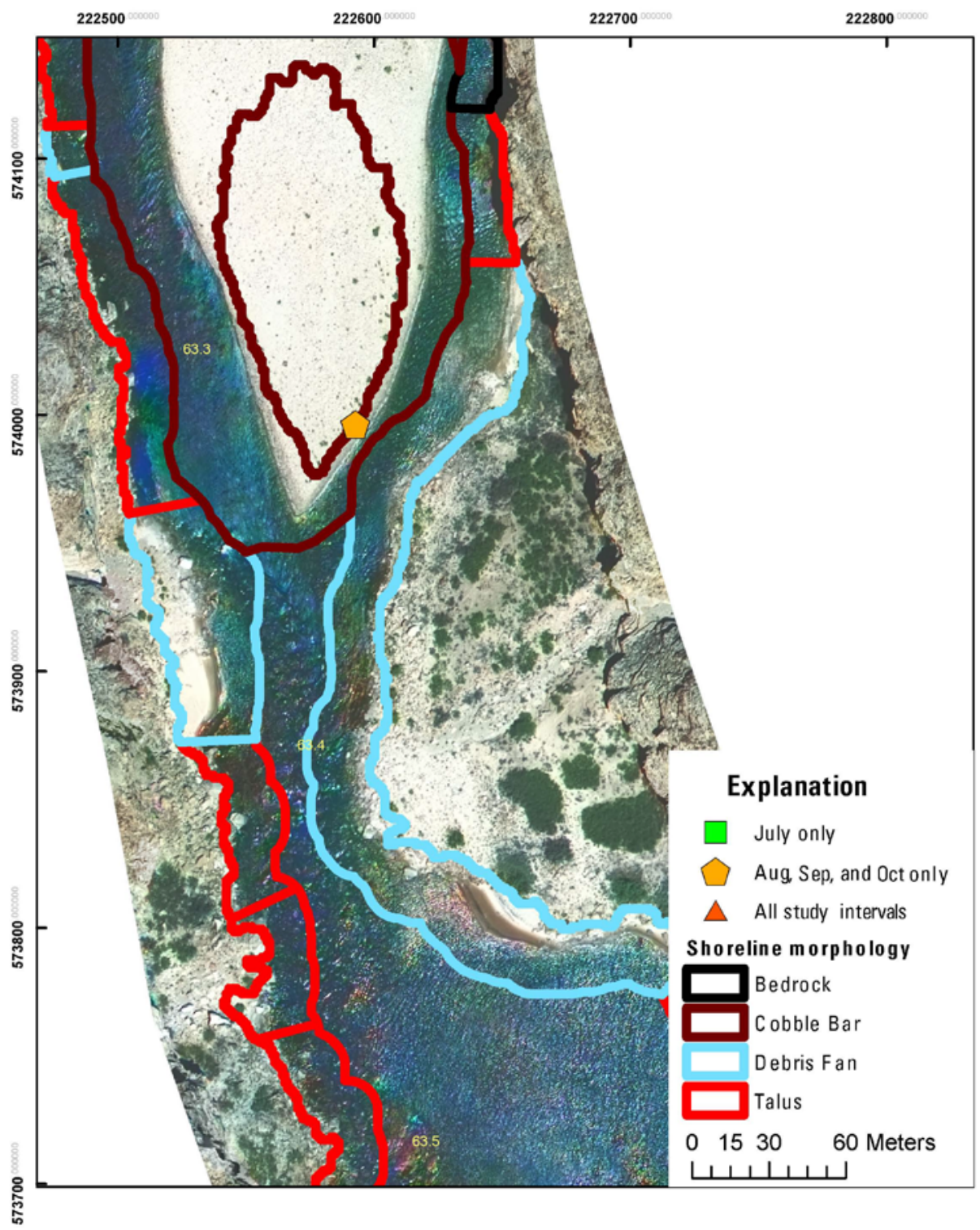

Figure 2. Location map of site RM 63.33L. Site is marked with an orange pentagon and was instrumented in the August, September, and October intervals. Site is located on the downstream end of a large cobble island and is in the cobble bar class of fish habitat sampling units. Direction of streamflow is from top to bottom. 


\section{Site RM 63.56R}

This site is located along a bedrock shoreline in an indentation that allowed access and installation of monitoring equipment (fig. 3). In addition to bedrock, there is a small sand deposit and isolated talus along the water edge. The slope into the main channel is steep, and current is mostly downstream, with a very weak eddy current. This site was instrumented from August to October (table 1).

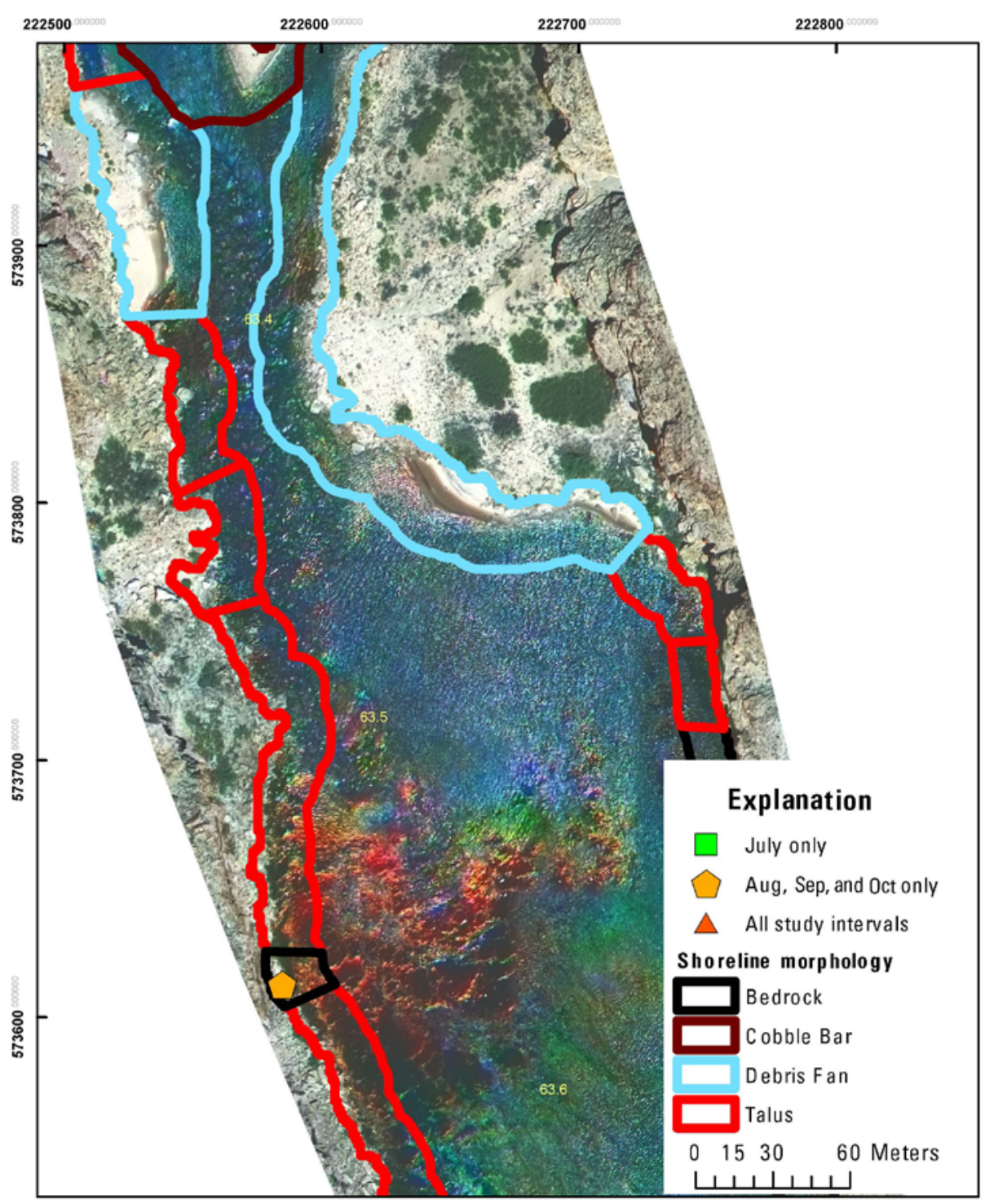

Figure 3. Location map of site RM 63.56R. Site is marked with an orange pentagon and was instrumented in the August, September, and October intervals. Site is located in a shoreline cavity that contacts bedrock and is in the bedrock class of fish habitat sampling units. Direction of streamflow is from top to bottom. 


\section{Site RM 63.65R}

This talus-dominated site is on the upstream end of a large debris fan (fig. 4). It is a steep rocky shoreline, with talus consisting of locally derived clasts on the order of 0.2 to $3 \mathrm{~m}$ in diameter. The talus continues into the channel along the full length of the thermistor array. The initial $0.5 \mathrm{~m}$ of the shoreline is low-angle due to shallow rock surface, but it then drops off abruptly to $2 \mathrm{~m}$ or deeper over the next $0.25 \mathrm{~m}$.

There is typically a small zone of upstream-directed eddy current in the nearest $1 \mathrm{~m}$ from the shoreline, and beyond that is downstream-oriented current. This site was only instrumented in July (table 1).

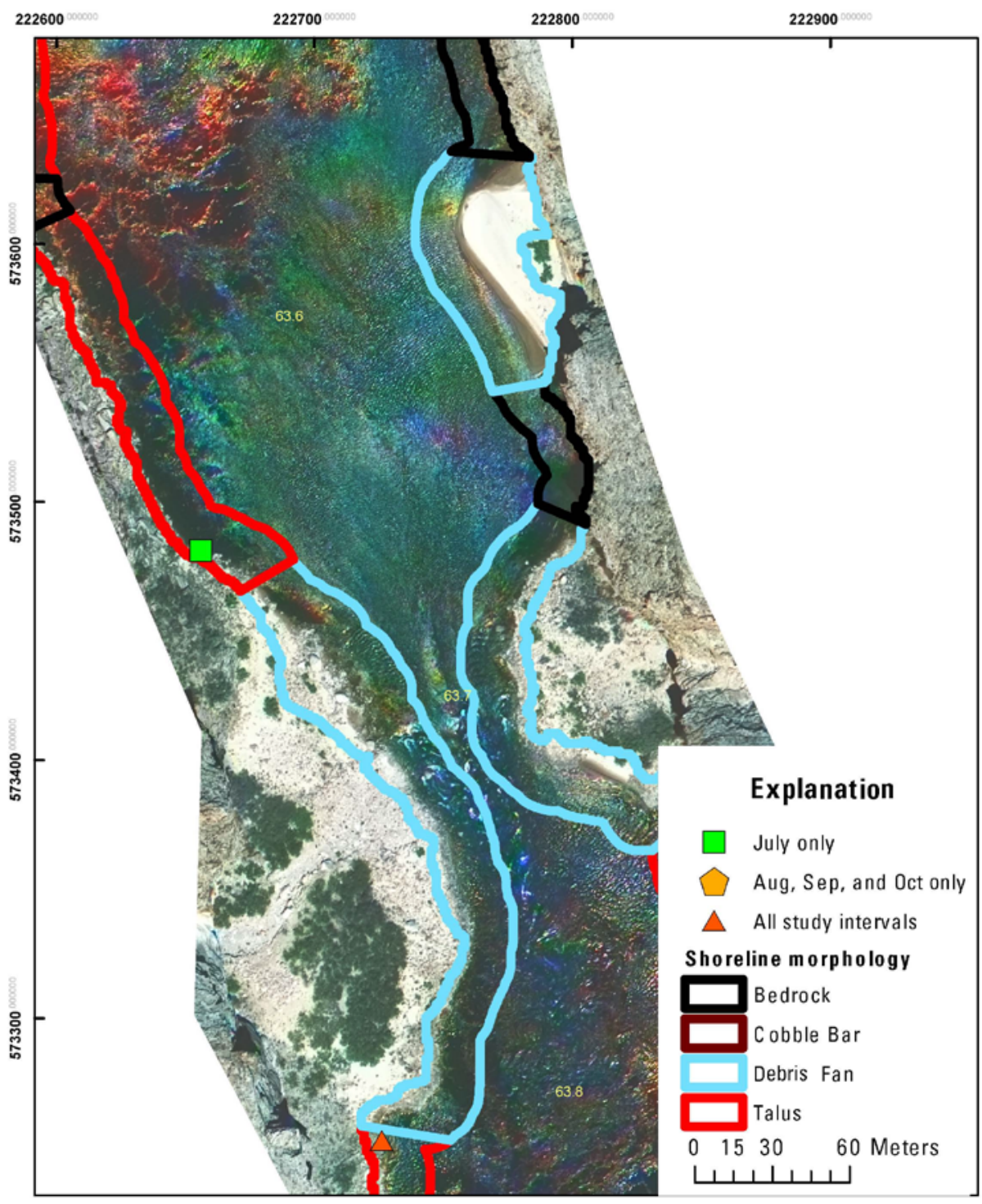

Figure 4. Location map of site RM 63.65R. Site is marked with a green square, and was only instrumented during the July monitoring interval. The site is located on the far upstream end of a debris fan and is in the talus class of fish habitat sampling units. Direction of streamflow is from top to bottom. 


\section{Site RM 63.81R}

This site is at the transition from a debris fan to talus-dominated shoreline, at the downstream end of the debris fan referenced for site RM 63.65R (fig. 5). The substrate along the thermistor string consists of large talus blocks. The site has a pronounced eddy current and is shallow and low-angle, not reaching $2 \mathrm{~m}$ in depth until about $8 \mathrm{~m}$ from shore. This site was instrumented for all intervals (table 1 ).

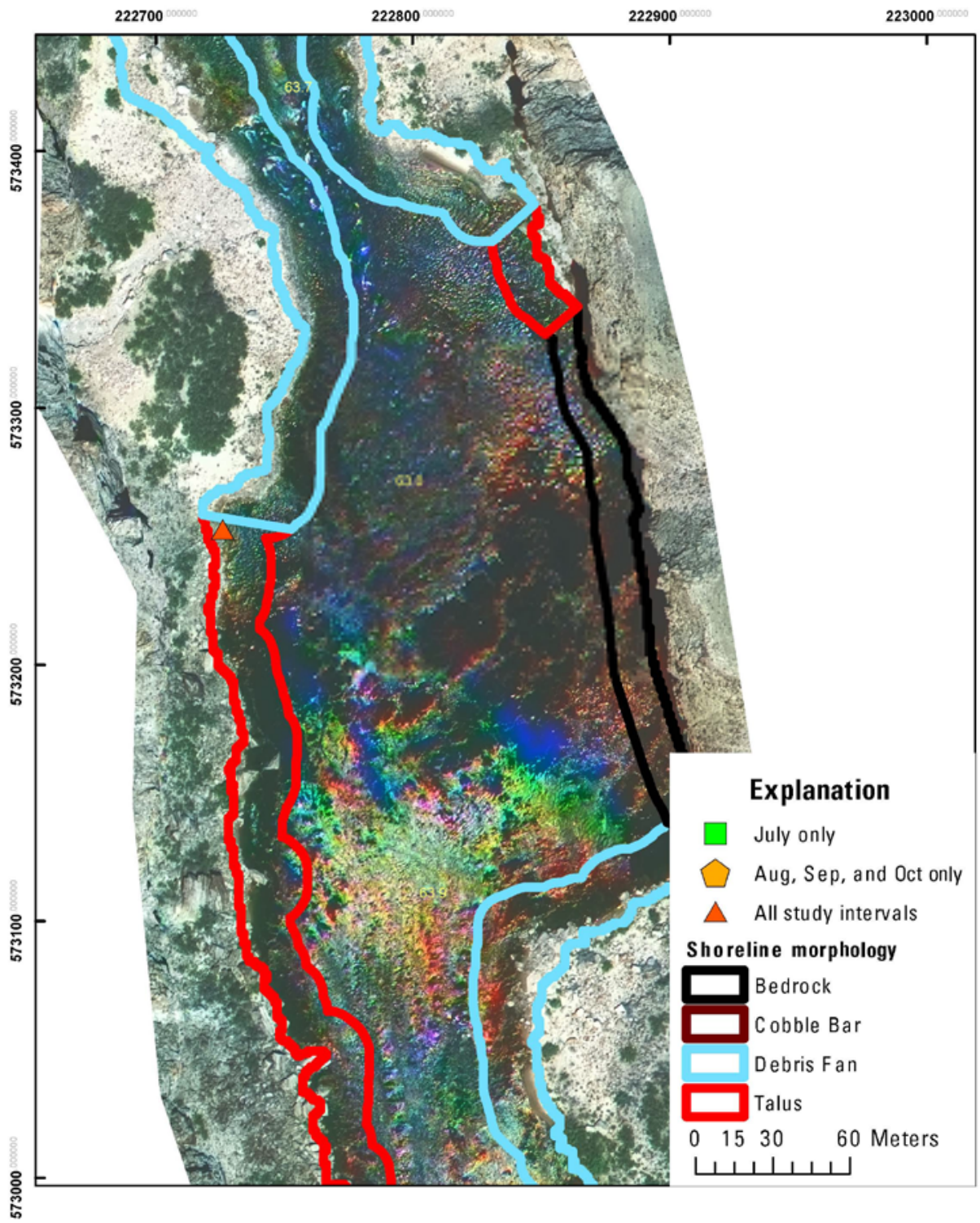

Figure 5. Location map of site RM 63.81R. Site is marked with a red triangle, and was instrumented during all study intervals. The site is located on the downstream end of large debris fan in a pronounced shoreline cavity and is situated at the transition point between debris fan and talus classes of fish habitat sampling units. Direction of streamflow is from top to bottom. 


\section{Site RM 64.29R}

This site on river-right is an extensive sandy shoreline associated with a large debris fan (fig. 6). The slope is low-angle, dropping to $2 \mathrm{~m}$ water depth over about $8 \mathrm{~m}$. The upper bank is heavily vegetated, while the lower bank is clear of vegetation due to the fluctuating flow regime over the lowangle shoreline. There is no noticeable eddy at this site; all current is downstream. This site was instrumented during all intervals, with a duplicate line installed during the October interval (table 1).

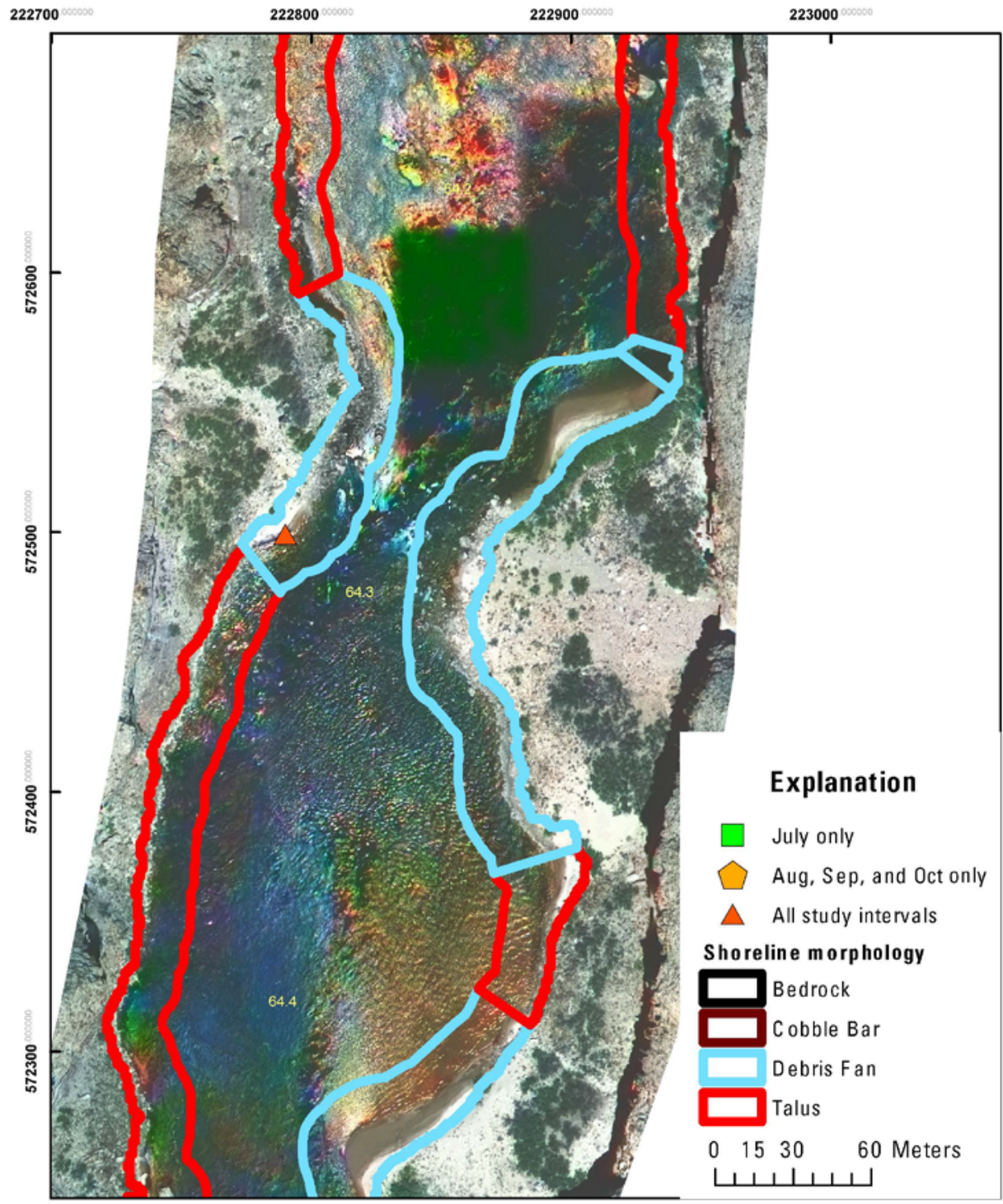

Figure 6. Location map of site RM 64.29R. Site is marked with a red triangle and was instrumented during all study intervals. The site is grouped within the debris fan class of fish habitat sampling units. Direction of streamflow is from top to bottom. 


\section{Site RM 65.10L}

This site is near Carbon Creek (fig. 1) along a talus shoreline with a moderately steep slope (fig. 7). Along the shoreline, the talus blocks have interstitial sand, and the bank is heavily vegetated. Talus boulders continue into the channel, and the shoreline drops over the course of $\sim 3 \mathrm{~m}$ to more than $2 \mathrm{~m}$ depth. A small, weak eddy current exists, but the site has mostly downstream flow. It was instrumented during all intervals (table 1 ).

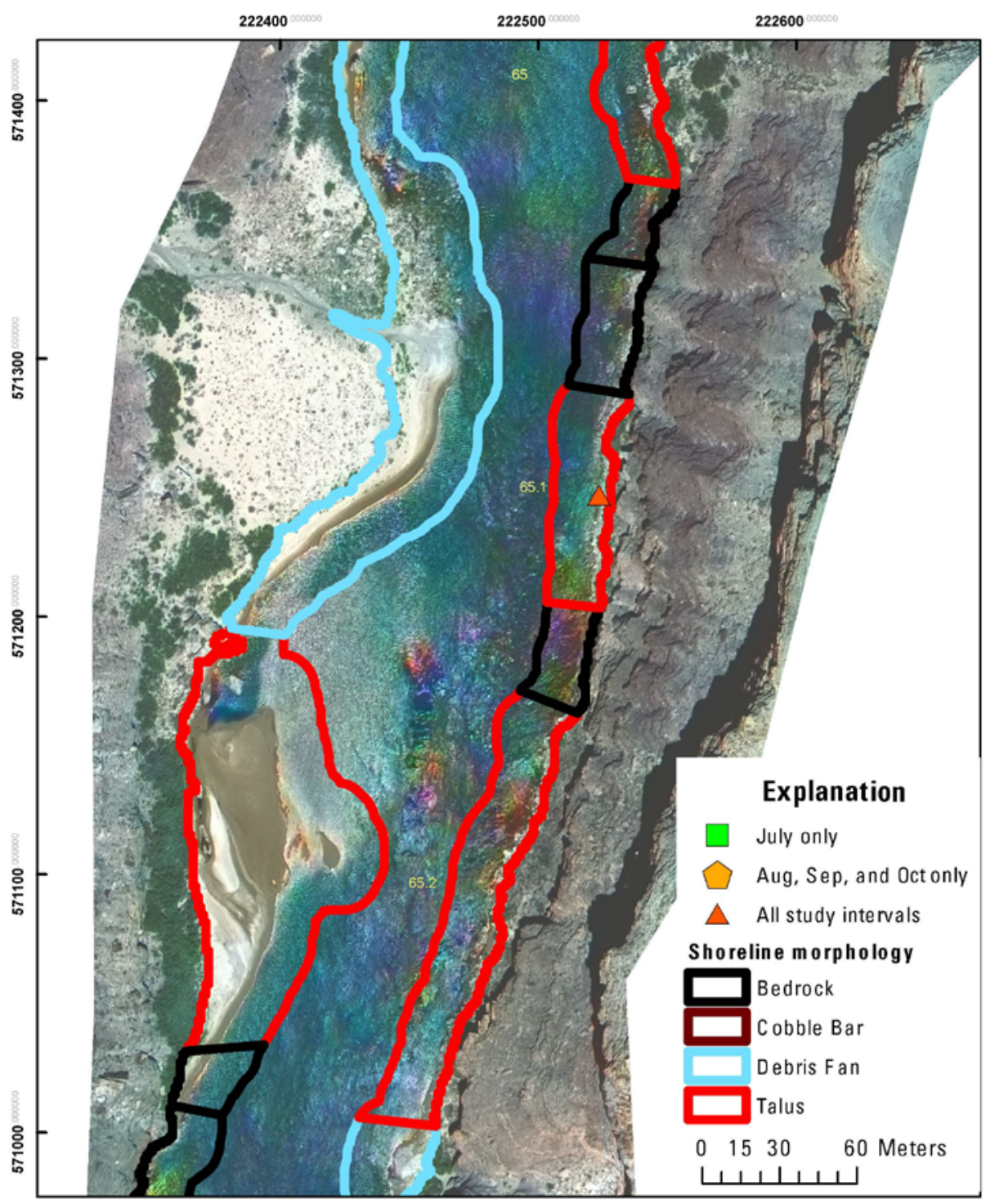

Figure 7. Location map of site RM 65.10L. Site is marked with a red triangle and was instrumented during all study intervals. Site is located on the toe of large talus cone and is within the talus class of fish habitat sampling units. Direction of streamflow is from top to bottom. 


\section{Site RM 65.70L}

This site is located at the upstream end of the debris fan that is upstream from site RM 65.78L (fig. 8). It is at the mouth of a tributary drainage, and the substrate is sand intermixed with well-sorted gravel, cobbles, and boulders. The debris fan is heavily vegetated. The thermistor string was located within a small eddy created by bank irregularaties along the shoreline of the debris fan. The shoreline is low-angle over the first $2 \mathrm{~m}$, with a rapid increase to $2 \mathrm{~m}$ depth over the next $2 \mathrm{~m}$. This site was instrumented from August to October (table 1).

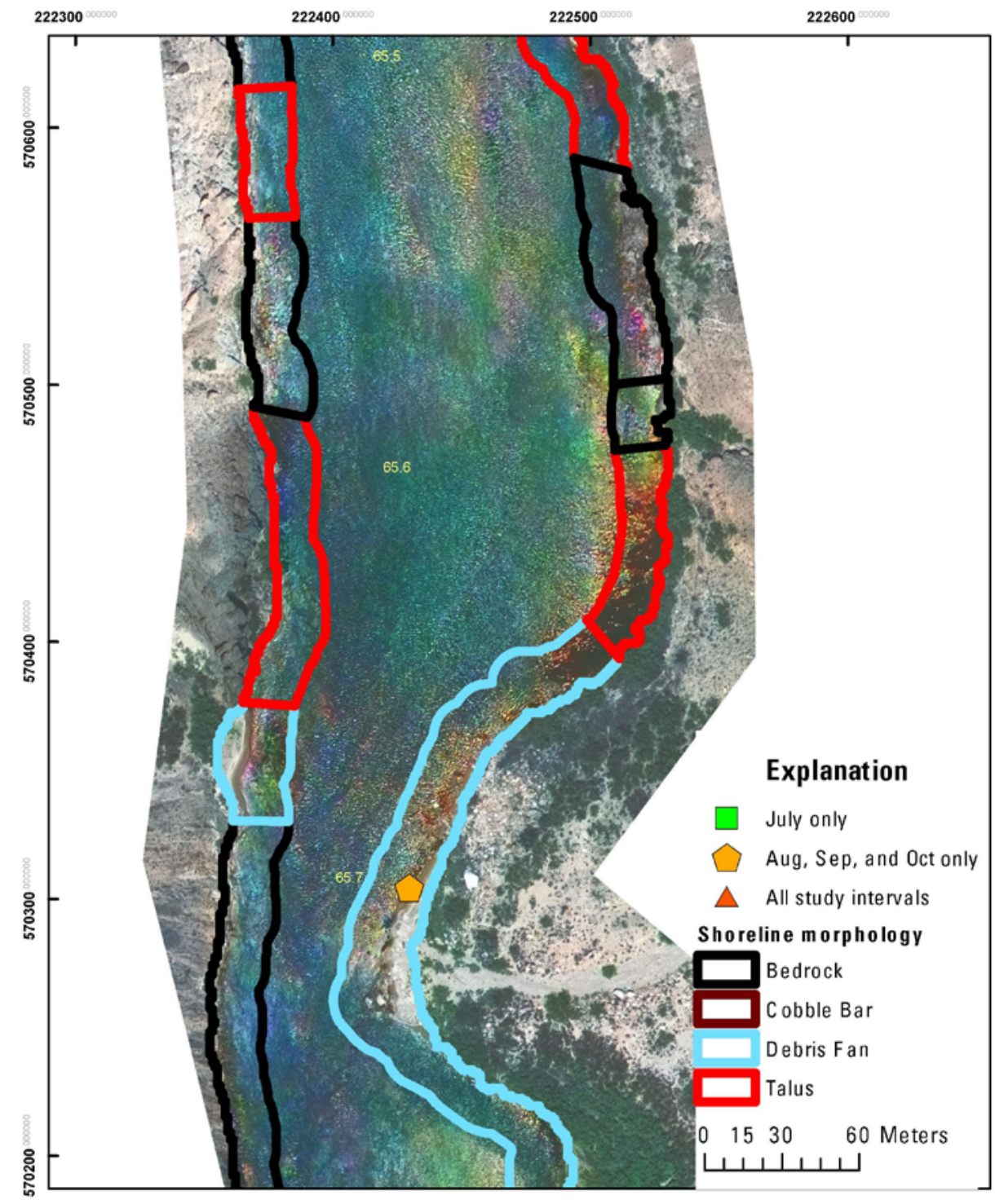

Figure 8. Location map of site RM 65.70L. Site is marked with an orange pentagon and was instrumented in the August, September, and October study intervals. The site is located at mouth of a debris fan and is within the debris fan class of fish habitat sampling units. Direction of streamflow is from top to bottom. 


\section{Site RM 65.78L}

This site is located within a large eddy downstream from a prominent debris fan (fig. 9). The shoreline where the thermistor string was located is composed of sand and is sparsely covered with vegetation. The character of this shoreline varied among the sampling intervals, because sand deposition occurred during the transition from fluctuating flows during the summer to steady flow in September. Following that transition, a large sandbar projected into the channel and changed the slope of the site significantly. There is an eddy current at this site near shore. This site was instrumented during all intervals (table 1).

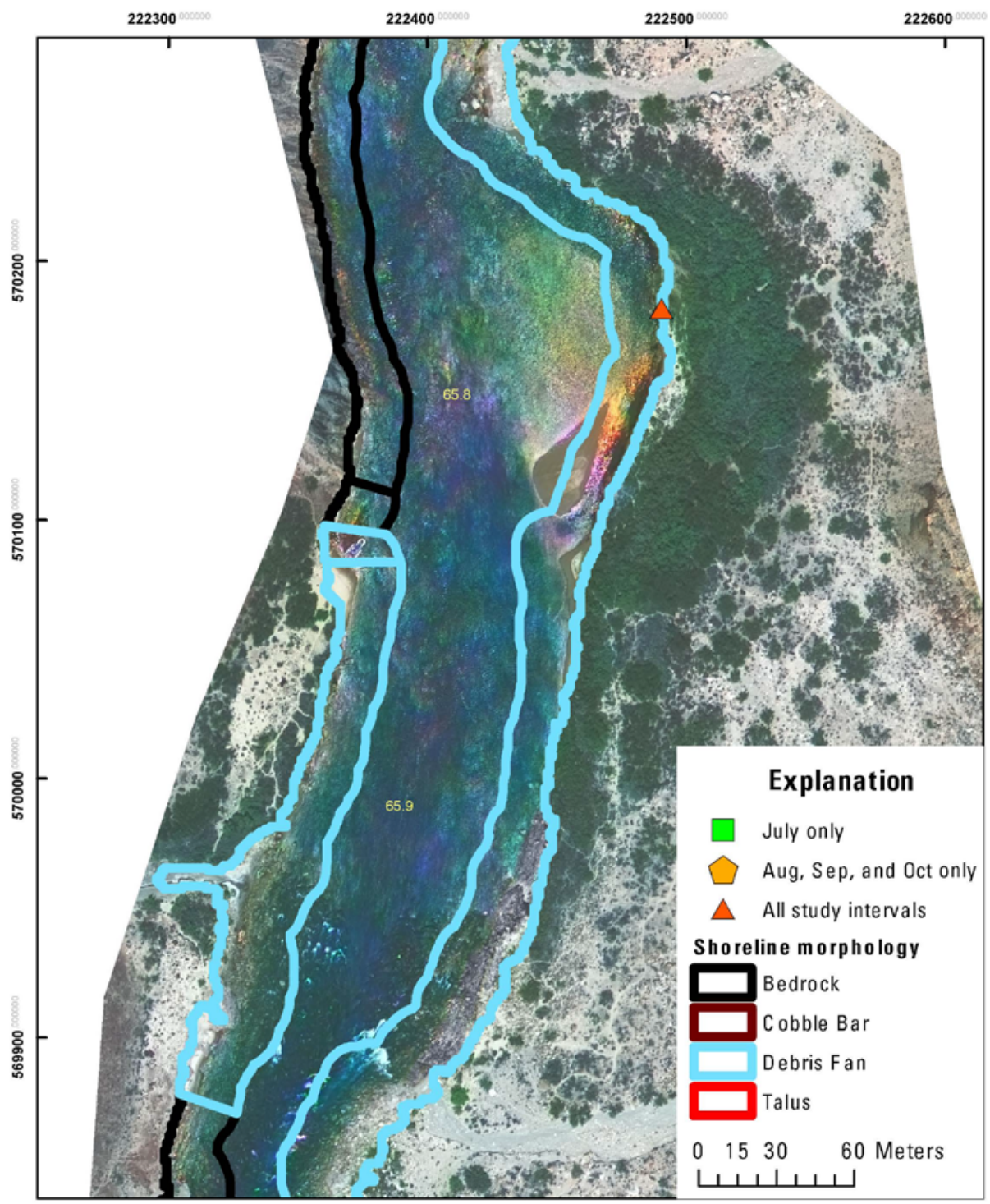

Figure 9. Location map of site RM 65.78L. Site is marked with a red triangle and was instrumented during all study intervals. Site is located downstream from a debris fan, above Lava Canyon Rapid, and is within the debris fan class of fish habitat sampling units. Direction of streamflow is from top to bottom. 


\section{Methods}

Nearshore temperatures were monitored during unsteady flow conditions in July and August (July 11-23 and August 11-September 4, 2010) and relatively steady flow conditions in September and October (September 5-25 and October 17-27, 2010). Flow fluctuated from approximately 9,250 to $22,850 \mathrm{ft}^{3} / \mathrm{s}$ in the fluctuating-flow regime of July and August, and from approximately 8,200 to 8,800 $\mathrm{ft}^{3} / \mathrm{s}$ in the steady flow regime of September and October. Note that steady flow still entails some fluctuation, due to inputs from the Little Colorado River (LCR) and other tributaries. Discerning local discharge at the study sites was problematic, as different flows, rates of change to flow, and variable conditions led to varying travel times of changes in flow. To remedy this, local discharge data was modeled using the program Colorado River Flow and Sediment (CRFS; after Wiele and Griffin, 1997; Ecometric Research, Inc., v.1.0.1.0, Canmore, Alberta, Canada, 2011), using discharge data from gages maintained by the Grand Canyon Monitoring and Research Station (GCMRC) located at RM 60.88 and above the mouth of the LCR at RM 61.7. Modeled output was considered at cross sections near each site to approximate instantaneous discharge for all monitoring periods. Air temperatures were compiled from the nearby Palisades weather station about $708 \mathrm{~m}$ downstream and about $138 \mathrm{~m}$ inland from site RM 65.78L.

Thermal gradients and temperature differences for this study are considered latitudinal changes from the shoreline to the mainstem channel. Thermal gradients are measurements of average temperature change per meter $\left({ }^{\circ} \mathrm{C} / \mathrm{m}\right)$, and temperature differences are the absolute change in temperature between measurement points $\left({ }^{\circ} \mathrm{C}\right)$. Arrays of HOBO Pro v2 Water Temperature Data Logger thermistors (manufactured by Onset Computer Corp., Bourne, MA) were deployed at each site perpendicular to the shoreline (table 1; fig. 10). Each thermistor measured and recorded temperature at coincident 15 -minute intervals, with published accuracy of $\sim 0.2^{\circ} \mathrm{C}$ and resolution of $0.02{ }^{\circ} \mathrm{C}$ (table 2 ). Accuracy tests conducted during the course of this study indicate a better-than-published accuracy for these units, between 0.1 and $0.14^{\circ} \mathrm{C}$ (appendix A). The thermistors were programmed with a scheduled start time, and were downloaded after retrieval; the use of a computer in the field was unnecessary. The downloaded files were exported as comma-delimited text files, and were subsequently organized by site and distance from shoreline (appendix B). Instruments were attached to a floating polypropylene line (lengths varying from $3 \mathrm{~m}$ to $8 \mathrm{~m}$ ) at spacing determined by site characteristics (between 0.5 and $1.0 \mathrm{~m}$, with increased spacing over sites with low-angle shorelines). The thermistors were attached with cable ties in a downward orientation, to minimize chances of thermistors rotating to the top of the line. The floating lines were attached at the shoreline either to existing rocks and (or) vegetation, or rebar where existing attachment points were not available. A system of buoys made from sealed PVC pipe, scuba weights attached to nylon line, and rocks attached with cable ties was engineered to keep thermistors continuously submerged approximately $2 \mathrm{~cm}$ below the water surface (fig. 11). As the stage changes during fluctuating flows, the thermistors near the shoreline are often exposed subaerially or submerged in shallow water depths as the shoreline recedes or advances (fig. 12). 


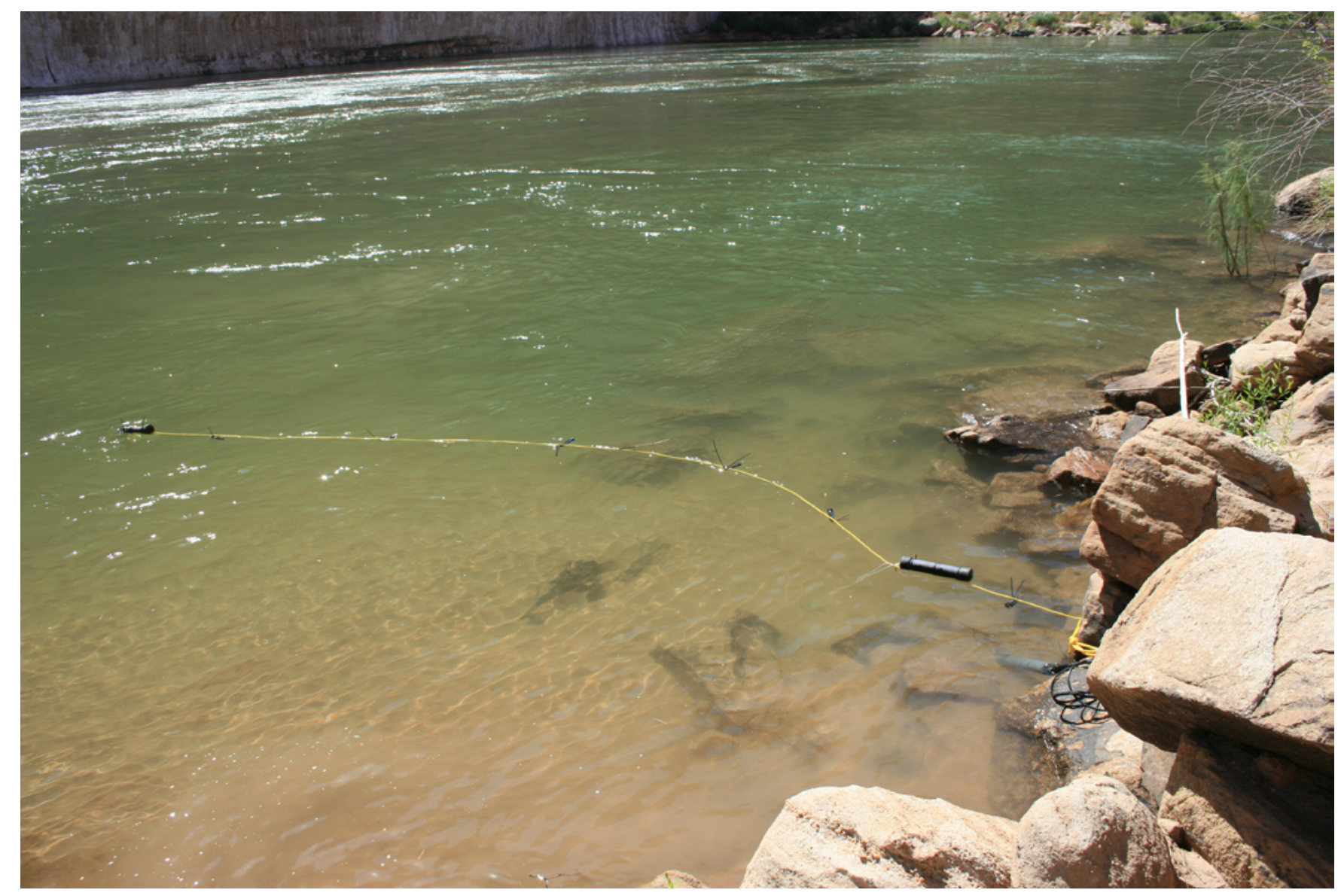

Figure 10. Photograph showing array of thermistors at RM 65.81R. This 6-m instrument string has six thermistors deployed at approximately 1-m intervals. View is from the right bank of the river looking downstream.

Table 2. Operational data for Onset HOBO Pro v2 Water Temperature data logging thermistors.

[Thermistor specifications available at

http://www.onsetcomp.com/callback/show-specs?n=2331]

\begin{tabular}{ccccc} 
Operation Range & Accuracy & Resolution & Response time & Stability \\
\hline $\begin{array}{c}40{ }^{\circ} \mathrm{C} \text { to } 70{ }^{\circ} \mathrm{C}(\text { air); } \\
\begin{array}{c}\text { Max sustained } 50^{\circ} \mathrm{C} \\
\text { water }\end{array}\end{array}$ & $\begin{array}{c}0.2^{\circ} \mathrm{C} \text { over } \\
0{ }^{\circ} \mathrm{C} \text { to } 50\end{array}$ & $0.02{ }^{\circ} \mathrm{C} @ 25^{\circ} \mathrm{C}$ & 5 minutes in water & $0.1{ }^{\circ} \mathrm{C} / \mathrm{yr}$ \\
\hline Clock & Battery life & Memory & Buoyancy & Shock \\
\hline \pm 1 minute/month & 6 years & $64 \mathrm{~Kb}$ & +13 grams & 1.5 meter \\
\hline
\end{tabular}




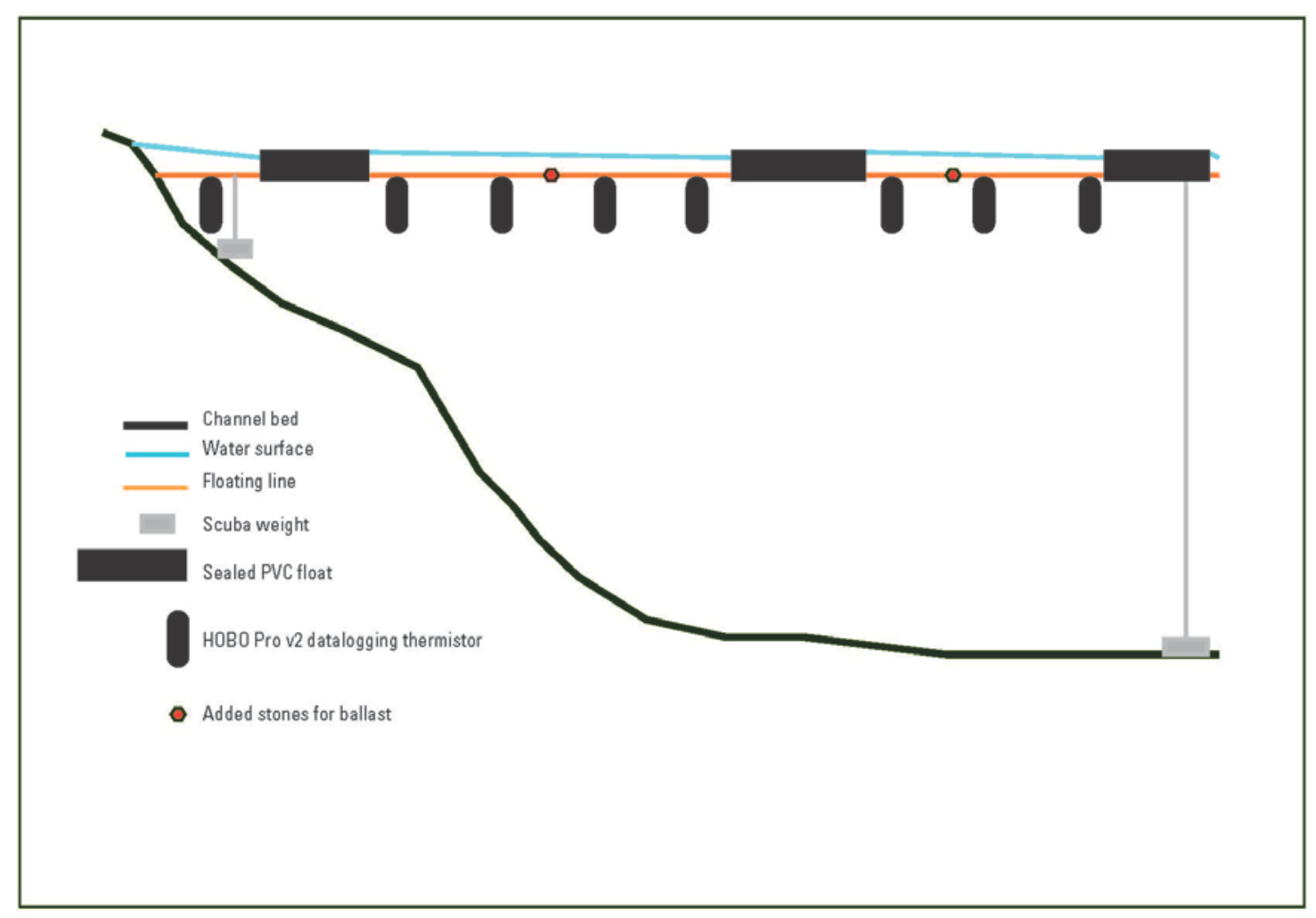

Figure 11. Generalized schematic of thermistor array. System is composed of sealed PVC pipe floats, floating line, scuba weights, and stone ballasts, with Onset Technologies HOBO Pro v2 Water Temperature data logging thermistors. Floating lines were attached to the shoreline with either rebar or natural anchors, and floats and weights were arranged such that thermistors were positioned approximately $0.02 \mathrm{~m}$ below water surface. The floats and stone ballasts kept submerged thermistors in this orientation during fluctuating flows, and the scuba weights fixed the lines in a position perpendicular to the shoreline. 


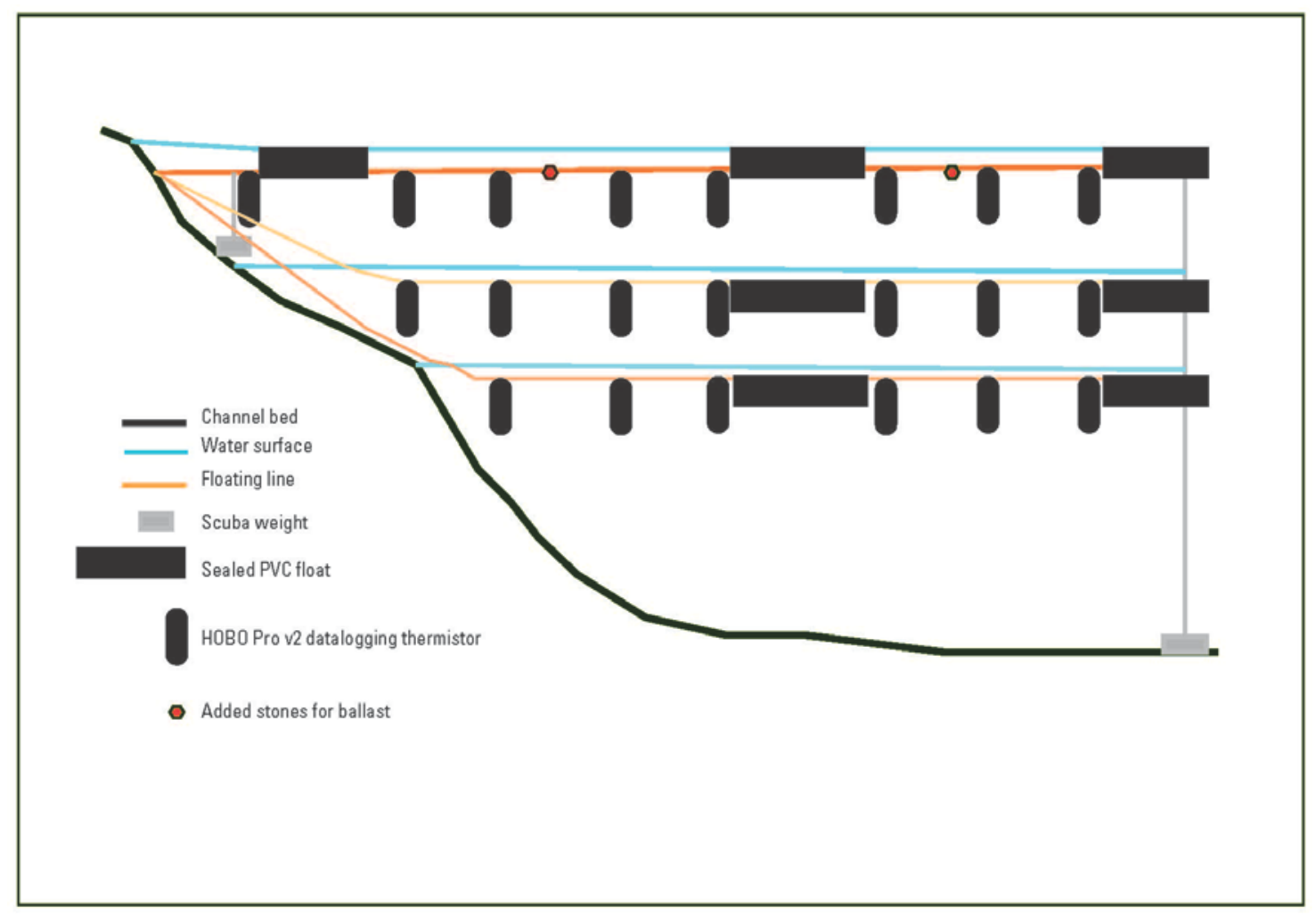

Figure 12. Thermistor response to changing flow conditions. Generalized schematic shows how instrument line drops with water surface when flow decreases. Line is attached to fixed point on shore, and as flow decreases, nearshore thermistors become subaerial. At lowest discharge, the effective shoreline (the area where the first submerged thermistor is) moves towards the mainstem of the channel. Floats, ballast, and weights keep the instrument line perpendicular to shore, and instruments remain approximately $0.02 \mathrm{~m}$ below water surface.

The data were filtered to remove values recorded when the thermistors were exposed above the water surface, which occurred during the low-flow periods during fluctuating flows in July and August, as well as during some periods of steady flow in September and October (note there is still natural variation from the LCR input during this time period). The filter was based on modeled local discharge values at each 15-minute interval created with CRFS. Periods of known exposure were compared to discharge values to approximate the point in upramp or downramp fluctuation at which each thermistor became exposed (table 3). Because of differences in duration of release between the two legs of the flow change, the thermistors respond differently, relative to the varying rates of stage increase/decrease. Since the local modeled discharge is approximate, and the pattern of exposure is different for each site and change in flow, a range of discharge at which a thermistor is becoming subaerial or subaqueous is reported (table 3). Gross filtering was done based on discharge values where exposure was known, and then data were manually inspected for changes in discharge ranges where exposure was questionable (table 3). This procedure was applied to the fluctuating flow periods, and the data were manually filtered for the steady flow periods.

The filtered data were inspected and compared to the unfiltered data, and any data that were erroneously filtered were replaced. The filtered temperature data were plotted as a time series to inspect 
the patterns of change in temperature relative to daily flow fluctuations (appendix $\mathrm{C}$ ). Mean temperatures and temperature gradients were tabulated for a.m. and p.m. intervals (00:00 - 12:00, and 12:00 - 24:00, respectively), and as a daily value. The gradient between the shoreline and mainstem temperatures was calculated as $d T / d x$, where

and

$$
d T=(T \text { initial submerged thermistor }-T \text { terminal thermistor })
$$

$$
\begin{array}{r}
d x=\text { (distance from shore of initial submerged thermistor } \\
- \text { - distance from shore of terminal thermistor) }
\end{array}
$$

where $T$ is temperature in degrees Celsius. This calculation provides a metric of temperature gradient in degrees $\mathrm{C}$ per meter, and the temperature change over the entire instrument array, for each thermistor location.

Table 3. Discharge ranges used to filter temperature data during fluctuating flow intervals.

[The first number is the discharge $(\mathrm{Q})$ at which the thermistor is known to be submerged at all Q greater than or equal to value, and second number is discharge at which the thermistor is known to be subaerial at all Q less than or equal to value. The comparisons are very approximate, given the nature of the modeled local discharge, and all data were carefully examined in context with magnitude of changes, air temperatures, mainstem temperature, and discharge to determine what

\begin{tabular}{|c|c|c|c|c|c|c|c|c|c|c|}
\hline July & 0 & 1 & 2 & 3 & 4 & 5 & 6 & 7 & 8 & 9 \\
\hline $63.65 \mathrm{R}$ & $\begin{array}{l}15900 \\
15600\end{array}$ & $\begin{array}{l}15300 \\
14900\end{array}$ & $\begin{array}{l}13000 \\
12200\end{array}$ & $\begin{array}{l}12900 ; \\
11000\end{array}$ & $\begin{array}{l}12900 ; \\
11000\end{array}$ & $\begin{array}{l}12600 \\
11800\end{array}$ & $\begin{array}{l}11000 \\
10200\end{array}$ & $\begin{array}{c}10000 \\
9000\end{array}$ & $\mathrm{n} / \mathrm{a}$ & $\mathrm{n} / \mathrm{a}$ \\
\hline $63.81 \mathrm{R}$ & $\begin{array}{l}13000 ; \\
12200\end{array}$ & $\begin{array}{l}11500 \\
11000\end{array}$ & $\begin{array}{l}10600 ; \\
10100\end{array}$ & $\begin{array}{c}10100 ; \\
9800\end{array}$ & $\begin{array}{l}9800 \\
9000\end{array}$ & $\begin{array}{l}9500 \\
9000\end{array}$ & $\mathrm{n} / \mathrm{a}$ & $\mathrm{n} / \mathrm{a}$ & $\mathrm{n} / \mathrm{a}$ & $\mathrm{n} / \mathrm{a}$ \\
\hline $64.29 \mathrm{R}$ & $\begin{array}{l}15200 ; \\
14000\end{array}$ & $\begin{array}{l}14000 \\
13800\end{array}$ & $\begin{array}{l}14000 ; \\
13800\end{array}$ & $\begin{array}{l}12500 ; \\
11900\end{array}$ & $\begin{array}{l}11900 ; \\
11600\end{array}$ & $\begin{array}{l}12000 ; \\
11500\end{array}$ & $\begin{array}{l}10500 ; \\
10000\end{array}$ & $\begin{array}{c}10200 \\
9000\end{array}$ & $\begin{array}{c}10200 \\
9000\end{array}$ & $\begin{array}{c}10200, \\
9000\end{array}$ \\
\hline $65.10 \mathrm{~L}$ & $\begin{array}{l}14500 ; \\
13200\end{array}$ & $\begin{array}{l}13500 \\
11500\end{array}$ & $\begin{array}{l}12200 ; \\
11900\end{array}$ & $\begin{array}{c}11300 ; \\
9900\end{array}$ & $\begin{array}{l}9600 \\
9000\end{array}$ & $\mathrm{n} / \mathrm{a}$ & $\mathrm{n} / \mathrm{a}$ & $\mathrm{n} / \mathrm{a}$ & $\mathrm{n} / \mathrm{a}$ & $\mathrm{n} / \mathrm{a}$ \\
\hline $65.78 \mathrm{~L}$ & $\begin{array}{l}14000 ; \\
11600\end{array}$ & $\begin{array}{c}10100 \\
9500 \\
\end{array}$ & $\begin{array}{l}9500 \\
9000\end{array}$ & $\begin{array}{l}9500 ; \\
9000\end{array}$ & $\begin{array}{l}9500 ; \\
9000\end{array}$ & $\begin{array}{l}9500 ; \\
9000\end{array}$ & $\begin{array}{l}9500 ; \\
9000\end{array}$ & $\begin{array}{l}9500 ; \\
9000\end{array}$ & $\begin{array}{l}9500 ; \\
9000\end{array}$ & $\begin{array}{l}9500 ; \\
9000\end{array}$ \\
\hline August & 0 & 1 & 2 & 3 & 4 & 5 & 6 & 7 & 8 & 9 \\
\hline $63.33 \mathrm{R}$ & $\begin{array}{l}14500 ; \\
14300\end{array}$ & $\begin{array}{l}13100 \\
11700\end{array}$ & $\begin{array}{c}11000 \\
9500\end{array}$ & $\begin{array}{l}9200 \\
8450\end{array}$ & $\begin{array}{l}8600 \\
8430\end{array}$ & $\begin{array}{l}8430 \\
8420\end{array}$ & $\mathrm{n} / \mathrm{a}$ & $\mathrm{n} / \mathrm{a}$ & $\mathrm{n} / \mathrm{a}$ & $\mathrm{n} / \mathrm{a}$ \\
\hline $63.56 \mathrm{R}$ & $\begin{array}{l}15500 \\
14900\end{array}$ & $\begin{array}{l}14600 \\
13800\end{array}$ & $\begin{array}{l}13400 ; \\
12800\end{array}$ & $\begin{array}{l}12300 ; \\
11500\end{array}$ & $\begin{array}{l}11000 ; \\
10200\end{array}$ & $\begin{array}{l}9900 ; \\
9500\end{array}$ & $\begin{array}{l}9500 ; \\
8400\end{array}$ & $\mathrm{n} / \mathrm{a}$ & $\mathrm{n} / \mathrm{a}$ & $\mathrm{n} / \mathrm{a}$ \\
\hline $63.81 \mathrm{R}$ & $\begin{array}{l}14400 \\
13000\end{array}$ & $\begin{array}{l}13400 \\
12400\end{array}$ & $\begin{array}{l}12400 ; \\
11700 \\
\end{array}$ & $\begin{array}{l}12400 ; \\
11700\end{array}$ & $\begin{array}{l}11500 ; \\
10600\end{array}$ & $\begin{array}{c}10300 \\
9800\end{array}$ & $\mathrm{n} / \mathrm{a}$ & $\mathrm{n} / \mathrm{a}$ & $\mathrm{n} / \mathrm{a}$ & $\mathrm{n} / \mathrm{a}$ \\
\hline $64.29 R$ & $\begin{array}{l}15800 ; \\
14800\end{array}$ & $\begin{array}{r}1260 \\
11000 \\
\end{array}$ & $\begin{array}{l}10600 ; \\
10200\end{array}$ & $\begin{array}{l}9500 ; \\
9300\end{array}$ & $\begin{array}{l}9500 \\
8400\end{array}$ & $\begin{array}{l}8300 \\
8100\end{array}$ & $\begin{array}{l}8300 ; \\
8100\end{array}$ & $\mathrm{n} / \mathrm{a}$ & $\mathrm{n} / \mathrm{a}$ & $\mathrm{n} / \mathrm{a}$ \\
\hline $65.10 \mathrm{~L}$ & $\begin{array}{l}13700 ; \\
13100 \\
\end{array}$ & $\begin{array}{l}11000 \\
10400\end{array}$ & $\begin{array}{c}10200 \\
8500 \\
\end{array}$ & $\begin{array}{l}8500 ; \\
8300\end{array}$ & $\begin{array}{l}8300 ; \\
8100\end{array}$ & $\mathrm{n} / \mathrm{a}$ & $\mathrm{n} / \mathrm{a}$ & $\mathrm{n} / \mathrm{a}$ & $\mathrm{n} / \mathrm{a}$ & $\mathrm{n} / \mathrm{a}$ \\
\hline $65.70 \mathrm{~L}$ & $\begin{array}{l}17000 ; \\
16000\end{array}$ & $\begin{array}{l}15300 \\
13700\end{array}$ & $\begin{array}{l}13200 ; \\
10200\end{array}$ & $\begin{array}{c}10000 \\
9800\end{array}$ & $\begin{array}{l}9800 ; \\
9600\end{array}$ & $\begin{array}{l}9500 \\
8100\end{array}$ & $\mathrm{n} / \mathrm{a}$ & $\mathrm{n} / \mathrm{a}$ & $\mathrm{n} / \mathrm{a}$ & $\mathrm{n} / \mathrm{a}$ \\
\hline $65.78 \mathrm{~L}$ & $\begin{array}{l}12000 ; \\
10800\end{array}$ & $\begin{array}{l}10700 \\
10300\end{array}$ & $\begin{array}{l}9600 \\
9400\end{array}$ & $\begin{array}{l}9400 \\
8400\end{array}$ & $\begin{array}{l}8300 ; \\
8100\end{array}$ & $\mathrm{n} / \mathrm{a}$ & $\mathrm{n} / \mathrm{a}$ & $\mathrm{n} / \mathrm{a}$ & $\mathrm{n} / \mathrm{a}$ & $\mathrm{n} / \mathrm{a}$ \\
\hline
\end{tabular}
data were filtered out due to uncertainty. Filtering during steady flow (September and October intervals) was manually examined; discharge did not vary enough to warrant gross filtering]

Data from the intervals surrounding change from fluctuating to steady flow (in August and September) were compared using the stable readings from August (the instruments beyond the transient shoreline) and the instruments from September with corresponding depths (the nearest-shore units), at the same times of day. These data were used to compare persistent thermal gradients between the two flow regimes. 


\section{Results}

All filtered data are contained in appendix B. All intervals of filtered data (July, August, September, and October) were examined for magnitudes of temperature differences, patterns of change relative to shoreline characteristics, and change relative to insolation, air temperature, and flow regime (appendix $\mathrm{C}$ and fig. 13). Averages of these metrics for each interval give an overview of results (table 4). Mean temperature gradients range from 0.0 to $0.1^{\circ} \mathrm{C} / \mathrm{m}$ during all periods. Maximum and minimum temperature gradients range from -0.2 to $2.6^{\circ} \mathrm{C} / \mathrm{m}$ in July and August to -0.2 to $5.4^{\circ} \mathrm{C} / \mathrm{m}$ in October. September displays the smallest magnitude of thermal gradients, with a minimum of $-0.3{ }^{\circ} \mathrm{C} / \mathrm{m}$ and a maximum value of $0.5^{\circ} \mathrm{C} / \mathrm{m}$.

Table 4. Summary of discharge characteristics, dam release and mainstem water temperatures, air temperatures, and nearshore temperature gradients for each study interval.

\begin{tabular}{|c|c|c|c|c|}
\hline & July & August & September & October \\
\hline Flow regime & Fluctuating & Fluctuating & Steady & Steady \\
\hline \multicolumn{5}{|l|}{ Mainstem temperature $\left({ }^{\circ} \mathrm{C}\right)$} \\
\hline Mean & 12.8 & 12.8 & 13.4 & 12.2 \\
\hline $\operatorname{Max}$ & 13.9 & 14 & 15 & 14.1 \\
\hline Min & 11.7 & 11.8 & 12.2 & 10.8 \\
\hline \multicolumn{5}{|l|}{ Air temperature $\left({ }^{\circ} \mathrm{C}\right)$} \\
\hline Mean & 34.7 & 30.8 & 28.7 & 18.4 \\
\hline $\operatorname{Max}$ & 45.6 & 42.1 & 41.9 & 27.2 \\
\hline Min & 22 & 17.1 & 16.8 & 9.7 \\
\hline \multicolumn{5}{|l|}{ Discharge $\left(\mathrm{ft}^{3} / \mathrm{s}\right)$} \\
\hline Mean & 13767 & 14862 & 8819 & 8572 \\
\hline $\operatorname{Max}$ & 18211 & 22847 & 15385 & 15658 \\
\hline Min & 9253 & 9334 & 8198 & 8173 \\
\hline Discharge range $\left(\mathrm{ft}^{3} / \mathrm{s}\right)$ & 8958 & 13513 & 7187 & 7485 \\
\hline \multicolumn{5}{|l|}{$\begin{array}{l}\text { Dam release temperature } \\
\qquad\left({ }^{\circ} \mathrm{C}\right)^{i}\end{array}$} \\
\hline Mean & 10.3 & 10.6 & 11.1 & 10.9 \\
\hline $\operatorname{Max}$ & 11.4 & 11.7 & 11.8 & 11.7 \\
\hline Min & 9.3 & 9.4 & 10 & 9.6 \\
\hline \multicolumn{5}{|l|}{$\begin{array}{c}\text { Temperature gradient } \\
\left({ }^{\circ} \mathrm{C} / \mathrm{m}\right)\end{array}$} \\
\hline Mean & 0.1 & 0.1 & 0 & 0.1 \\
\hline Mean AM & 0 & 0.5 & 0 & 0.1 \\
\hline Mean PM & 0.1 & 0.7 & 0 & 0.2 \\
\hline $\operatorname{Max}$ & 2.6 & 2.3 & 0.5 & 3.1 \\
\hline Max AM & 0.8 & 2.3 & 0.4 & 2.8 \\
\hline Max PM & 2.6 & 1.7 & 0.5 & 3.1 \\
\hline Min & -0.2 & -0.7 & -0.3 & -2 \\
\hline Min AM & -0.1 & -0.7 & -0.2 & -2 \\
\hline Min PM & -0.2 & -0.5 & -0.3 & -1.1 \\
\hline
\end{tabular}

${ }^{\mathrm{i}}$ Nancy Hornewer, written commun., 2011 
Average difference between shoreline and mainstem temperature, July 2010

$=63.65=63.81=64.29=65.1 \pm 65.78$

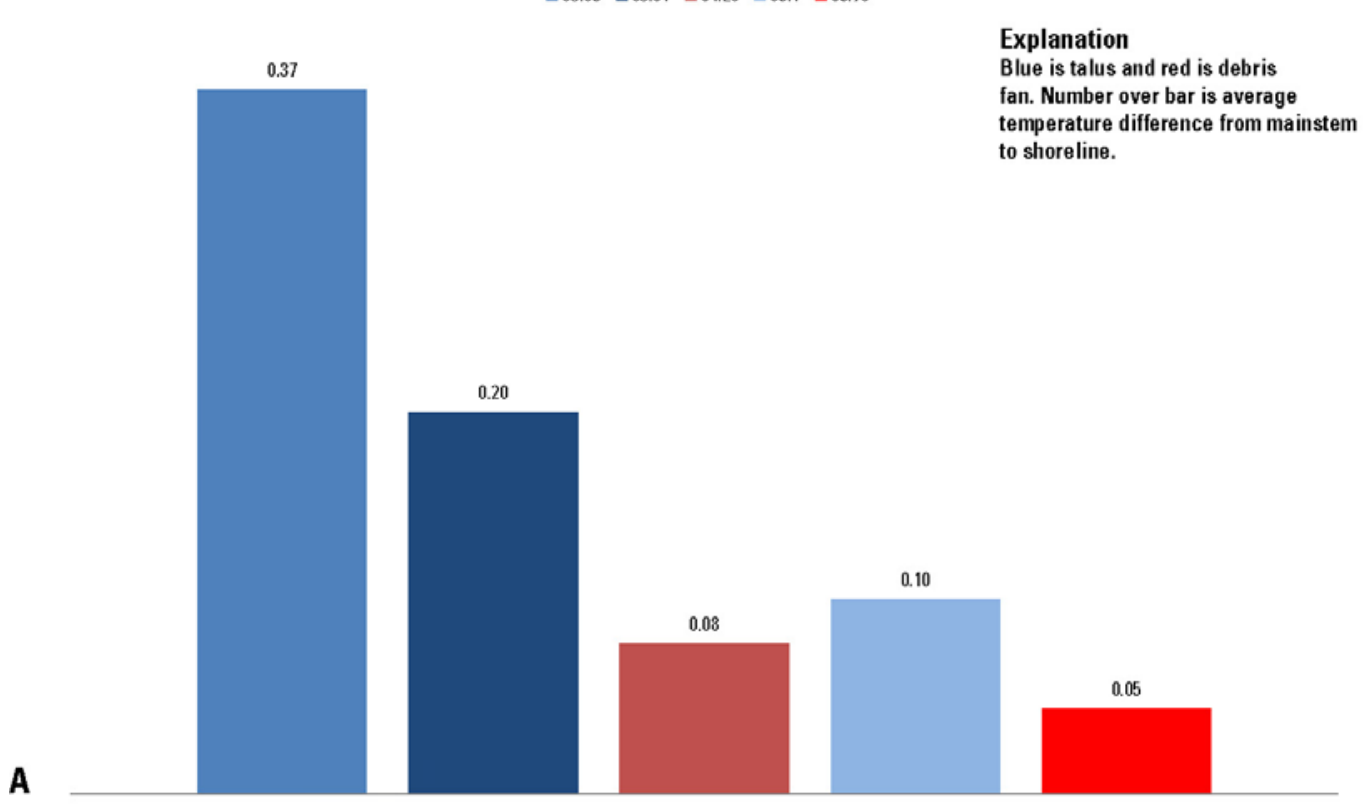

Average difference between shoreline and mainstem temperatures, August 2010

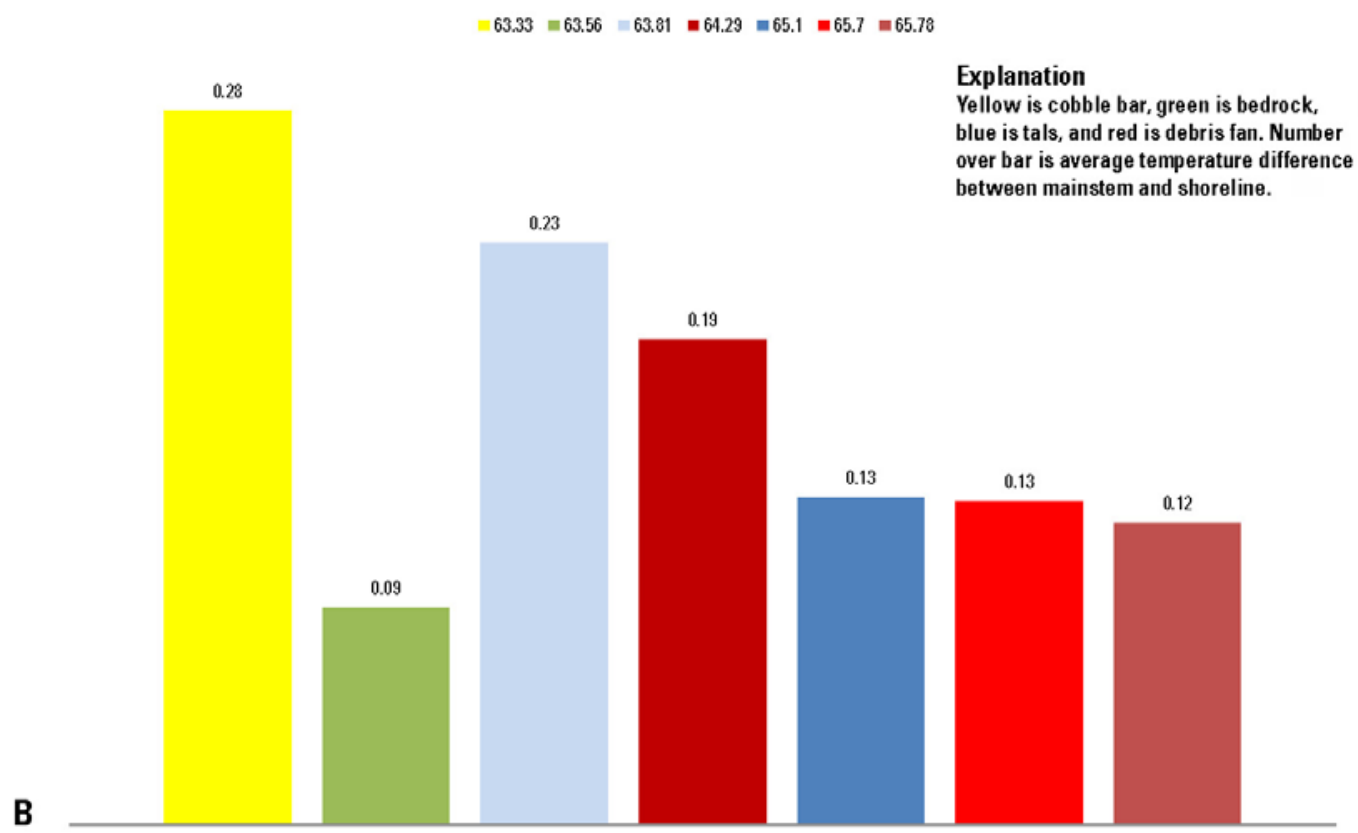


Average difference between shoreline and mainstem temperatures, September 2010

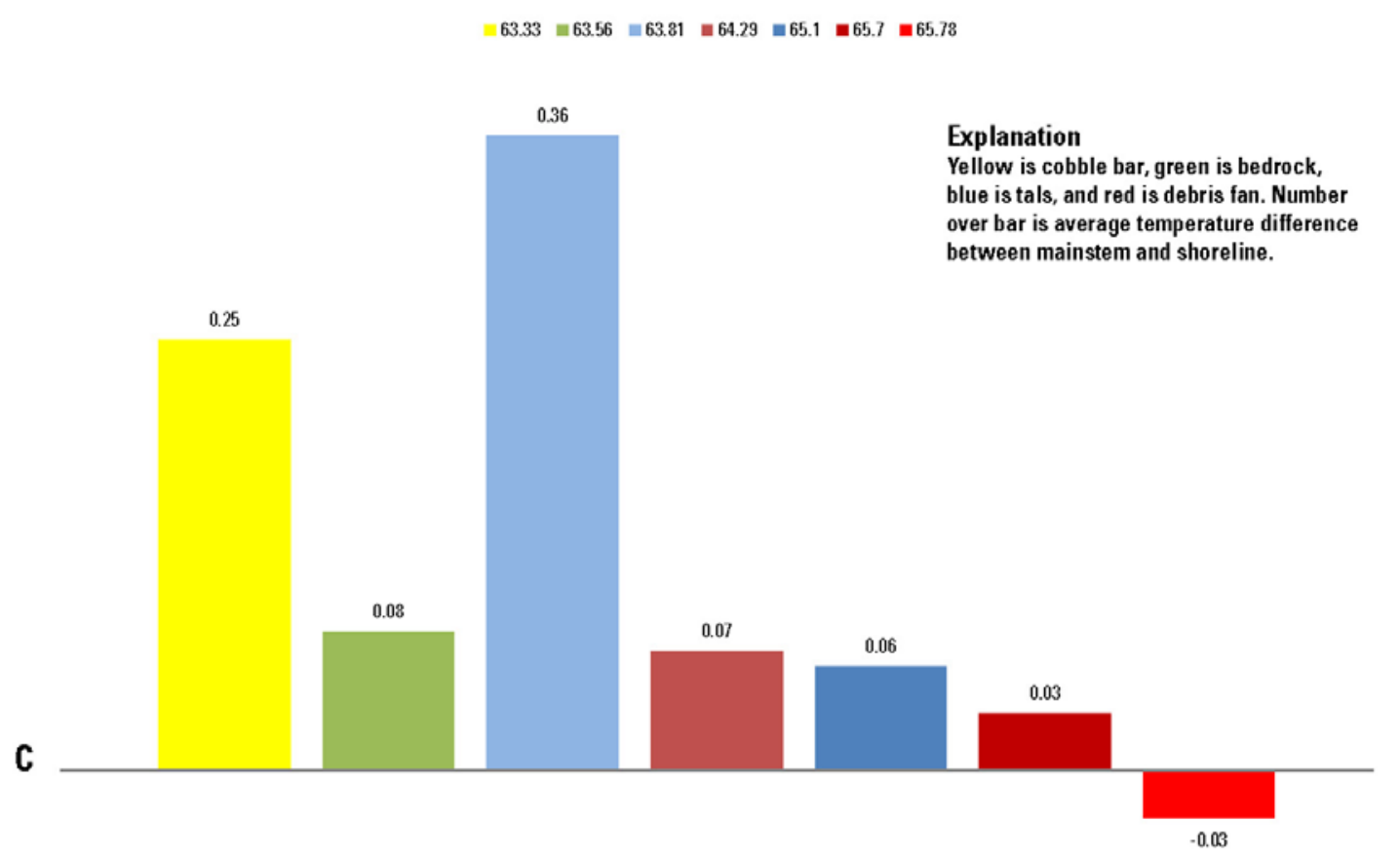

Average difference between shoreline and mainstem temperatures, 0ctober 2010

$63.33=63.56=63.81=64.29=64.292 \square 65.1 \quad \square 65.7 \quad 65.73$

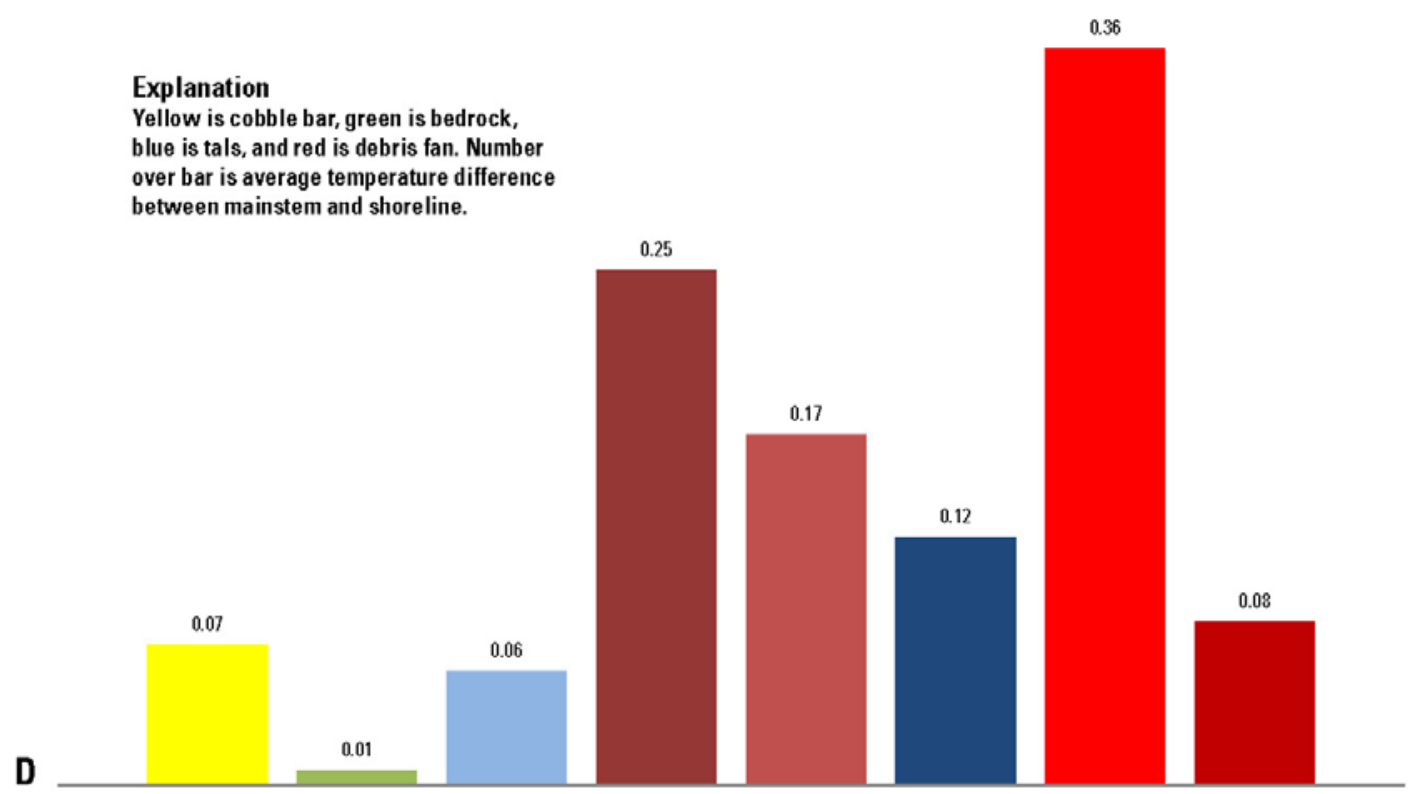

Figure 13. Average temperature differences from mainstem to shoreline for all study intervals, shown by bar height and numerical value. Columns are color-coded by shoreline type, where yellow is cobble bar/island, green is bedrock, blue is talus, and red is debris fan. 
Temperature gradients from the mainstem to within $0.5 \mathrm{~m}$ of the first submerged thermistor were much less than $1^{\circ} \mathrm{C}$ across all monitoring periods (fig. 14). However, significant gradients between the first submerged thermistor and the next thermistor towards the mainstem were observed during the discharge upramp and downramp phases of fluctuating flows. These differences are most likely related to the different placement of thermistors during fluctuating flows and steady flows rather than differences in thermal gradients between the flow regimes. During steady flows, the thermistor nearest the shoreline was always $0.5 \mathrm{~m}$ or more from the shoreline. During fluctuating flows, thermistors were sometimes nearer to the shoreline yet still submerged. Thus, during fluctuating flows, we sampled shallower water nearer the shoreline. The magnitude of the observed temperature difference between the two nearshore thermistors is greatest during the afternoon decrease in discharge, when air temperatures and insolation are the highest and are more pronounced (fig. 14). Air temperature and discharge are the main external controls on shoreline water temperature, and effects of insolation are reduced as the sun moves behind the canyon rim; this can be seen in July and August 2010 three-day subintervals for site RM 65.10L, which show a greater gradient during late afternoon hours when air temperature is higher (fig. 14).

Because the sampling environments between fluctuating and steady flows were different, six sites were evaluated for temperature differences and gradients, using only the thermistors that were constantly submerged (those still submerged during the lowest discharge) for all flows. This provides a comparison between flow regimes based on the same number of thermistors. The August fluctuating flow interval and the September steady flow interval were chosen for the comparison because air temperature and degree of insolation were similar, with the only marked variables being flow regime and release temperature from Glen Canyon Dam. The comparison shows that the temperature difference from the mainstem thermistors to the first consistently submerged thermistor is less than the accuracy of the instruments for both the fluctuating and steady-flow regimes (fig. 15).

Thermal gradients of significant values are more abundant in both frequency and magnitude during the July, August, and October intervals than in the September interval (figs. 16 and 17). Frequency of site-averaged thermal differences above the accuracy level of the thermistors $\left(0.2^{\circ} \mathrm{C}\right)$ ranges from 0 to 40 percent of the time in July, 10-20 percent of the time in August, 0-15 percent of the time in September, and and 5-20 percent of the time in October (fig. 17). Temperature differences of approximately $4{ }^{\circ} \mathrm{C}$ are deemed significant to fish behavior over short time periods of 4-6 hours (T.A. Kennedy, oral commun., 2011) Thermal differences of these magnitudes were not observed for any time periods more than 2 hours and were generally much more short-lived.

We did not observe consistent differences in mainstem-to-shoreline temperature gradients among the four shoreline types that were monitored (fig. 13). One of the debris-fan shoreline sites (RM 65.78L) tended to have the lowest temperature gradients, but other debris fan sites had gradients similar to the other shoreline types. The debris fan at RM 65.78L is located near a persistent backwater and is on the downstream end of an eddy that is prone to rapid deposition, as was evidenced by the formation of an extensive offshore reattachment bar in August 2010. 

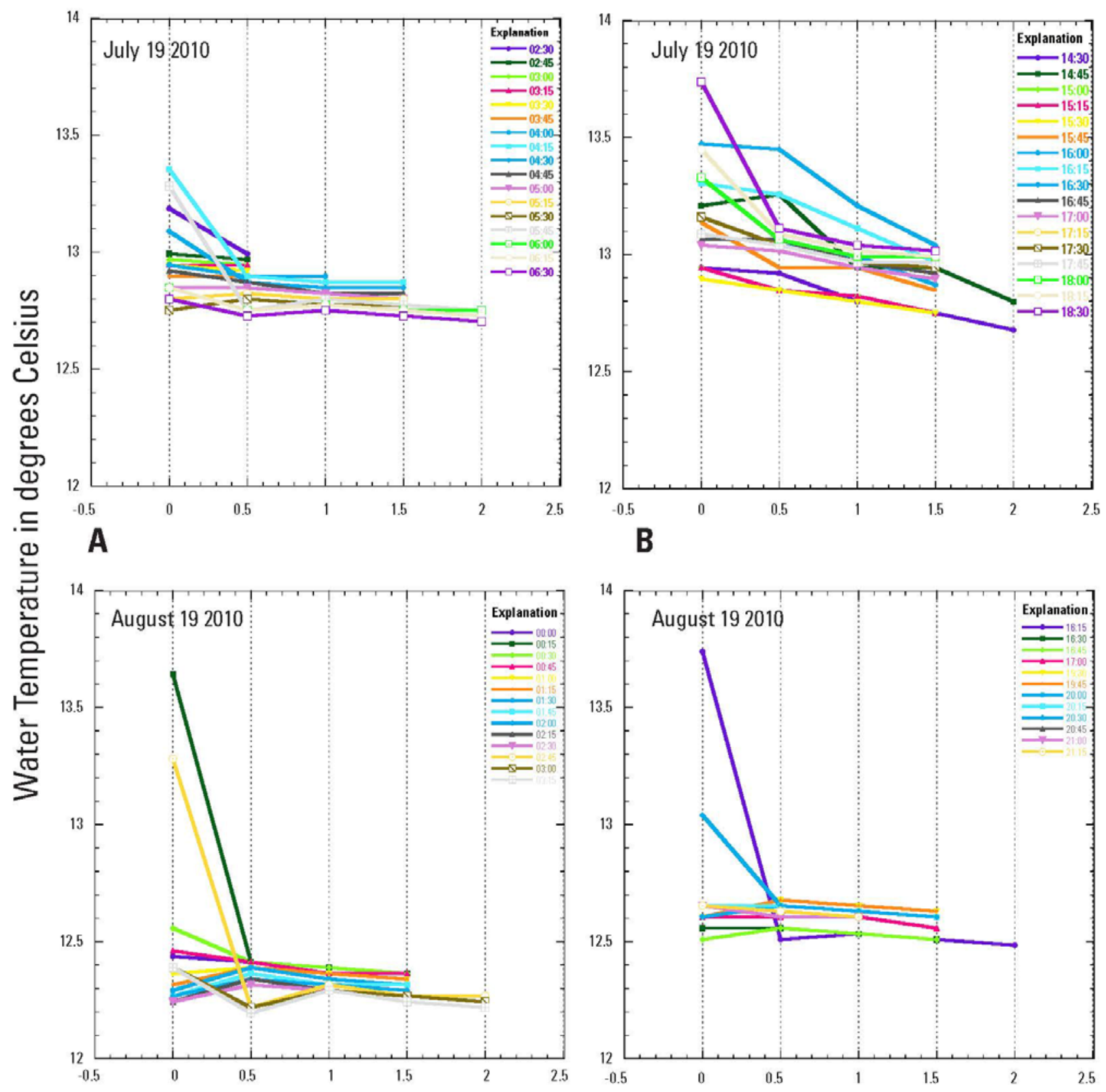

C

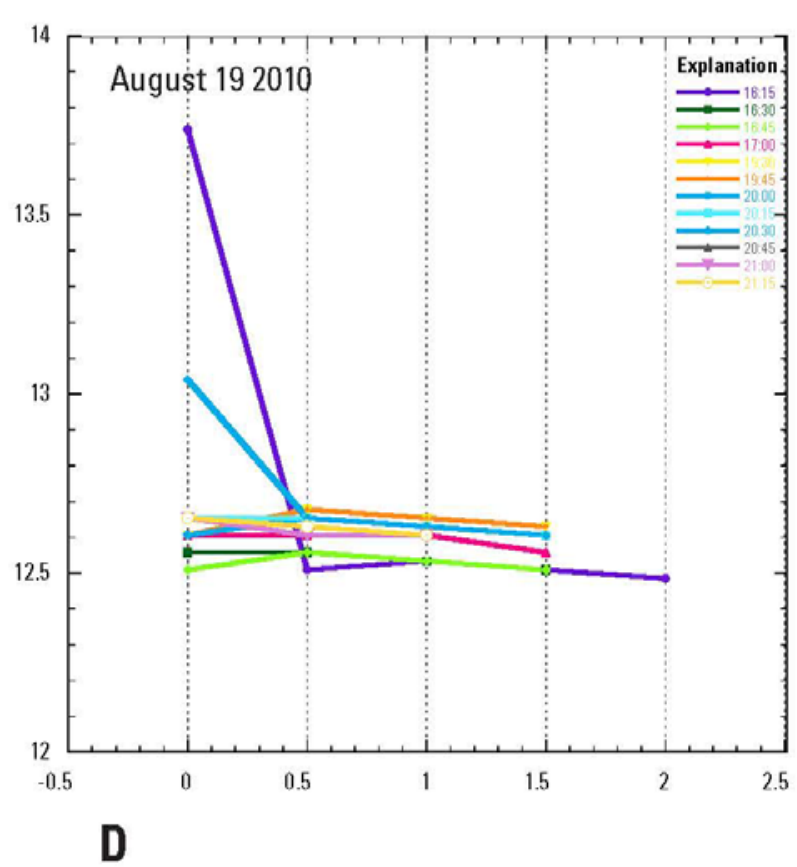

Distance from shoreline in meters 

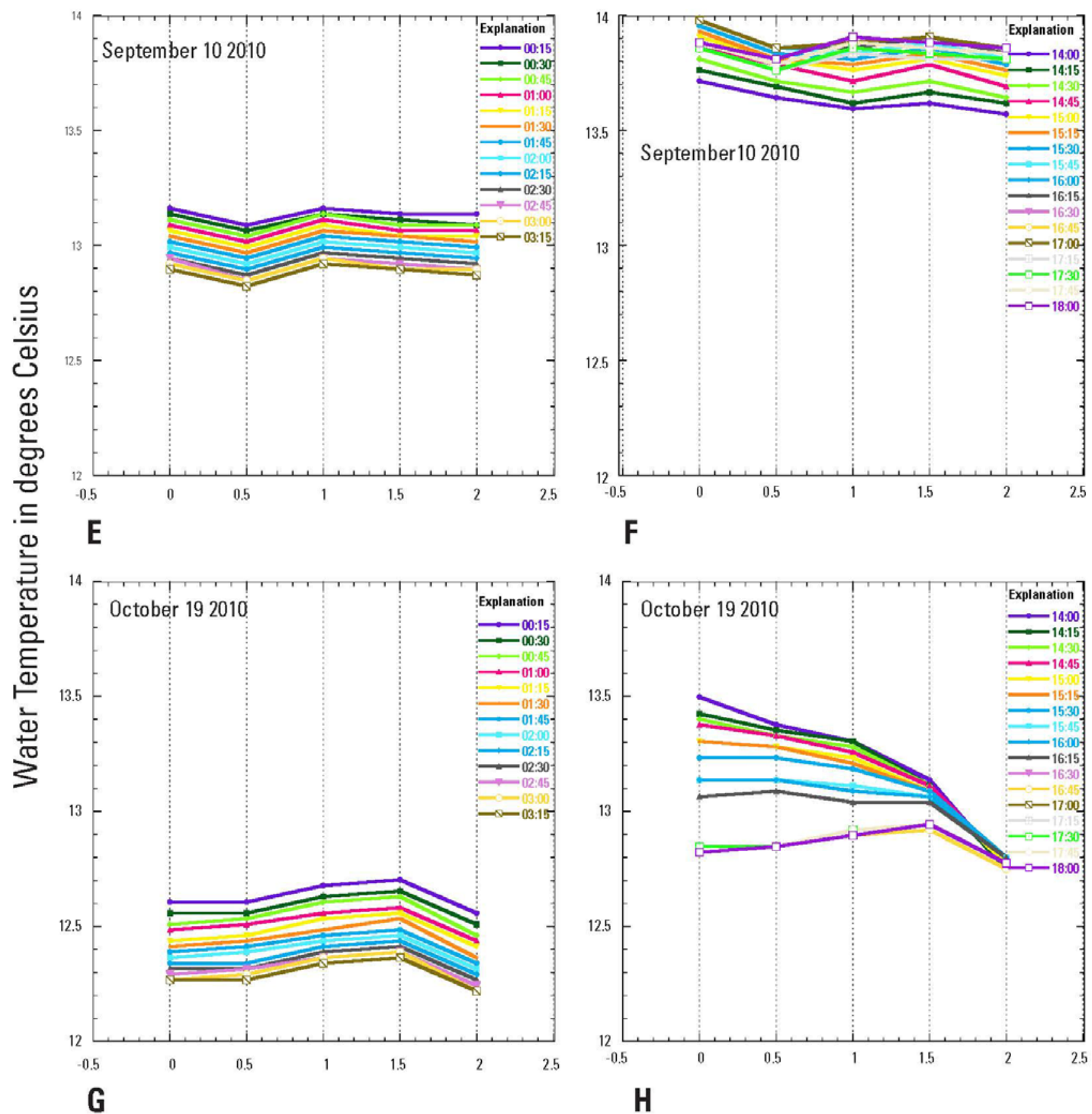

\section{Distance from shoreline in meters}


Figure 14. Examples of nearshore temperatures during fluctuating flows in July and August $2010(A-D)$, and September and October $2010(E-H)$. Temperatures are shown at site RM 65.10L for July 19, 2010, during the early morning increase in discharge $(A)$ and late afternoon decrease in discharge $(B)$, and for August 19 , 2010, during early morning increase in discharge $(C)$ and late afternoon decrease in discharge $(D)$. Temperatures are shown at site RM 65.10L for September 10, 2010, during early morning $(E)$ and late afternoon $(F)$, and for October 19, 2010, during early morning $(G)$ and late afternoon $(H)$. These time periods are similar to the periods of increases and decreases in discharge examined for July and August during fluctuating flow. Vertical scales are water temperature in degrees Celsius, and are set at a common scale for all plots. Horizontal scale is distance from effective shoreline in meters, defined as the point where the first submerged thermistor is located. This point does not change in the intervals presented for the two periods of steady flow. In fluctuating flows, significant increases in temperature relative to the rest of the line exist for the thermistors nearest to shore. Note that periods of significant increase in temperature are limited to very short time periods, often in the range of 15 minutes to 1 hour. In both instances examined during steady flow, there is no observed thermal gradient near the shore, although there is an increase in overall water temperature during the afternoon interval for September, and a possible thermal gradient in the afternoon interval for October. This temperature difference from mainstem to nearshore in October is short-lived (less than $0.7^{\circ} \mathrm{C}$ over 2 hours). Each series is a simultaneous reading of all thermistors on the line; the legend in the upper right corner indicates the time of measurement for each series. 


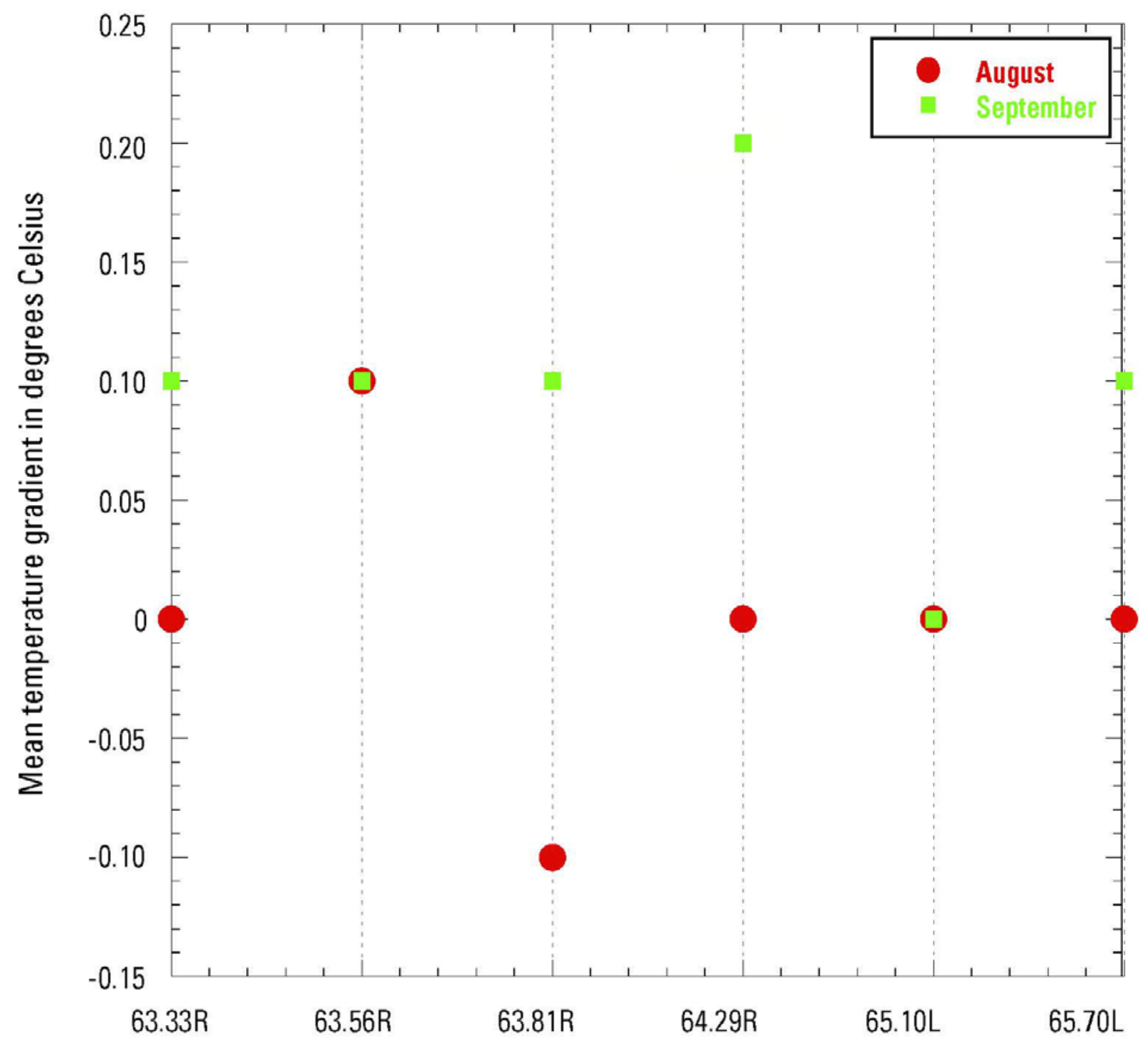

Site

Figure 15. Comparison of constantly submerged thermistors during fluctuating flows (August) to similarly placed thermistors during steady flows (September). The comparison is inconclusive; all pairs are within $0.2^{\circ} \mathrm{C}$ of each other and therefore are insignificant relative to the accuracy of the data loggers $\left(0.2^{\circ} \mathrm{C}\right)$. 


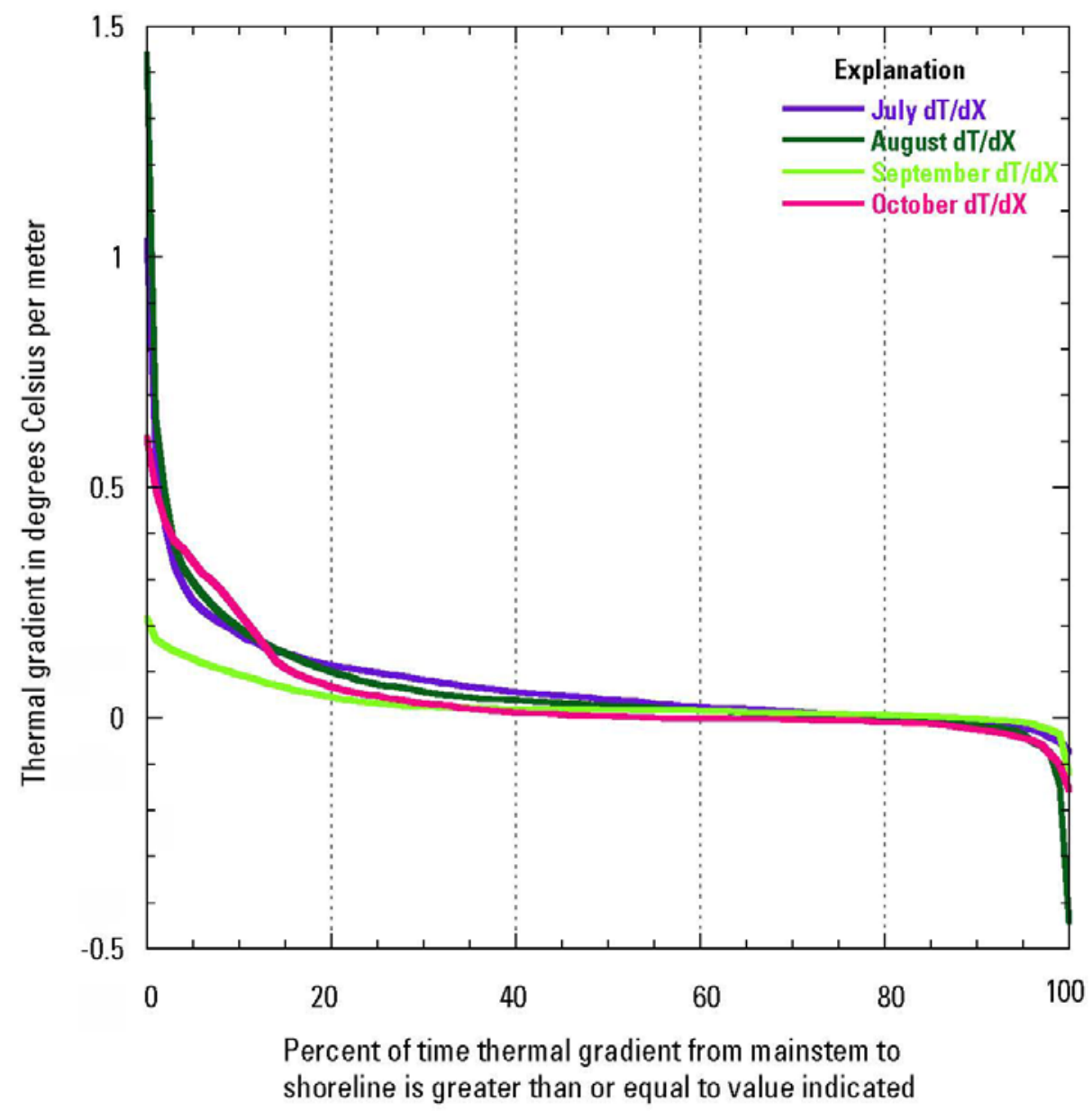

Figure 16. Cumulative frequency distributions showing the fraction of time the thermal gradient from mainstem to shoreline is greater than or equal to value indicated. Plotted data are average values of all sites for each measurement interval. For example, in July the observed thermal gradient is greater than or equal to -0.1 ${ }^{\circ} \mathrm{C} / \mathrm{m} 100$ percent of the time interval and greater than or equal to $1.1^{\circ} \mathrm{C} / \mathrm{m} 0$ percent of the time. All intervals display thermal gradients in excess of the accuracy of the HOBO thermistors $\left(\sim 0.2^{\circ} \mathrm{C}\right)$ less than 15 percent of the time. Maximum thermal gradients approach $1-1.5^{\circ} \mathrm{C} / \mathrm{m}$ during July and August fluctuating flows, and $0.2-0.6^{\circ} \mathrm{C} / \mathrm{m}$ in September and October steady flows. 

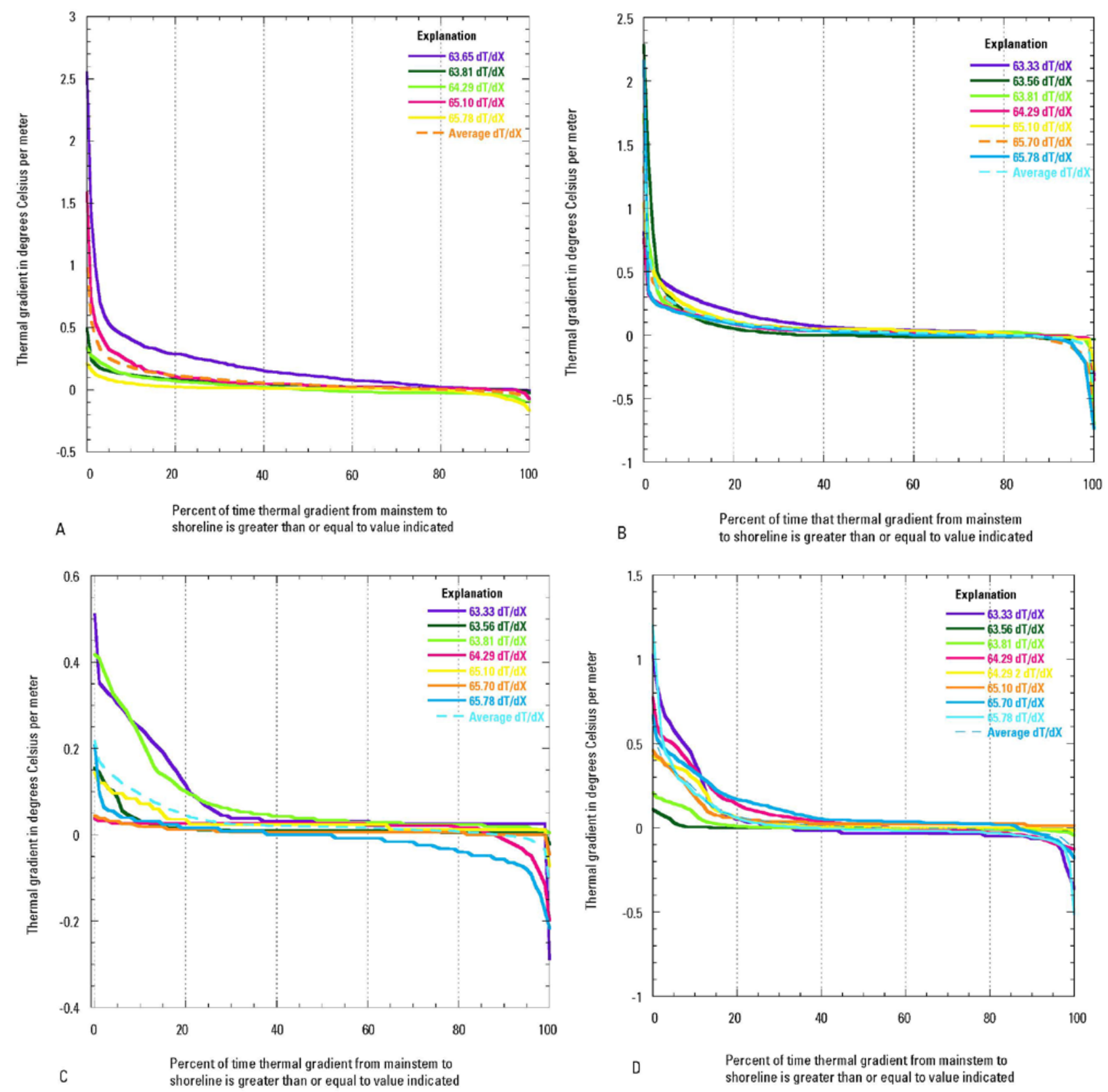

Figure 17. Cumulative temperature frequency distribution for all study intervals. $A$, Cumulative frequency distribution for all study sites in July 2010. Plotted data are magnitudes of thermal gradient from mainstem to shoreline in degrees Celsius per meter against percentage of time during interval that gradient is greater than or equal to value shown; for example, at site RM 63.65R (purple series), observed thermal gradient is greater than or equal to $0.0^{\circ} \mathrm{C} / \mathrm{m} 100$ percent of the time interval and greater than or equal to $2.6^{\circ} \mathrm{C} / \mathrm{m} 0$ percent of the time. In general, thermal gradients greater than the tolerances of the Onset HOBO Pro v2 $\left(\sim 0.2^{\circ} \mathrm{C}\right)$ are observed in the frequency interval of 0-15 percent, with RM 63.65R reaching significant gradient (more than $0.2^{\circ} \mathrm{C} / \mathrm{m}$ ) up to 40 percent of the study interval period. Dashed orange line represents the averaged value of data for all sites, with temperature differences greater than $0.2^{\circ} \mathrm{C}$ occurring 0 to 10 percent of the time. Thermal differences for all sites in excess of $1{ }^{\circ} \mathrm{C}$ occur 5 percent of the time or less. 
$B$, Cumulative frequency distribution of absolute temperature differences for all study sites in August 2010. Plotted data are magnitudes of thermal gradient from mainstem to shoreline, in degrees Celsius per meter against percent of time during interval that gradient is greater than or equal to value shown; for example, at site RM 63.33R (purple series), observed thermal gradient is greater than or equal to $-0.4^{\circ} \mathrm{C} / \mathrm{m} 100$ percent of the time interval, and greater than or equal to $1.0^{\circ} \mathrm{C} / \mathrm{m} 0$ percent of the time. In general, thermal gradients greater than the tolerances of the Onset HOBO Pro v2 $\left(\sim 0.2^{\circ} \mathrm{C}\right)$ are observed in the frequency interval of 0 10 percent, with site RM $63.33 \mathrm{R}$ reaching significant gradient up to 20 percent of the study interval period. C. Cumulative frequency distribution for all study sites in September 2010. Plotted data are magnitudes of thermal gradient from mainstem to shoreline in degrees Celsius per meter against percent of time during interval that gradient is greater than or equal to value shown; for example, for RM 63.81R (light green series), observed thermal gradient is greater than or equal to $0{ }^{\circ} \mathrm{C} / \mathrm{m} 100$ percent of the time interval, and greater than or equal to $0.4^{\circ} \mathrm{C} / \mathrm{m} 0$ percent of the time. For five of the seven sites, thermal gradients greater than the accuracy of the Onset HOBO Pro v2 $\left(\sim 0.2^{\circ} \mathrm{C}\right)$ are not observed, with sites RM 63.81R and RM 63.33R reaching significant gradient up to 15 percent of the study interval period. Dashed aquamarine line represents the averaged value of all data at all sites, with significant gradient not observed. No thermal gradients in excess of $1{ }^{\circ} \mathrm{C} / \mathrm{m}$ were observed. Site RM $65.78 \mathrm{~L}$ displayed cooling from mainstem to near shore during a significant part of the study interval, likely due to the formation of an offshore sandbar in early September. $D$, Cumulative frequency distribution for all study sites in October 2010. Plotted data are magnitudes of thermal gradients from mainstem to shoreline in degrees Celsius per meter against percent of time during interval that gradient is greater than or equal to value shown; for example, at site RM 64.29R (fuchsia series), observed thermal gradient is greater than or equal to $-0.2{ }^{\circ} \mathrm{C} / \mathrm{m} 100$ percent of the time interval and greater than or equal to $0.8^{\circ} \mathrm{C} / \mathrm{m} 0$ percent of the time. In general, thermal gradients greater than the tolerances of the Onset HOBO Pro v2 $\left(\sim 0.2^{\circ} \mathrm{C}\right)$ are observed in the frequency interval $0-15$ percent of the time. Dashed aquamarine line represents the averaged value of all data for all sites, with significant gradient observed overall in the $0-12$ percent frequency interval. Thermal gradients in excess of $1{ }^{\circ} \mathrm{C} / \mathrm{m}$ are only observed for sites RM $64.33 \mathrm{R}$ and $65.78 \mathrm{~L}$ and are negligible (less than 2 percent frequency). Note that site RM 65.78L still displays some cooling from mainstem to near shore, but to a much lesser extent than observed in September, likely due to erosion of the offshore sandbar noted after the transition from fluctuating to steady flow.

The rapid decrease in channel depth led to erratic temperature measurements, as the offshore sandbar created a partial barrier to the mainstem system. A significant temperature change was observed during fluctuating flows, with maximum rates of change between 0.2 and $2.6{ }^{\circ} \mathrm{C} / \mathrm{m}$ (fig. 18). This is caused by flow fluctuation moving the actual shoreline to the initial submerged thermistor, and is ephemeral in nature. There was no pattern between shoreline types within the accuracy of the thermistors, and temperature differences were not significant within the bounds of instrument tolerance for any of the sites.

\section{Discussion}

None of the study locations detected a persistent thermal difference greater than the accuracy of the instruments used for monitoring (within about $0.2^{\circ} \mathrm{C}$ ). More importantly, temperature differences of $4{ }^{\circ} \mathrm{C}$, believed to be important to the habitat-seeking behavior of native or nonnative fishes, were not detected. However, we did observe an ephemeral temperature gradient during times of transition between high and low fluctuating flows, with rates of change possibly approaching $2.5^{\circ} \mathrm{C}$ over a distance of $1 \mathrm{~m}$ (fig. 18). These gradients are likely an artifact of the sampling method during fluctuating flow, where extremely shallow depths at distances less than $0.5 \mathrm{~m}$ from the shoreline were 


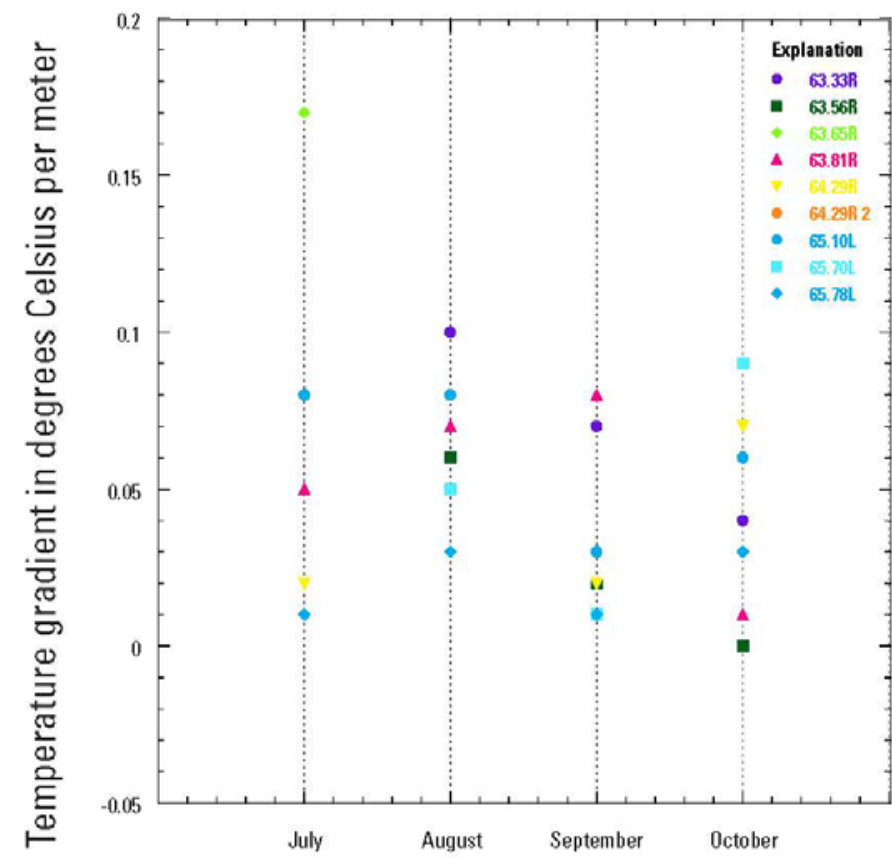

A

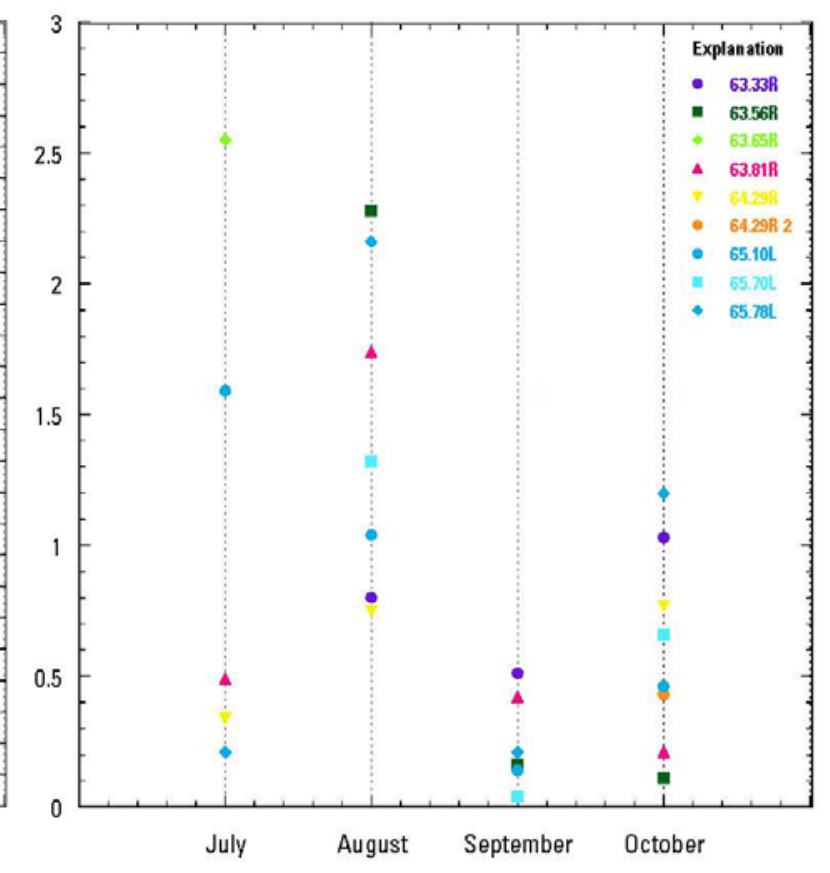

B

\section{Study Interval}

Figure 18. Average $(A)$ and maximum $(B)$ thermal gradients per meter $(\mathrm{dT} / \mathrm{dX})$ for all study sites and measurement intervals. There is no clear pattern in average thermal gradients between study intervals, although maximum thermal gradient values tend to be highest in July and August. The average values for all sites and intervals are less than the accuracy of the instruments $\left(\sim 0.2^{\circ} \mathrm{C}\right)$. Examining thermistors coincident between transient and steady flow periods (the consistently submerged final thermistors in fluctuating flow and the initial thermistors in steady flow) showed no significant thermal gradient between study intervals.

sampled. This type of gradient may be present in steady flows as well, but was not measured because thermistors were never closer than $0.5 \mathrm{~m}$ from the shoreline.

The temperature gradients in this zone within $0.5 \mathrm{~m}$ of the shoreline only occur for short durations, typically less than 2 hours at a time. The frequency and magnitude of these periods of nearshore warming are dependent in part on differences in sampling methods between steady flows and fluctuating flows. At the point where the thermistors nearest to shore are almost subaerial, they are sampling temperature in a much smaller volume of water, where air temperature and insolation have a greater effect on water temperature.

We believe that the temperature data represent changes in flow regime where the thermistor is just submerged in a small volume of water as flow increases or decreases, capturing the highest variability of temperature at the shoreline. However, further work should be undertaken to confirm that these measurements are accurate. This would require that a technician be physically present at each site for the transition periods, noting the exact times that thermistors become subaerial. When results of study intervals during fluctuating flows from August 2010 are compared to results during September steady flows, the temperature gradients from consistently submerged thermistors during the fluctuating 
flows are not substantially different from those during steady flows (fig. 15). Detailed survey of each shoreline would create a local stage-discharge relationship and better constrain the modeled discharge results from CRFS.

\section{References cited}

Dodrill, M.J., 2012, Habitat relationships of small-bodied fish in the Grand Canyon reach of the Colorado River, Arizona-Emphasis on native fish and evaluation of backwater habitats: M.S. thesis, Gainesville, University of Florida.

Korman, J., Kaplinski, M., and Buszowski, J., 2006, Effects of air and mainstem water temperatures, hydraulic isolation, and fluctuating flows from Glen Canyon Dam on water temperatures in shoreline environments of the Colorado River in Grand Canyon: Ecometric Research Inc., Northern Arizona University, and Namtek Inc., submitted to U.S. Geological Survey, Grand Canyon Monitoring and Research Center, Flagstaff, AZ, cooperative agreement no. 04WRAG00006, Modification 1, $52 \mathrm{p}$.

Topping, D.J., Schmidt, J.C., and Vierra, L.E., 2003, Computation and analysis of the instantaneousdischarge for the Colorado River at Lees Ferry, Arizona-May 8, 1921, through September 30, 2000: U.S. Geological Survey Professional Paper 1677, 118 p.

U.S. Geological Survey, 2006, Colorado mileage system [Spatial database, GIS.BASE_GCMRC_TenthMile] 1st rev. ed.: Grand Canyon Monitoring and Research Center [http://www.gcmrc.gov/dasa/default.aspx, last accessed January 18, 2013.].

Wiele, S.M., and Griffin, E.R., 1997, Modifications to a one-dimensional model of unsteady flow in the Colorado River through the Grand Canyon, Arizona: U.S. Geological Survey Water-Resources Investigations Report 97-4046, 17 p.

Wright, S.A., Anderson, C.R., and Voichick, N., 2009, A simplified water temperature model for the Colorado River below Glen Canyon Dam: River Research and Applications, v. 25, p. 675-686. 
Appendix A. Results of Temperature-accuracy Tests on Thermistors 


\begin{tabular}{|c|c|c|c|c|c|c|c|}
\hline $\begin{array}{c}\text { Serial number } \\
\text { of Onset } \\
\text { Technologies } \\
\text { HOBO Pro v2 } \\
\text { Water } \\
\text { Temperature } \\
\text { Data Logger } \\
\text { thermistors } \\
\end{array}$ & $\begin{array}{l}\text { BUCKET } \\
\text { TEST } \\
\text { difference } \\
\text { from } \\
\text { average } \\
\text { (July } \\
2010) \text { OR } \\
\text { other } \\
\text { results } \\
\end{array}$ & $\begin{array}{l}\text { Source of Results (if not from July } \\
2010 \text { bucket test) }\end{array}$ & $\begin{array}{c}\text { SEPTEMBER } \\
2010 \\
\text { BUCKET } \\
\text { TEST } \\
\text { RESULTS } \\
\text { (positive is } \\
\text { higher than } \\
\text { average, } \\
\text { negative is } \\
\text { lower than } \\
\text { average) }\end{array}$ & $\begin{array}{c}\text { SEPTEMBER } \\
29,2010 \\
\text { BUCKET } \\
\text { TEST } \\
\text { RESULTS } \\
\text { (positive is } \\
\text { higher than } \\
\text { average, } \\
\text { negative is } \\
\text { lower than } \\
\text { average) }\end{array}$ & $\begin{array}{c}\text { FEBRUARY } \\
2011 \\
\text { BUCKET } \\
\text { TEST } \\
\text { RESULTS } \\
\text { (positive is } \\
\text { higher than } \\
\text { average, } \\
\text { negative is } \\
\text { lower than } \\
\text { average) } \\
\end{array}$ & $\begin{array}{c}\text { OTHER } \\
\text { TEST } \\
\text { RESULTS }\end{array}$ & Source of Result \\
\hline 1073436 & & & & -0.064 & -0.058 & & \\
\hline 1098590 & & & 0.040 & & & & \\
\hline 1098591 & $\begin{array}{c}\text { LOW BY } \\
0.12 \\
\end{array}$ & & -0.140 & & & & \\
\hline 1098592 & & & & & -0.066 & & \\
\hline 1098593 & $\begin{array}{l}\text { low by } \\
0.036\end{array}$ & & & & & good & $\mathrm{KA} 100217 \mathrm{H}$ \\
\hline 1098594 & $\begin{array}{c}\text { high by } \\
0.03\end{array}$ & river tests August 2010 & & & & & \\
\hline 1101692 & & & -0.037 & & & & \\
\hline 1101693 & & & & & 0.004 & & \\
\hline 1101696 & $\begin{array}{l}\text { low by } \\
0.012\end{array}$ & & -0.018 & & & & \\
\hline 1101697 & $\begin{array}{l}\text { low by } \\
0.005\end{array}$ & river tests August 2010 & & & & good & $\mathrm{R} 0651002 \mathrm{H}$ \\
\hline 1161792 & $\begin{array}{l}\text { GOOD } \\
(<0.01)\end{array}$ & & -0.043 & & & & \\
\hline 1161793 & $\begin{array}{l}\text { high by } \\
0.035\end{array}$ & river tests August 2010 & & & & good & $\mathrm{R} 0651002 \mathrm{H} 2$ \\
\hline 1161795 & $\begin{array}{l}\text { high by } \\
0.04\end{array}$ & river tests August 2010 & & & & & \\
\hline 1161797 & $\begin{array}{l}\text { low by } \\
0.046\end{array}$ & & -0.019 & & & & \\
\hline 1161798 & $\begin{array}{l}\text { high by } \\
0.046\end{array}$ & & & & & & \\
\hline 1161799 & $\begin{array}{l}\text { high by } \\
0.04\end{array}$ & & -0.006 & & & & \\
\hline 1177166 & $\begin{array}{c}\text { high by } \\
0.029\end{array}$ & river tests August 2010 & & & & & \\
\hline 1177158 & & & & & 0.050 & & \\
\hline 1177159 & $\begin{array}{c}\text { high by } \\
0.04\end{array}$ & river tests August 2010 & & & & & \\
\hline 1177160 & & & & & 0.044 & & \\
\hline 1177164 & & & & & 0.036 & & \\
\hline
\end{tabular}




\begin{tabular}{|c|c|c|c|c|c|c|c|}
\hline 1177167 & $\begin{array}{l}\text { high by } \\
0.042\end{array}$ & & 0.015 & 0.006 & & & \\
\hline 1177169 & & & 0.007 & 0.024 & & & \\
\hline 1177170 & $\begin{array}{l}\text { low by } \\
0.031\end{array}$ & river tests August 2010 & & & & & \\
\hline 1177171 & & & & & 0.032 & & \\
\hline 1177172 & low by 0.3 & river tests August 2010 & & & & & \\
\hline 1177173 & & & & & 0.012 & & \\
\hline 1177233 & & & -0.093 & & -0.240 & & \\
\hline 1177234 & $\begin{array}{l}\text { high by } \\
0.025\end{array}$ & river tests August 2010 & & & & good & $\mathrm{R} 0871002 \mathrm{H}$ \\
\hline 1177235 & $\begin{array}{l}\text { low by } \\
0.031\end{array}$ & & -0.032 & & 0.025 & & \\
\hline 1177236 & $\begin{array}{l}\text { low by } \\
0.01\end{array}$ & river tests August 2010 & & & & & \\
\hline 1177237 & $\begin{array}{c}\text { LOW BY } \\
0.007\end{array}$ & river tests August 2010 & & & & good & $\mathrm{R} 0631002 \mathrm{H}$ \\
\hline 1177239 & $\begin{array}{l}\text { low by } \\
0.019\end{array}$ & river tests August 2010 & & & & good & HA100217H2 \\
\hline 1193202 & $\begin{array}{l}\text { low by } \\
0.085\end{array}$ & & -0.071 & & & & \\
\hline 1193203 & & & -0.006 & -0.010 & & & \\
\hline 1193204 & $\begin{array}{c}\text { high by } \\
0.031\end{array}$ & & -0.004 & & 0.029 & $\begin{array}{c}\text { POWER } \\
\text { WAS } \\
\text { RESET' } \\
\text { MESSAGE } \\
\text { (ROB, } \\
2 / 11) \\
\end{array}$ & $\begin{array}{c}\text { WORKED OK FOR FEB } 2011 \\
\text { BUCKET TEST }\end{array}$ \\
\hline 1193205 & $\begin{array}{l}\text { GOOD } \\
(<0.01)\end{array}$ & & 0.012 & & -0.065 & $\begin{array}{c}\text { DID NOT } \\
\text { READ } \\
\text { OUT FOR } \\
\text { ROB }(2 / 11) \\
\end{array}$ & $\begin{array}{c}\text { WORKED OK FOR FEB } 2011 \\
\text { BUCKET TEST }\end{array}$ \\
\hline 1193206 & $\begin{array}{l}\text { GOOD } \\
(<0.01)\end{array}$ & & & & & low by 0.01 & river tests August 2010 \\
\hline 1193207 & $\begin{array}{c}\text { high by } \\
0.025\end{array}$ & & -0.015 & & -0.091 & $\begin{array}{c}\text { VERY } \\
\text { HIGH } \\
\text { READINGS } \\
\text { AND THEN } \\
\text { DIED (ROB, } \\
2 / 11) \\
\end{array}$ & $\begin{array}{l}\text { WORKED OK FOR FEB } 2011 \\
\text { BUCKET TEST }\end{array}$ \\
\hline 1193208 & $\begin{array}{l}\text { low by } \\
0.033\end{array}$ & & -0.017 & & & & \\
\hline 1193209 & & & & & -0.042 & & \\
\hline 1193210 & $\begin{array}{l}\text { low by } \\
0.021\end{array}$ & & & & & & \\
\hline 1193211 & $\begin{array}{l}\text { low by } \\
0.026\end{array}$ & & -0.010 & & & & \\
\hline 1193212 & $\begin{array}{l}\text { GOOD } \\
(<0.01) \\
\end{array}$ & & -0.035 & & & & \\
\hline 1193213 & $\begin{array}{c}\text { high by } \\
0.02\end{array}$ & & 0.032 & & & & \\
\hline
\end{tabular}




\begin{tabular}{|c|c|c|c|c|c|c|c|}
\hline 1193214 & $\begin{array}{l}\text { low by } \\
0.003\end{array}$ & river tests August 2010 & & & & & \\
\hline 1193215 & $\begin{array}{c}\text { high by } \\
0.014\end{array}$ & river tests August 2010 & & & & good & R0651002_abv_Ic_camp_h2 \\
\hline 1258706 & & & & & 0.022 & & \\
\hline 1258708 & $\begin{array}{l}\text { high by } \\
0.01\end{array}$ & river tests August 2010 & & & & & \\
\hline 1258708 & $\begin{array}{c}\text { LOW BY } \\
.008 \\
\end{array}$ & $\begin{array}{l}\text { based on bucket test in August } 2010 \\
\text { with } 2 \text { other 'accurate' Hobos (see } \\
\text { HOBO_BUCKET_TEST_AUG10.XLS }\end{array}$ & & & & & \\
\hline 1258709 & $\begin{array}{c}\text { HIGH BY } \\
0.129 \\
\end{array}$ & & 0.086 & & & & \\
\hline 1258710 & $\begin{array}{c}\text { high by } \\
0.092\end{array}$ & & 0.090 & & & & \\
\hline 1258715 & $\begin{array}{l}\text { high by } \\
0.051\end{array}$ & & 0.045 & & & & \\
\hline 1258718 & $\begin{array}{l}\text { low by } \\
0.014\end{array}$ & $\begin{array}{c}\text { river tests August } 2010 \text { (165 Mile } \\
\text { test) }\end{array}$ & & & & & \\
\hline 1258721 & $\begin{array}{l}\text { GOOD } \\
(<0.01)\end{array}$ & & 0.017 & 0.041 & & & \\
\hline 1258724 & $\begin{array}{l}\text { high by } \\
0.044\end{array}$ & & 0.065 & & & & \\
\hline 1258725 & & & & & 0.083 & & \\
\hline 1258727 & $\begin{array}{l}\text { high by } \\
0.071\end{array}$ & & 0.065 & & & & \\
\hline 1258729 & $\begin{array}{c}\text { high by } \\
0.078\end{array}$ & & & & & & \\
\hline 1258730 & $\begin{array}{l}\text { high by } \\
0.095\end{array}$ & & 0.087 & & & & \\
\hline 1258732 & $\begin{array}{l}\text { low by } \\
0.07\end{array}$ & river tests August 2010 & & & & & \\
\hline 1258736 & $\begin{array}{c}\text { HIGH BY } \\
0.123 \\
\end{array}$ & & 0.078 & & 0.137 & & \\
\hline 1258738 & & & & & 0.003 & & \\
\hline 1258742 & & & & & -0.043 & & \\
\hline 1258744 & $\begin{array}{l}\text { GOOD } \\
(<0.01) \\
\end{array}$ & & -0.035 & -0.015 & & & \\
\hline 1258746 & & & & & 0.043 & & \\
\hline 1258747 & & & 0.094 & & 0.088 & & \\
\hline 1258748 & & & & & -0.051 & & \\
\hline 1258749 & & & & & 0.061 & & \\
\hline 1258760 & $\begin{array}{l}\text { high by } \\
0.052\end{array}$ & river tests August 2010 & & & & good & $\mathrm{HA} 100217 \mathrm{H} 4$ \\
\hline 1258761 & & & & & 0.052 & & \\
\hline
\end{tabular}




\begin{tabular}{|c|c|c|c|c|c|c|c|}
\hline 1258762 & $\begin{array}{l}\text { high by } \\
0.089\end{array}$ & river tests August 2010 & & & & good & R0631002_across_from_hi_h2 \\
\hline 1258763 & & & & & 0.039 & & \\
\hline 1258770 & $\begin{array}{l}\text { high by } \\
0.048\end{array}$ & river tests August 2010 & & & 0.010 & & \\
\hline 1258771 & & & & & 0.105 & $\begin{array}{c}\text { SKIPPED } \\
\sim 40 \\
\text { MINUTE } \\
\text { READINGS } \\
\text { IN FEB } \\
2011 \\
\text { BUCKET } \\
\text { TEST } \\
\text { PROBABLY } \\
\text { DO NOT } \\
\text { TRUST } \\
\end{array}$ & \\
\hline 1258772 & $\begin{array}{l}\text { high by } \\
0.113\end{array}$ & river tests August 2010 & & & & & \\
\hline 1258773 & $\begin{array}{l}\text { high by } \\
0.100\end{array}$ & river tests August 2010 & & & & good & LU0217H2 \\
\hline 1258774 & $\begin{array}{l}\text { high by } \\
0.1\end{array}$ & $\begin{array}{c}\text { river tests August } 2010 \text { (165 Mile } \\
\text { test) }\end{array}$ & 0.095 & & & & \\
\hline 1258777 & $\begin{array}{l}\text { high by } \\
0.038\end{array}$ & river tests August 2010 & & & & & \\
\hline 1258778 & & & & & -0.026 & & \\
\hline 1258779 & $\begin{array}{l}\text { high by } \\
0.1 \text { to } 0.2 \\
\end{array}$ & river tests August 2010 & 0.093 & & & $\begin{array}{l}\text { high by } \\
\sim 0.1 \\
\end{array}$ & R0651002_abv_lc_camp_h \\
\hline 2342428 & $\begin{array}{l}\text { low by } \\
0.029\end{array}$ & & -0.004 & & & & \\
\hline 2424205 & $\begin{array}{l}\text { low by } \\
0.072\end{array}$ & & & & & & \\
\hline 2424206 & $\begin{array}{l}\text { low by } \\
0.058\end{array}$ & & -0.032 & & & & \\
\hline 2424207 & $\begin{array}{l}\text { low by } \\
0.034\end{array}$ & & & & & $\begin{array}{l}\text { low by } \\
0.024\end{array}$ & river tests August 2010 \\
\hline 2424208 & $\begin{array}{l}\text { GOOD } \\
(<0.01)\end{array}$ & & -0.019 & -0.026 & & & \\
\hline 2424209 & $\begin{array}{l}\text { low by } \\
0.076\end{array}$ & & -0.075 & & & & \\
\hline 2424210 & $\begin{array}{l}\text { low by } \\
0.02\end{array}$ & & -0.034 & -0.013 & & & \\
\hline 2424211 & $\begin{array}{l}\text { low by } \\
0.06\end{array}$ & & -0.055 & & & & \\
\hline 2424212 & $\begin{array}{l}\text { low by } \\
0.011\end{array}$ & & & & & $\begin{array}{l}\text { low by } \\
0.003\end{array}$ & river tests August 2010 \\
\hline 2424213 & $\begin{array}{l}\text { low by } \\
0.053\end{array}$ & & -0.070 & & -0.022 & & \\
\hline 2424214 & $\begin{array}{l}\text { low by } \\
0.015\end{array}$ & & 0.010 & 0.021 & & & \\
\hline 9790775 & & & 0.024 & & & & \\
\hline 9790776 & & & -0.029 & & & & \\
\hline 9790777 & & & -0.082 & & -0.134 & & \\
\hline
\end{tabular}




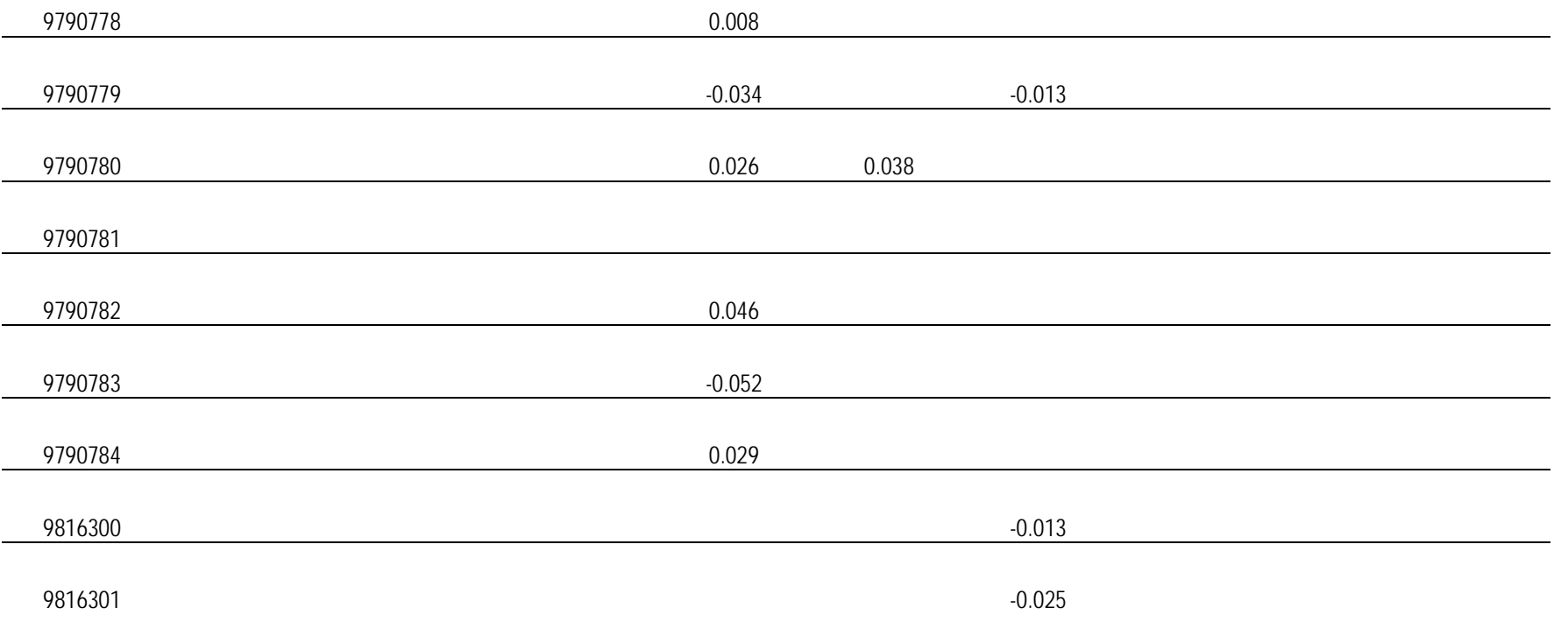




\section{Appendix B. Raw Temperature Data from All Thermistors}

Spreadsheet available for download at http://pubs.usgs.gov/of/2013/1013/ 


\section{Appendix C. Filtered Temperature Data for All Study Sites}


Filtered temperature at 15 minute intervals, 63.65R, July 2010

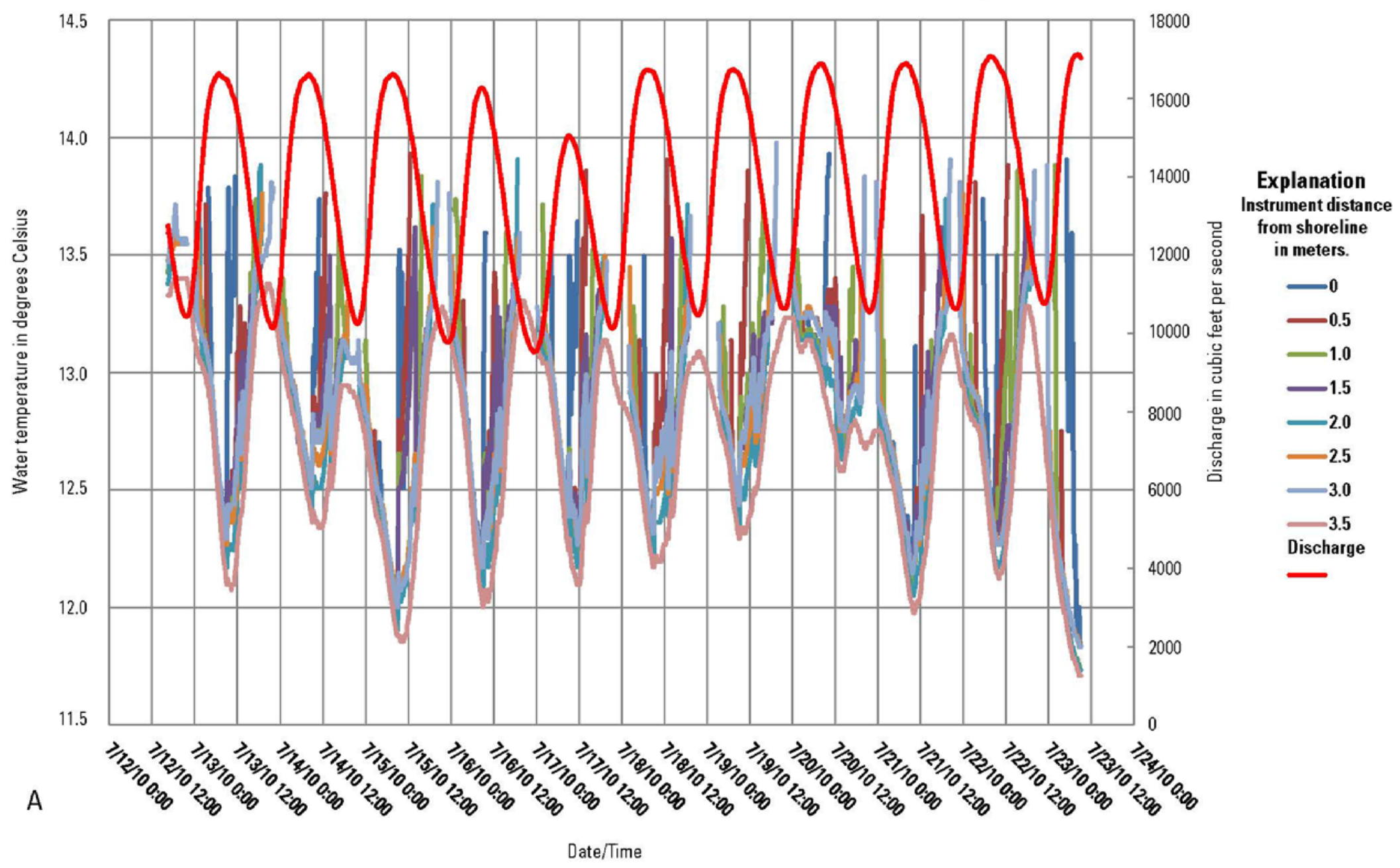


Filtered temperature at $\mathbf{1 5}$ minute intervals, 63.81R, July 2010

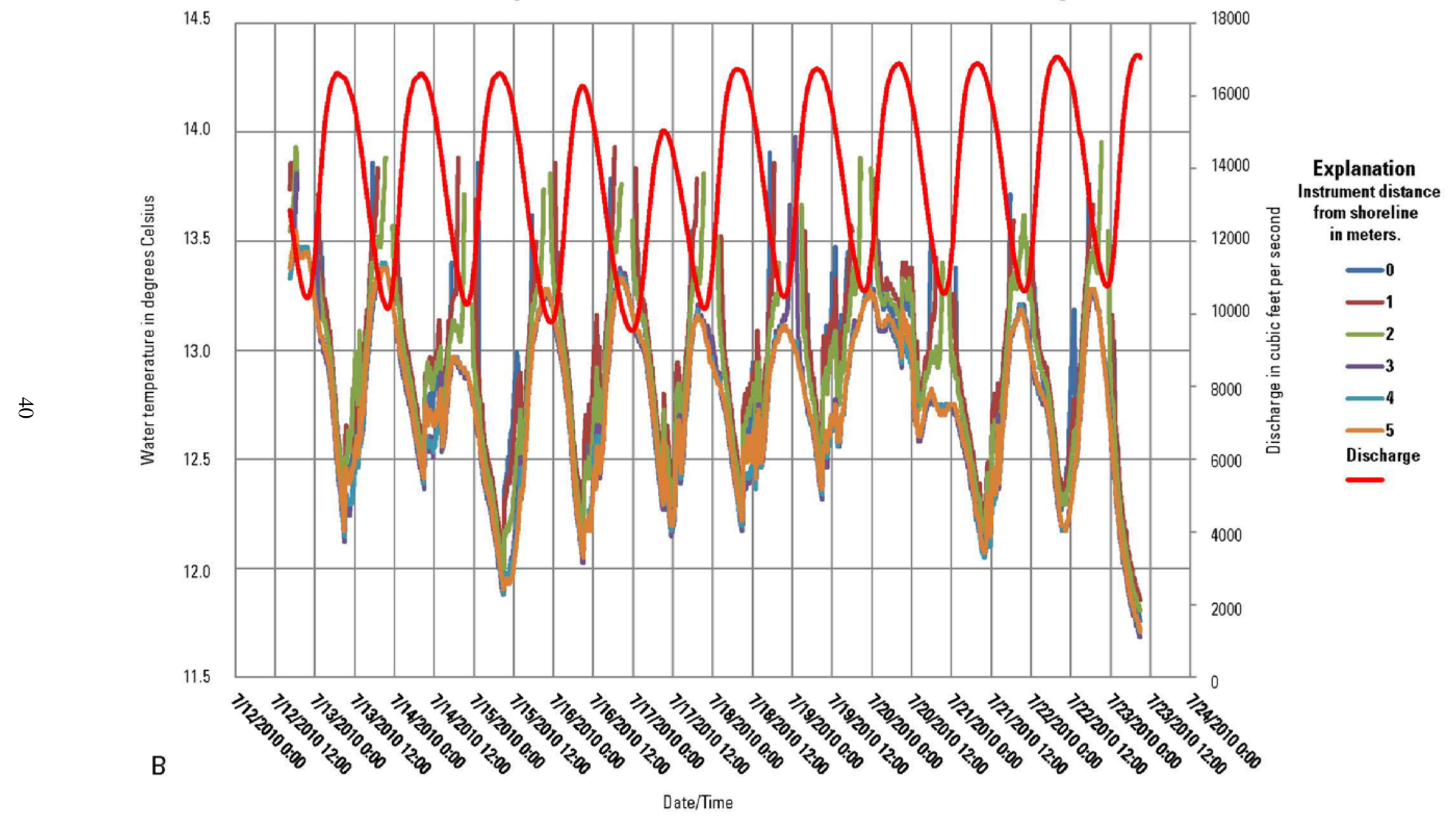


Filtered temperature at 15 minute intervals, 64.29R, July 2010

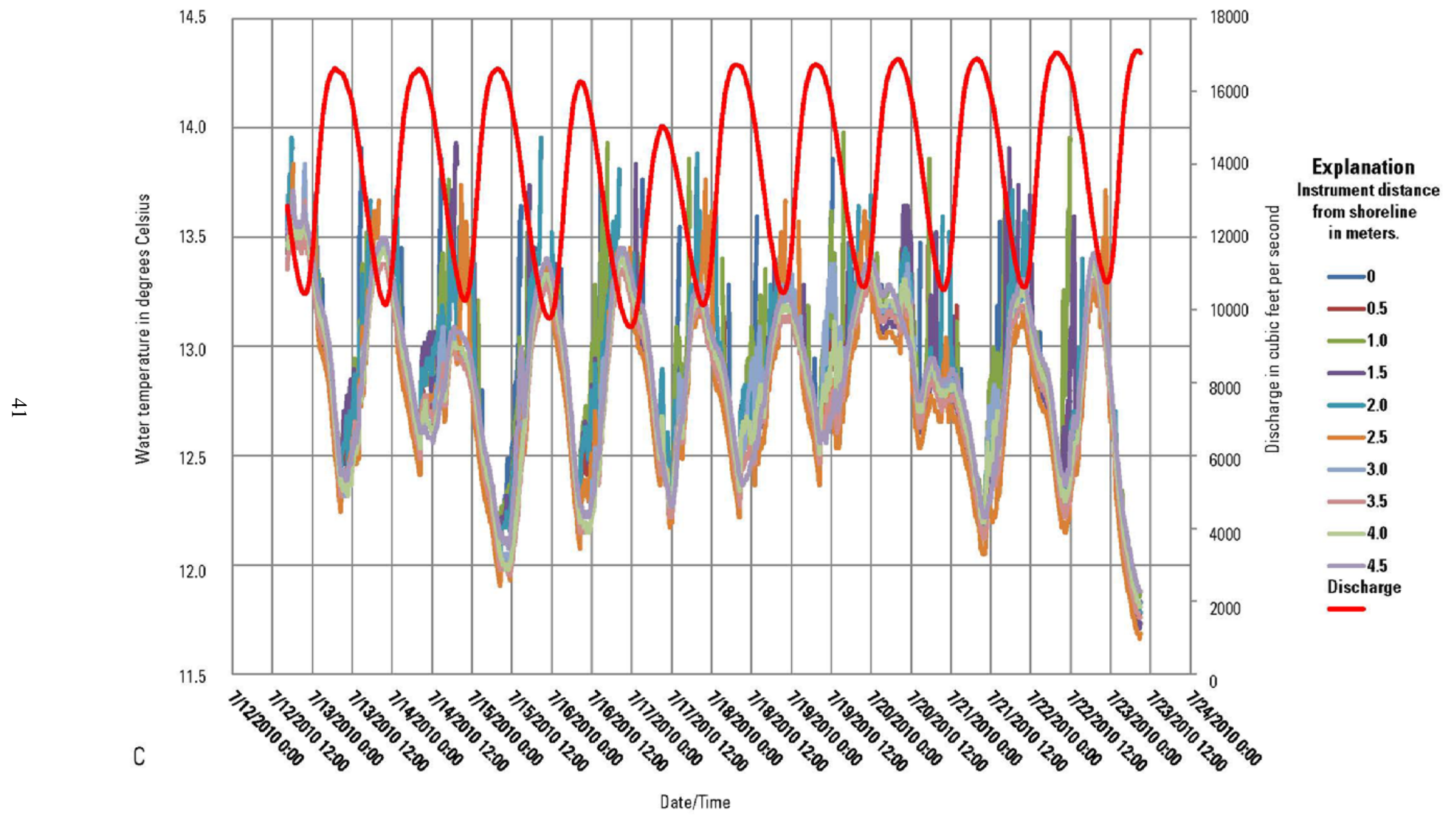


Filtered temperature at 15 minute intervals, 65.10L, July 2010

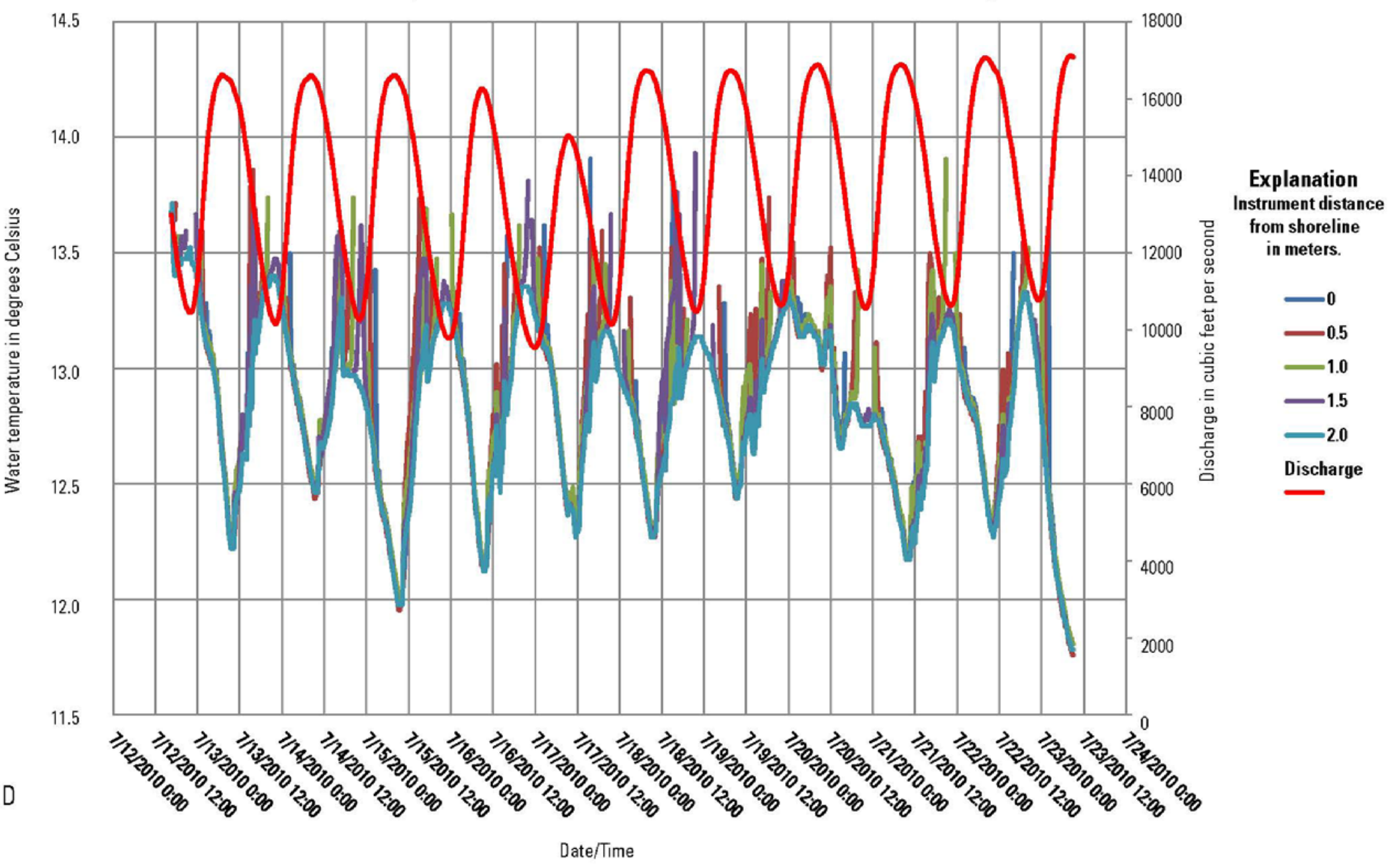


Filtered temperature at 15 minute intervals, 65.78L, July 2010

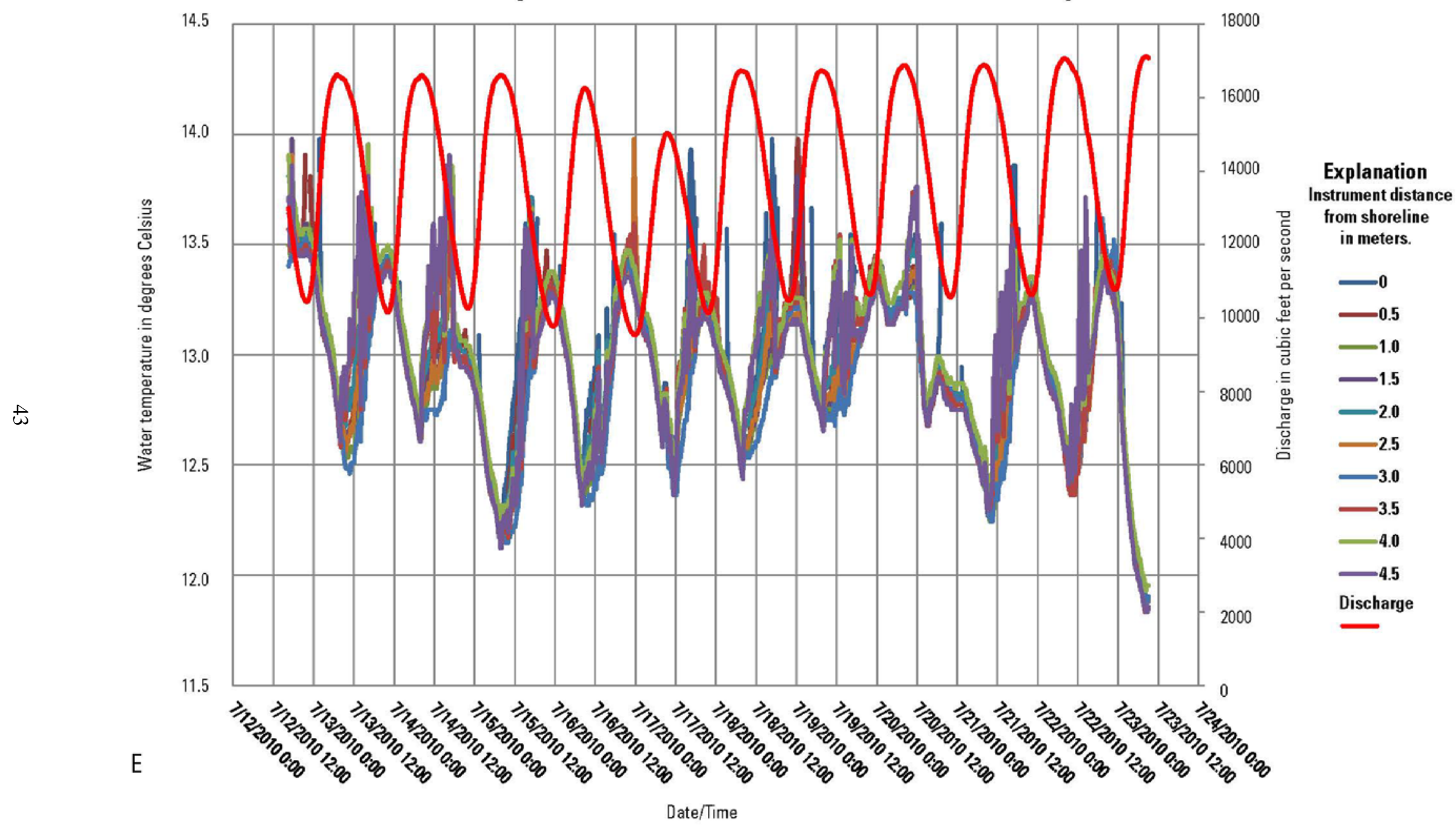


Filtered temperature at 15 minute intervals, 63.33R, August 2010

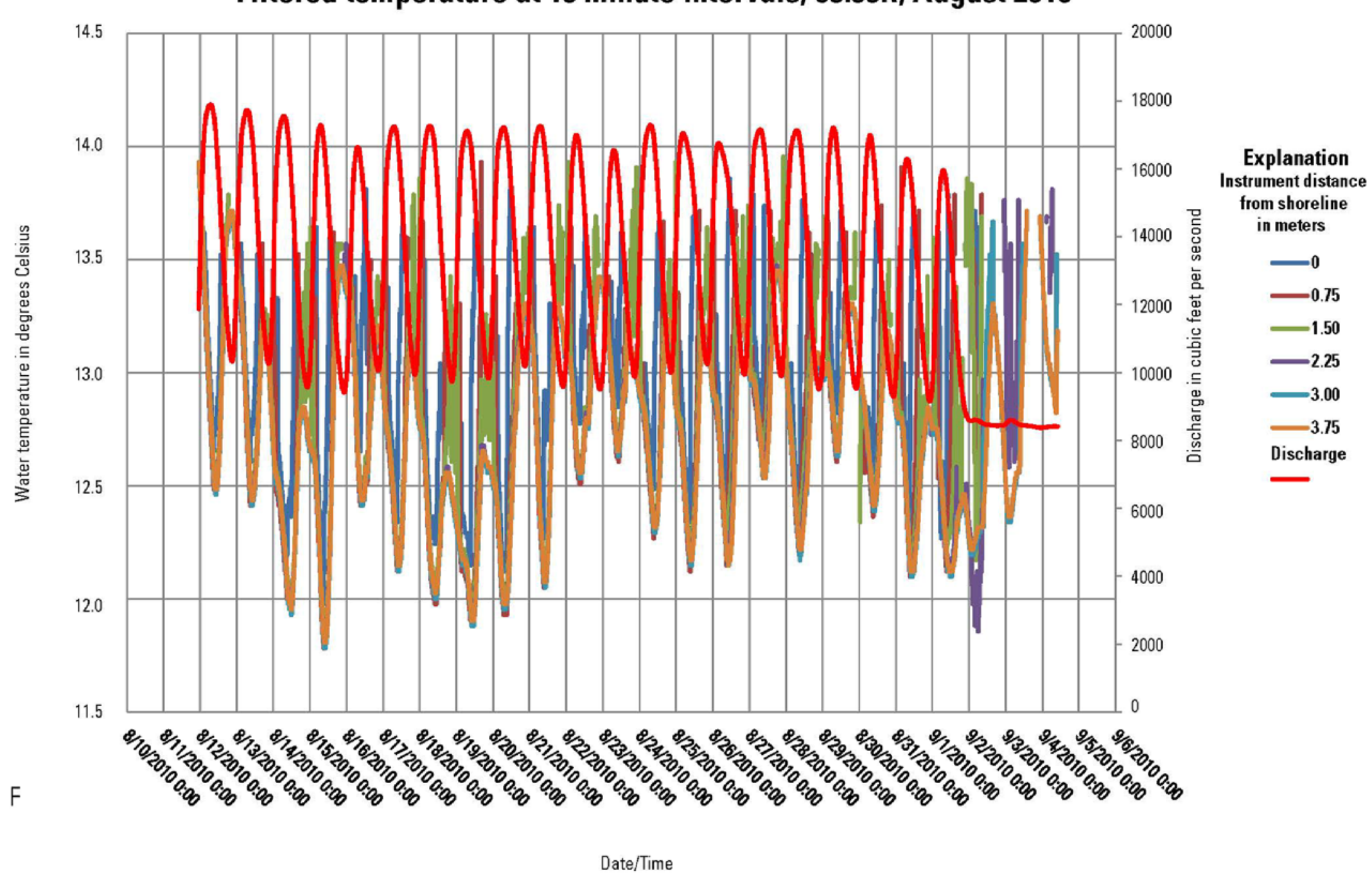


Filtered temperature at 15 minute intervals, 63.56R, August 2010

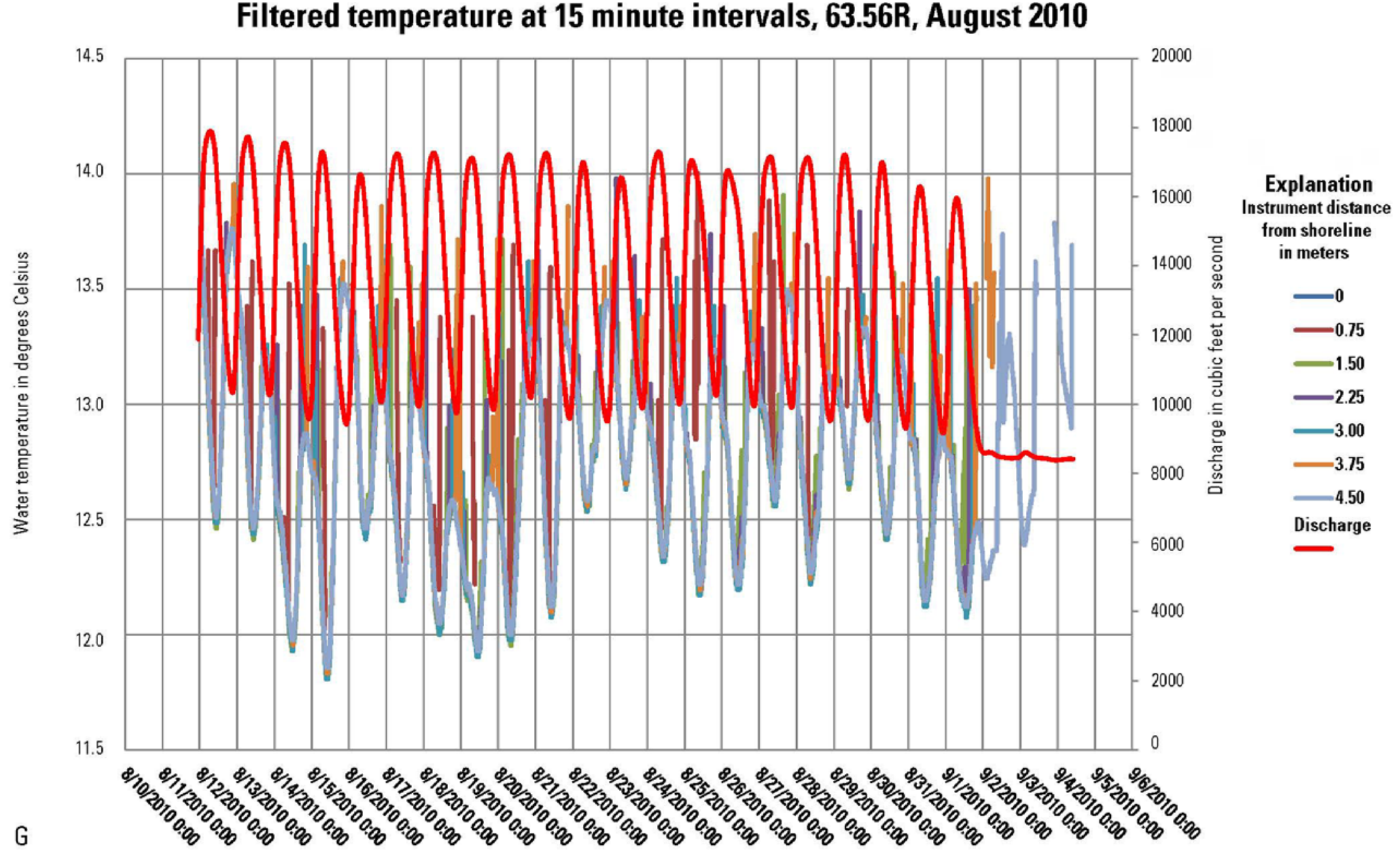


Filtered temperature at 15 minute intervals, 63.81R, August 2010

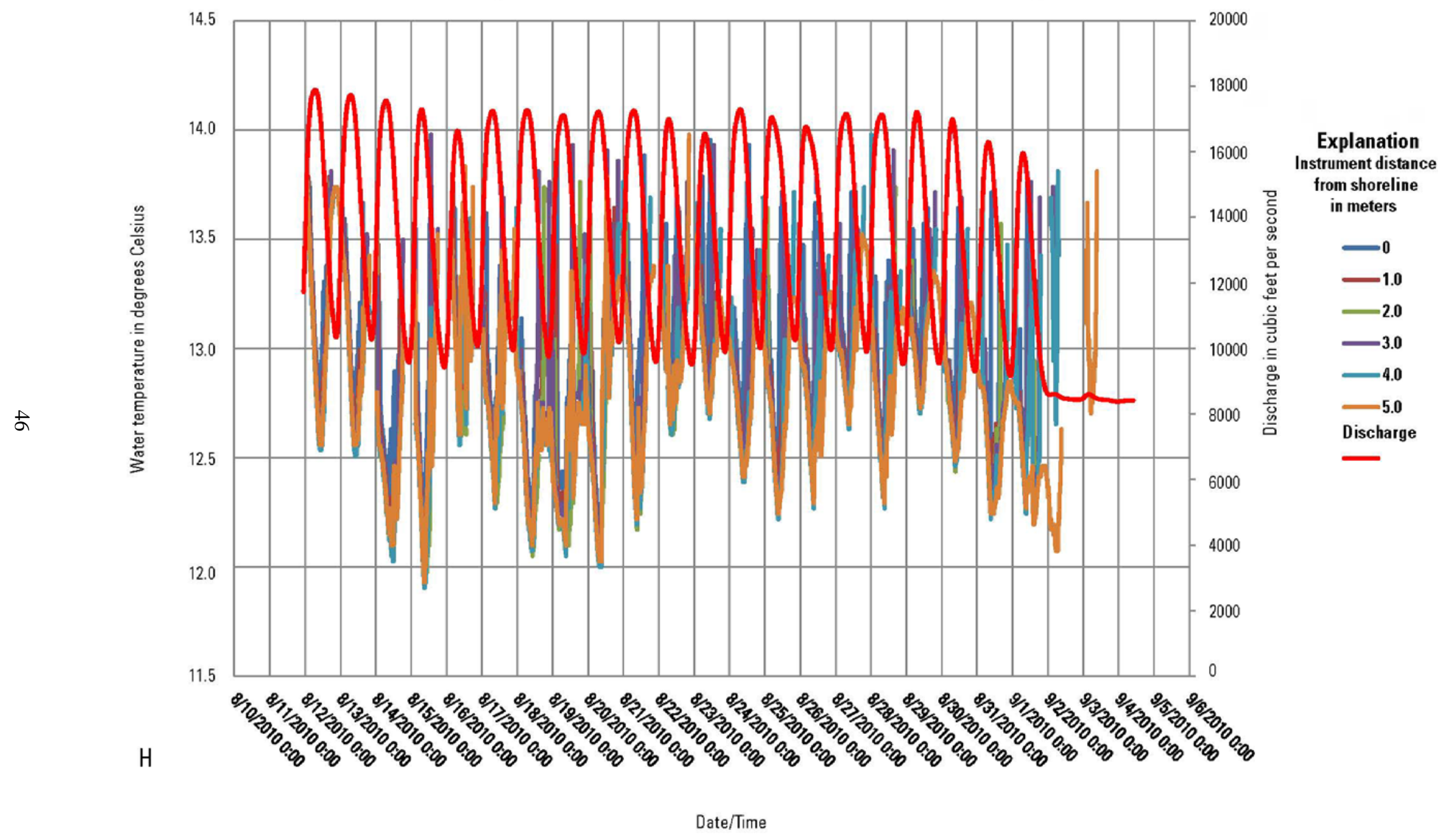


Filtered temperature at $\mathbf{1 5}$ minute intervals, 64.29R, August 2010

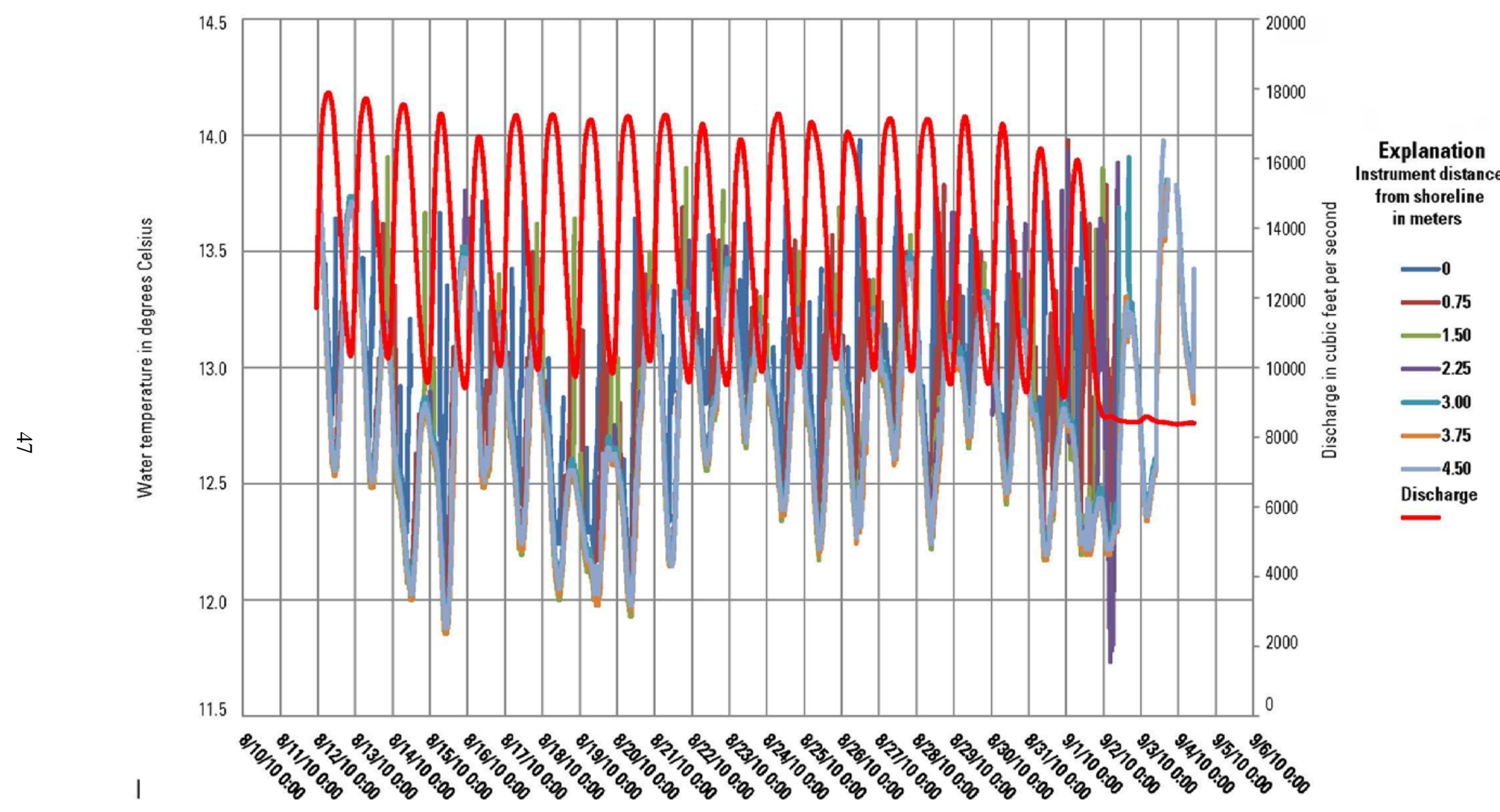




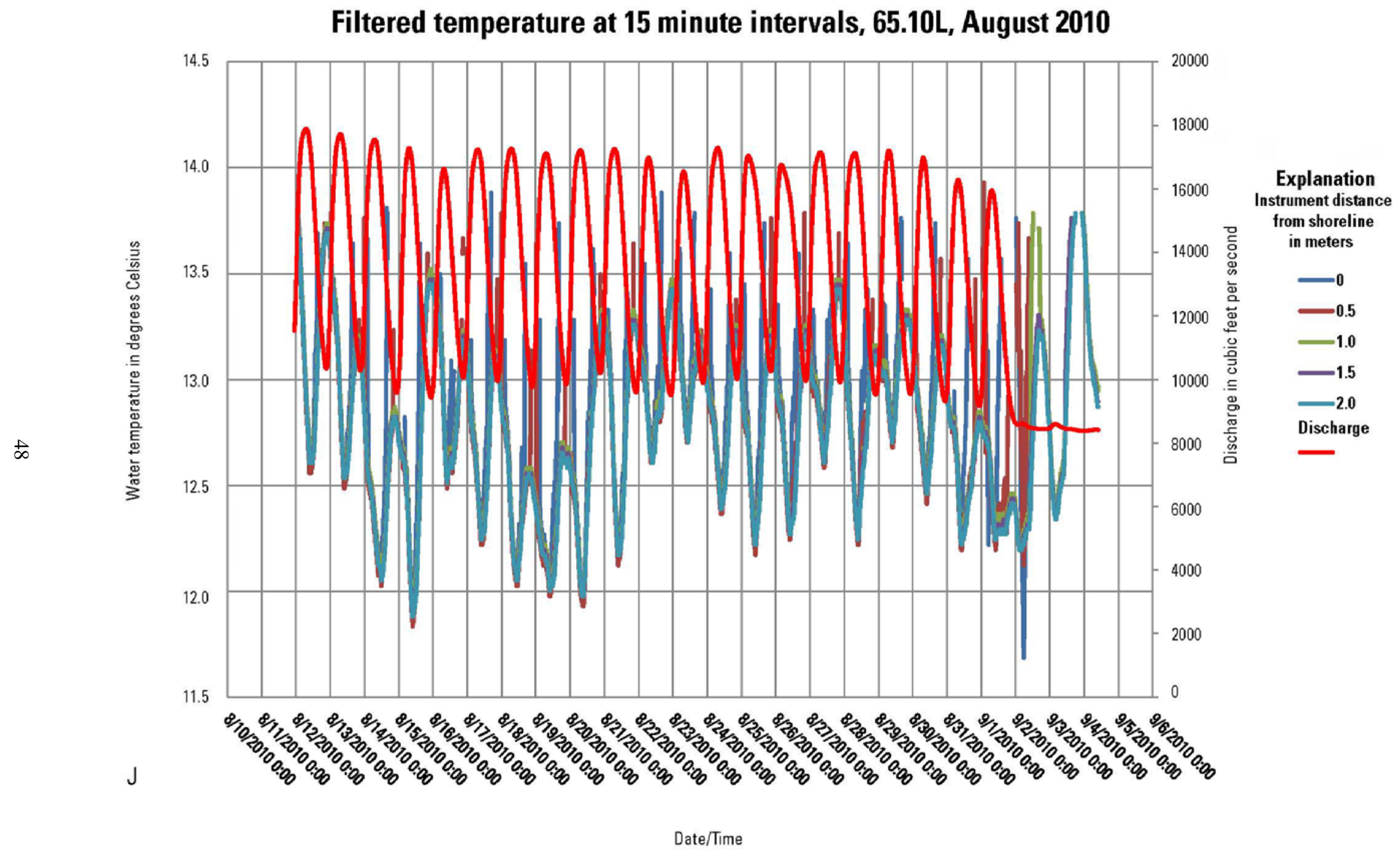




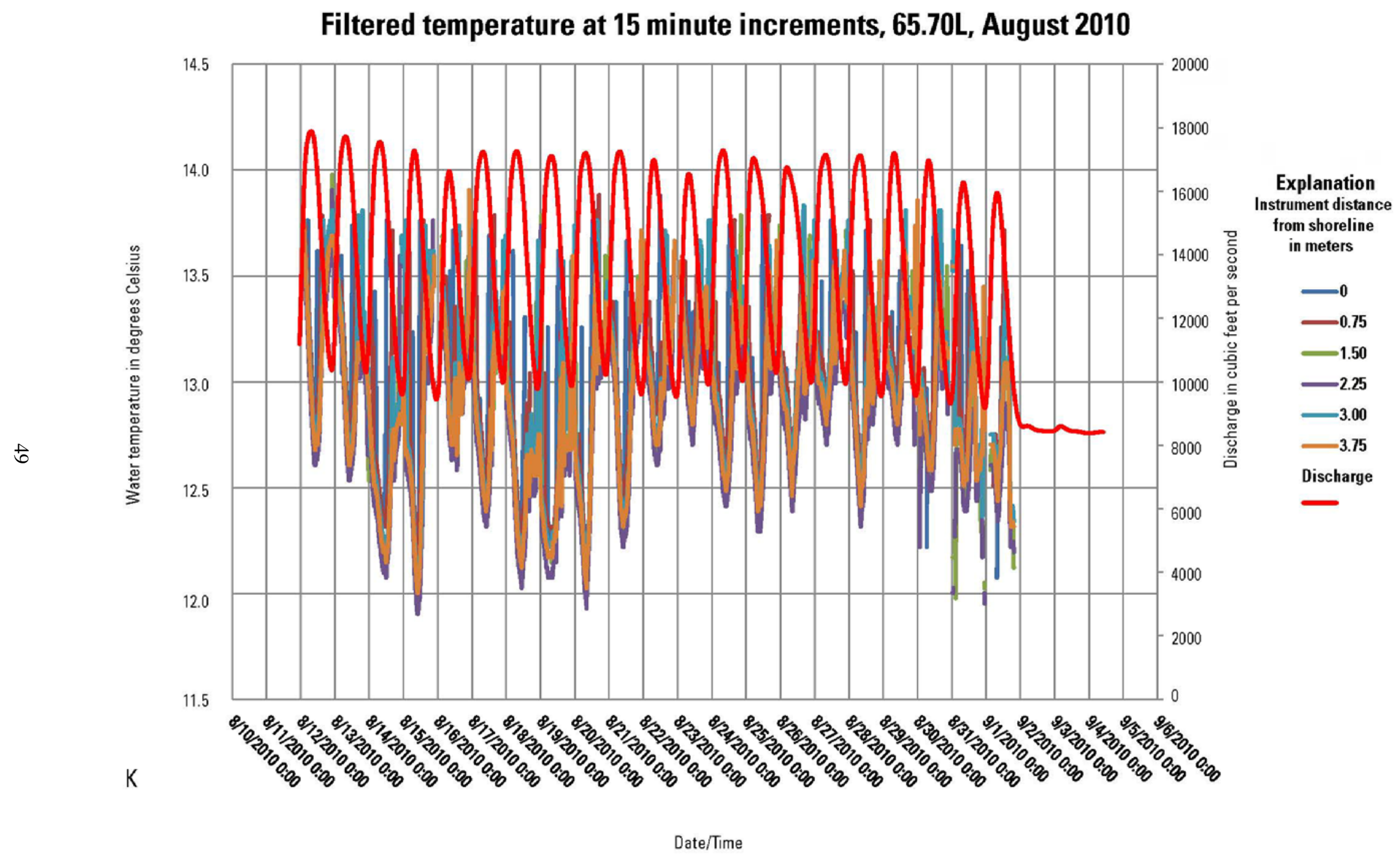


Filtered temperature at 15 minute intervals, 65.78L, August 2010

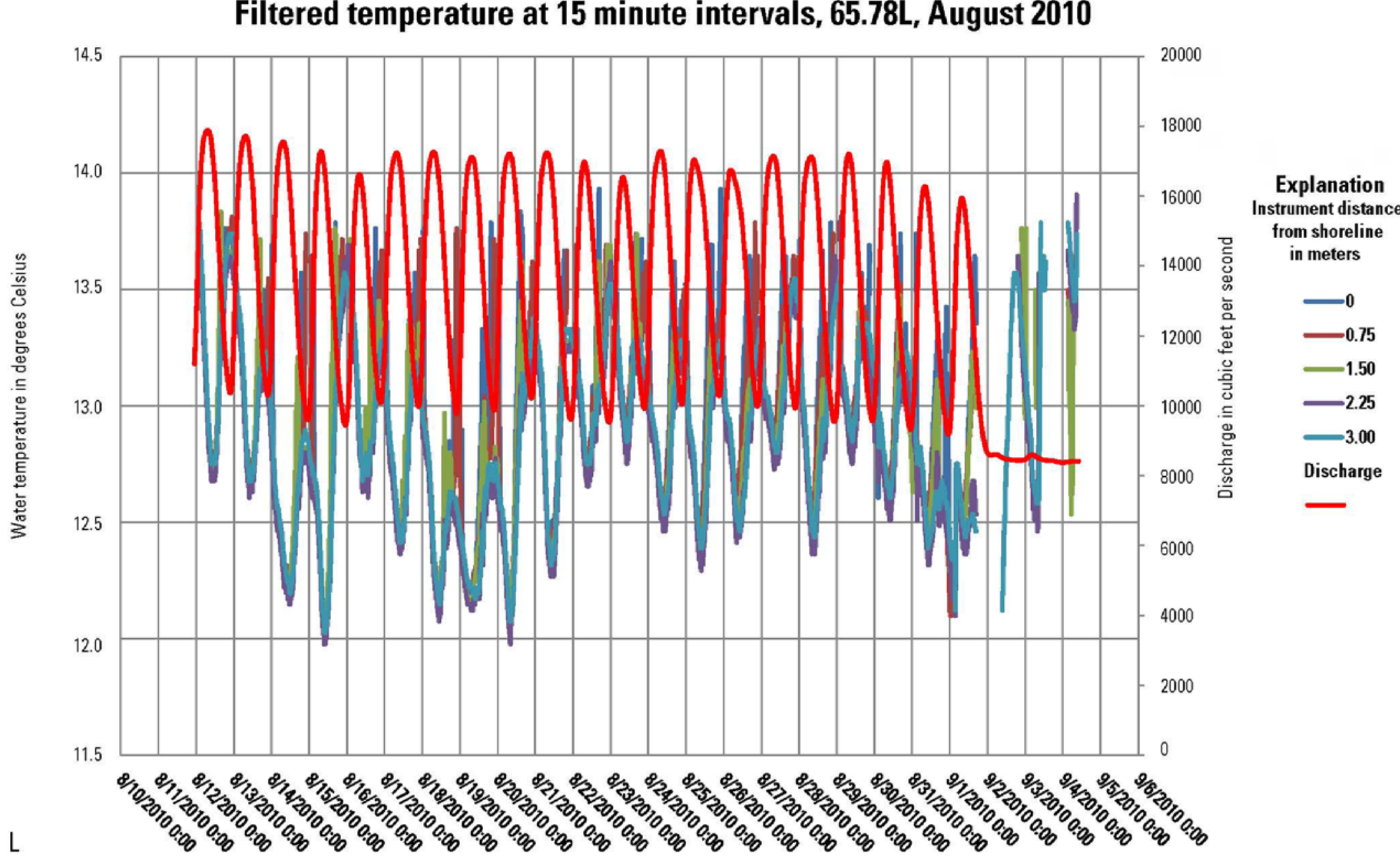


Filtered temperature at $\mathbf{1 5}$ minute intervals, 63.33R, September 2010

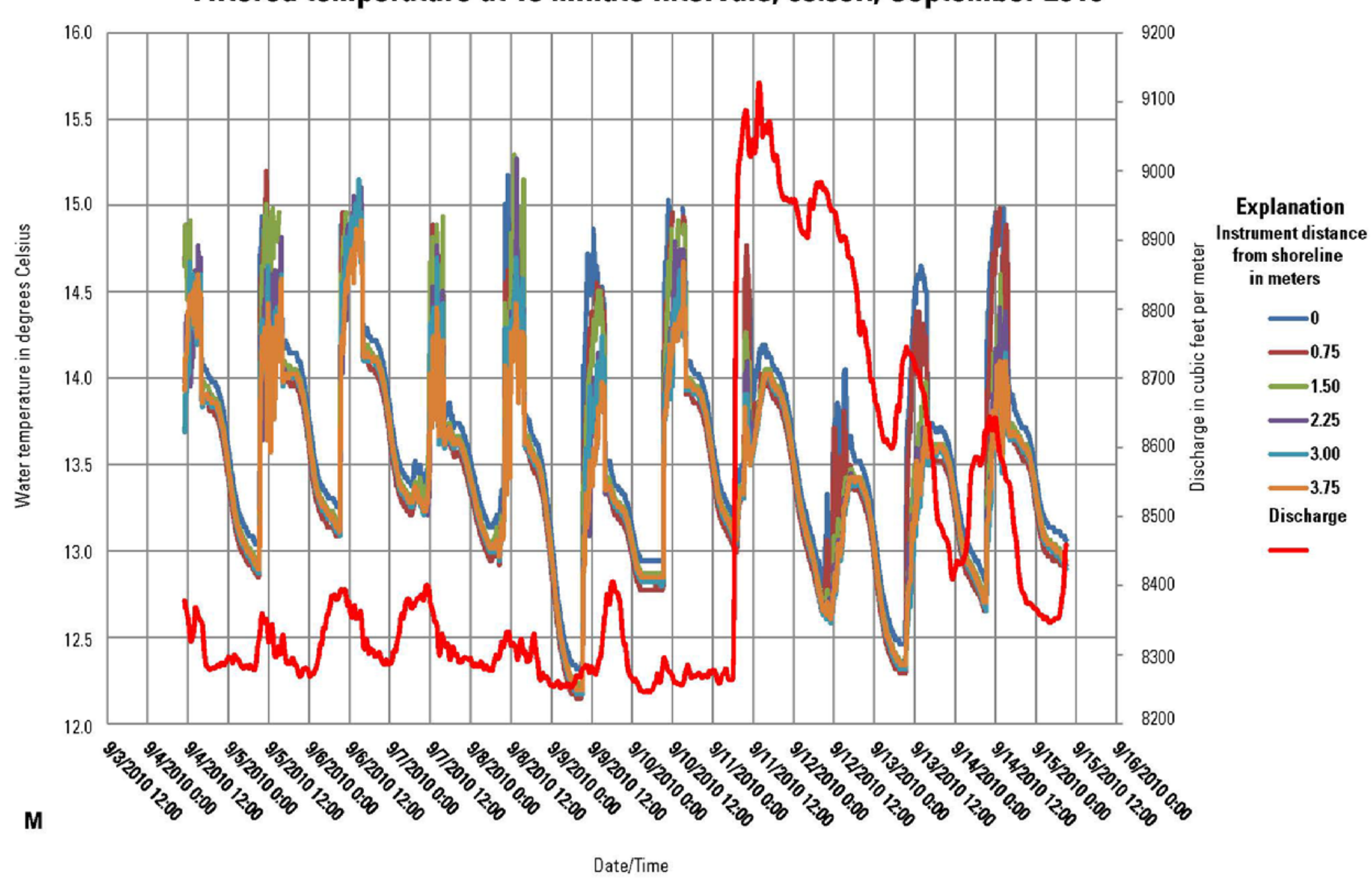


Filtered temperature at 15 minute intervals, 63.56R, September 2010

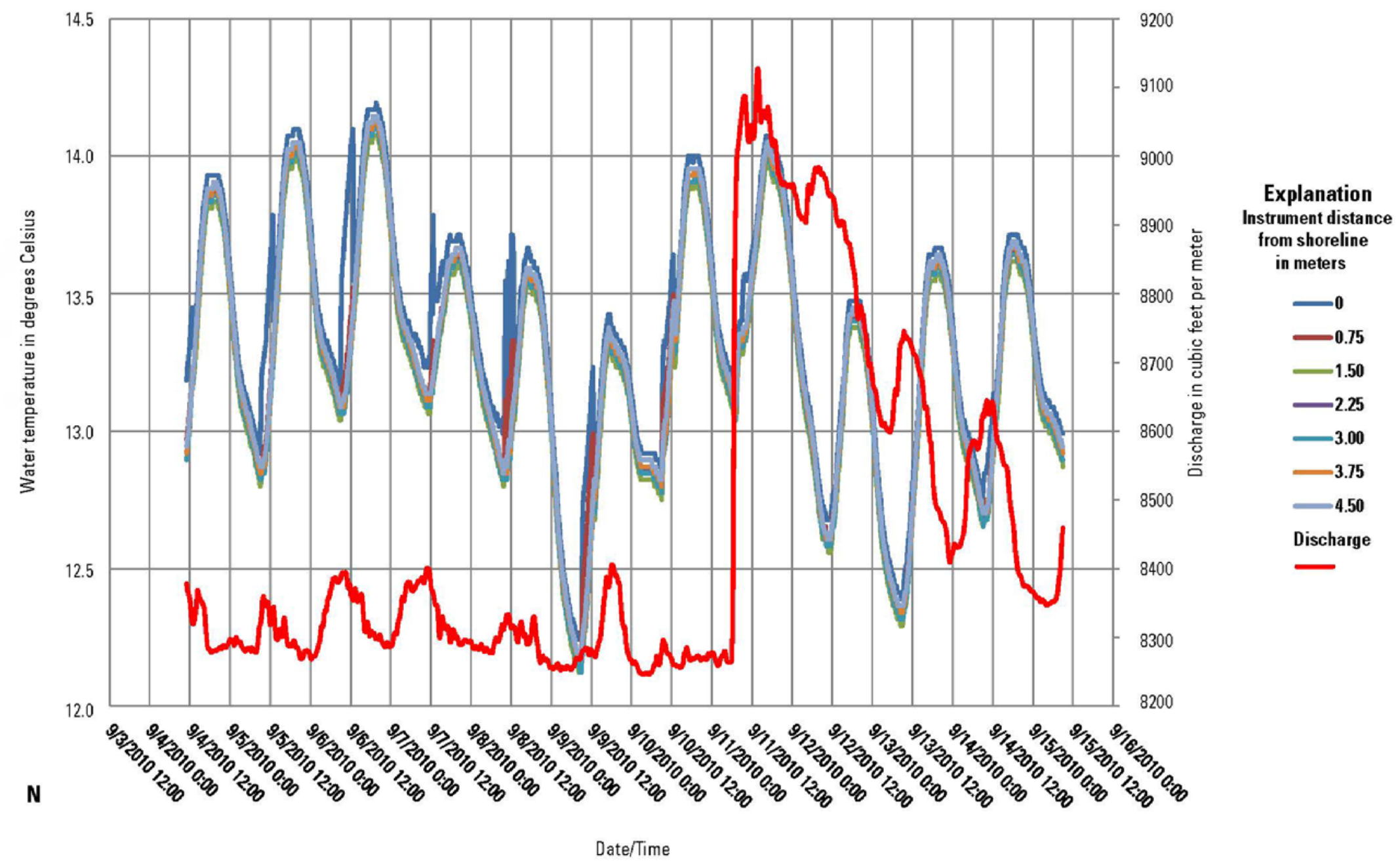


Filtered temperature at $\mathbf{1 5}$ minute intervals, 63.81R, September 2010

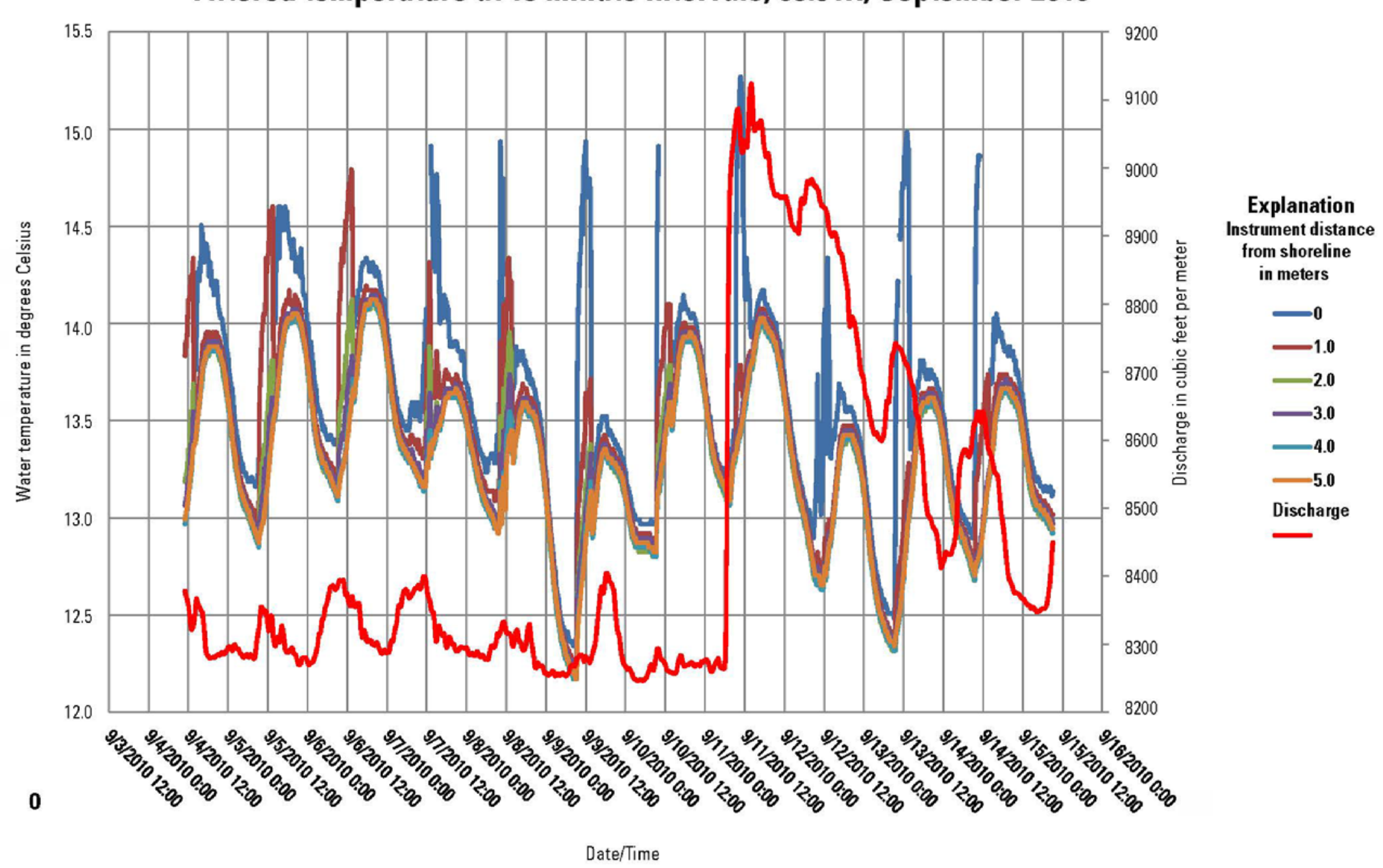


Filtered temperature at 15 minute intervals, 64.29R, September 2010

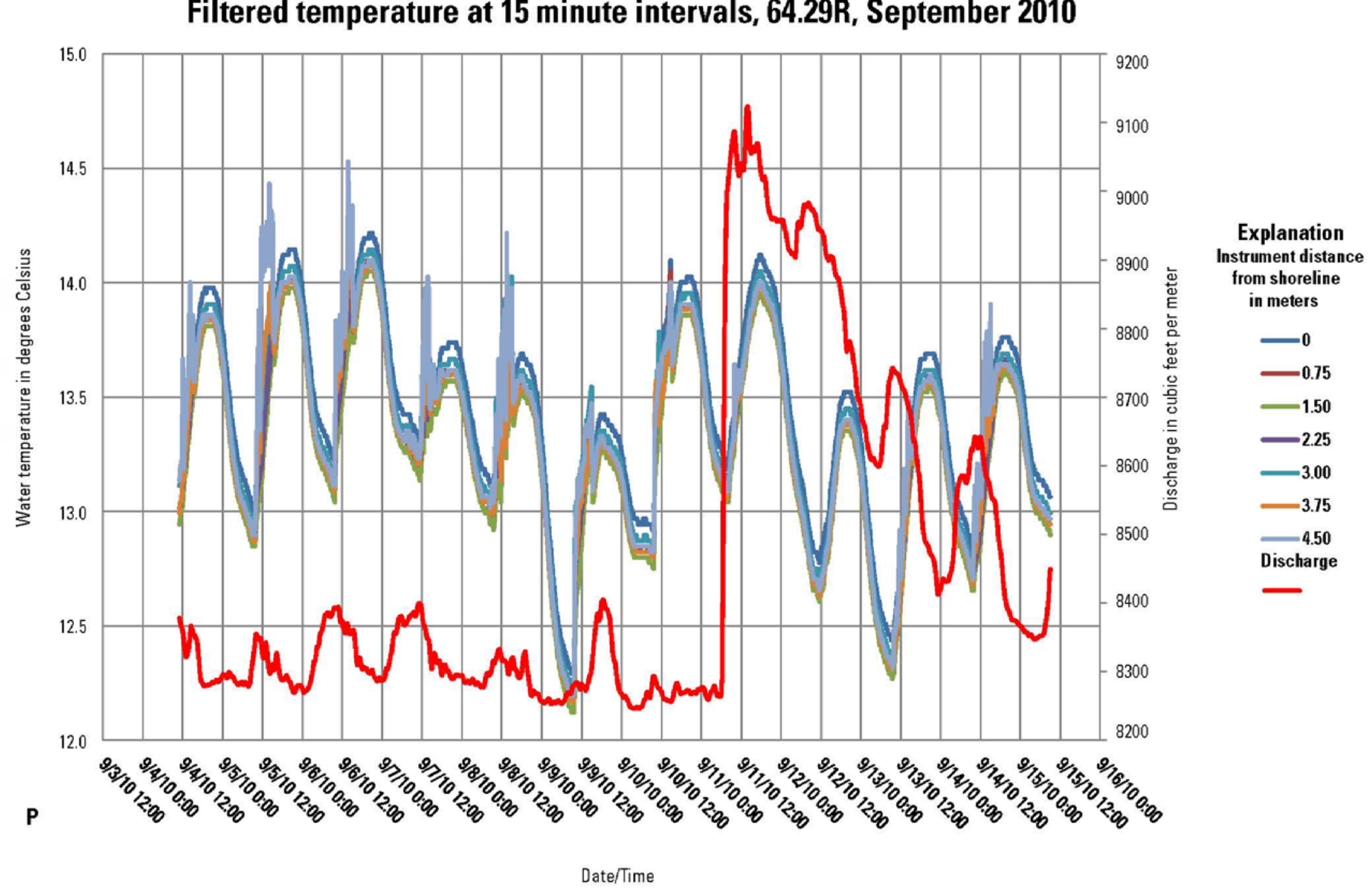


Filtered temperature at 15 minute increments, 65.10L, September 2010

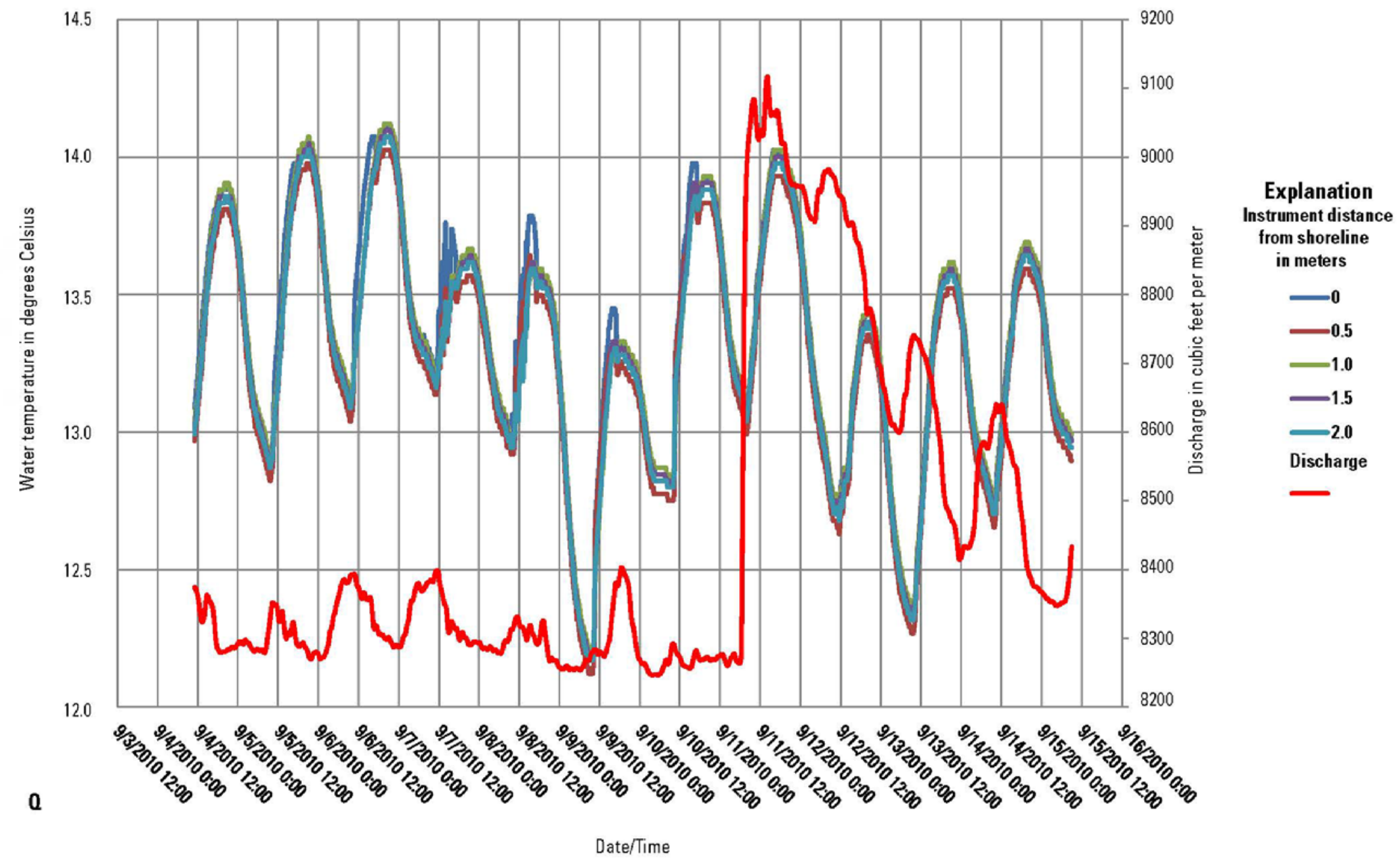


Filtered temperature at 15 minute intervals, 65.70L, September 2010

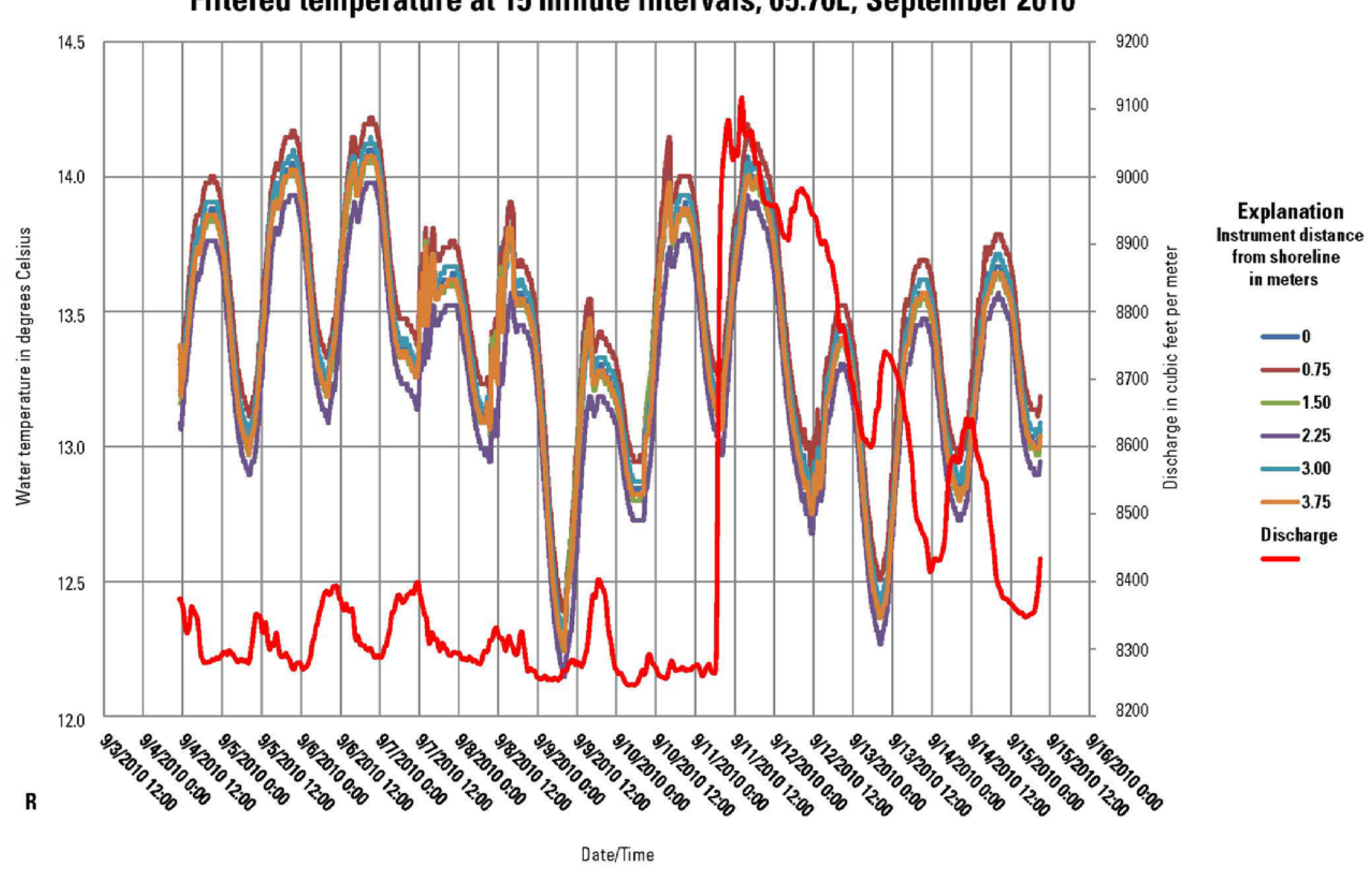


Filtered temperature at 15 minute increments, 65.78L, September 2010

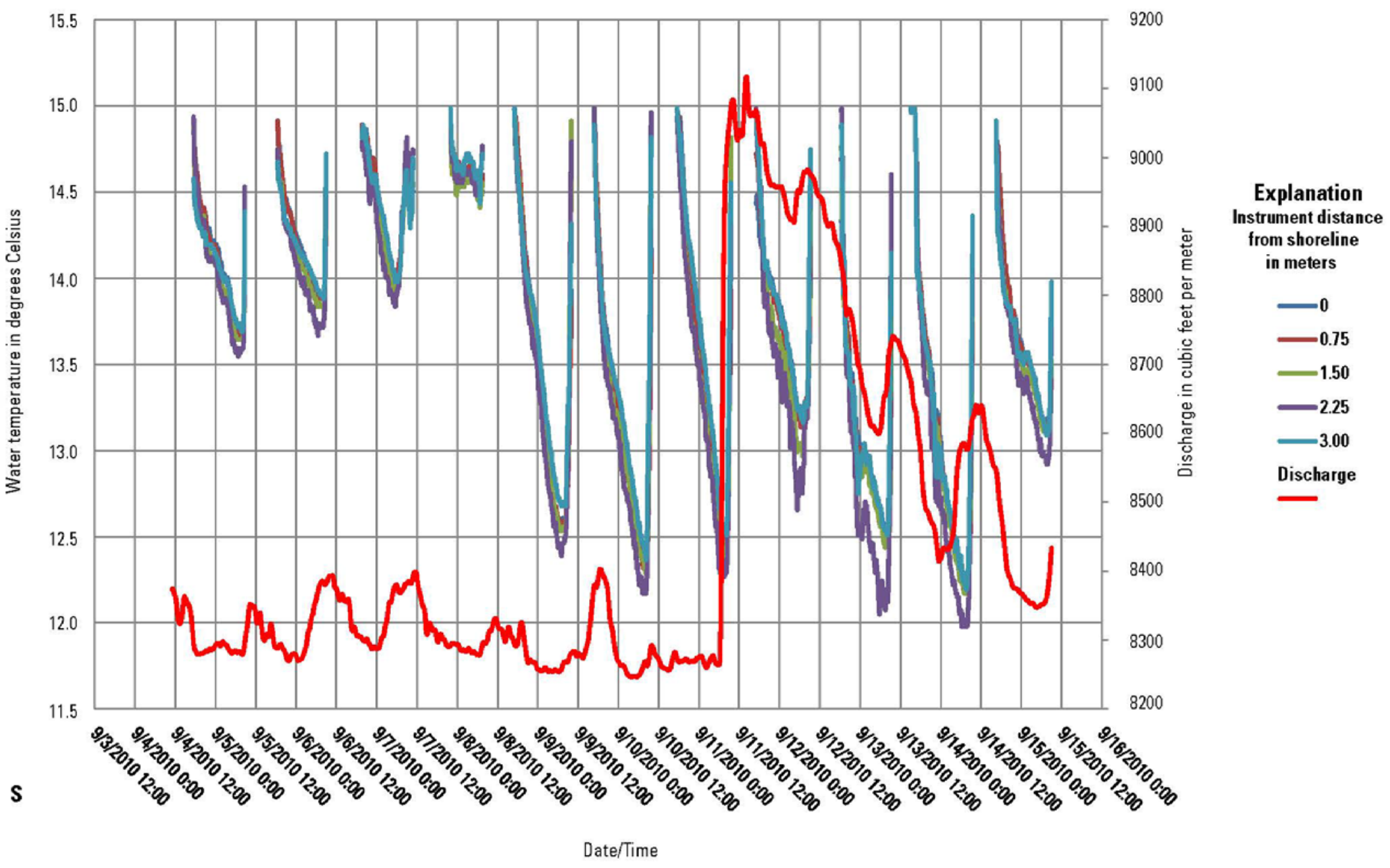


Filtered temperature at $\mathbf{1 5}$ minute intervals, 63.33R, 0ctober 2010

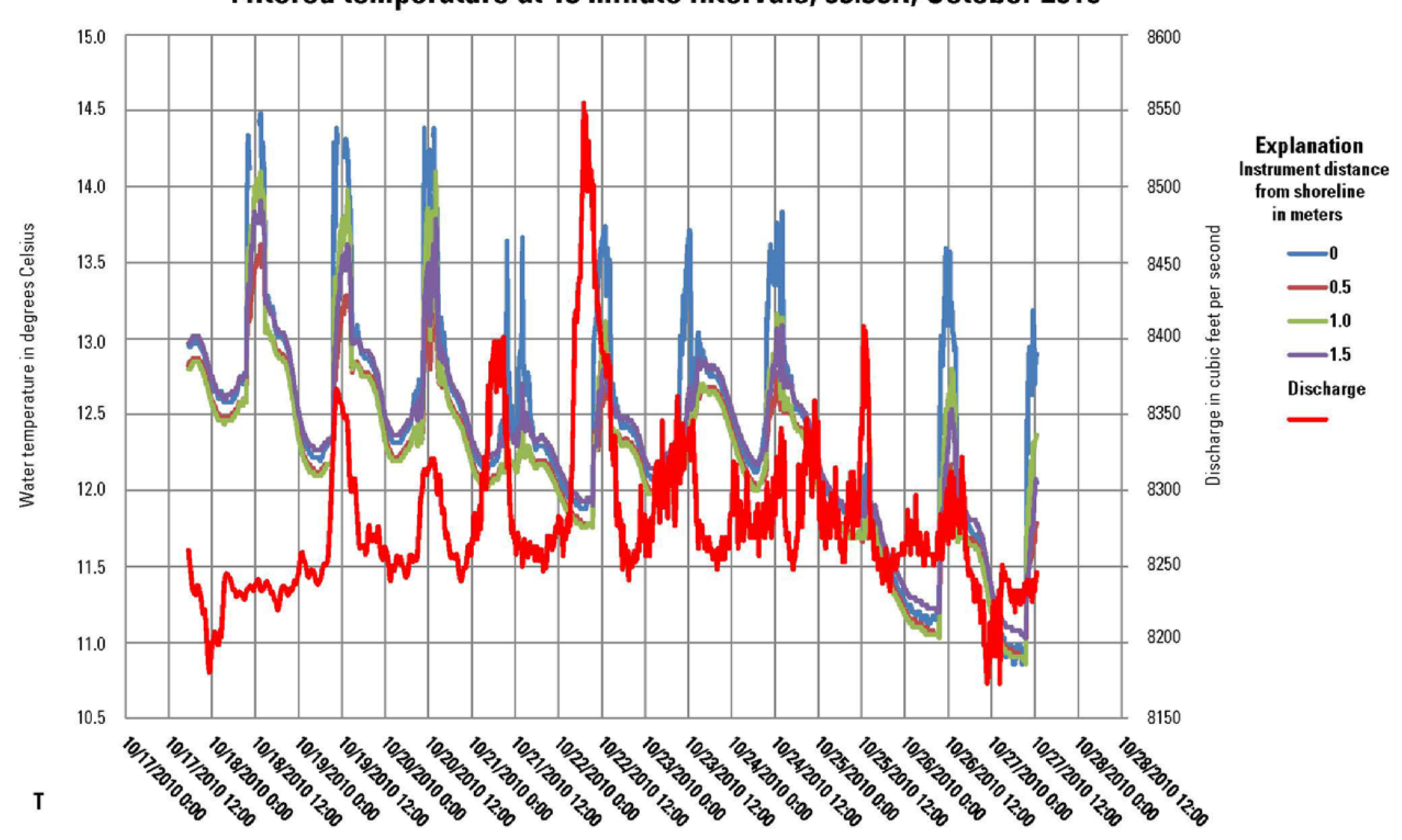


Filtered temperature data at 15 minute intervals, 63.56R, 0ctober 2010

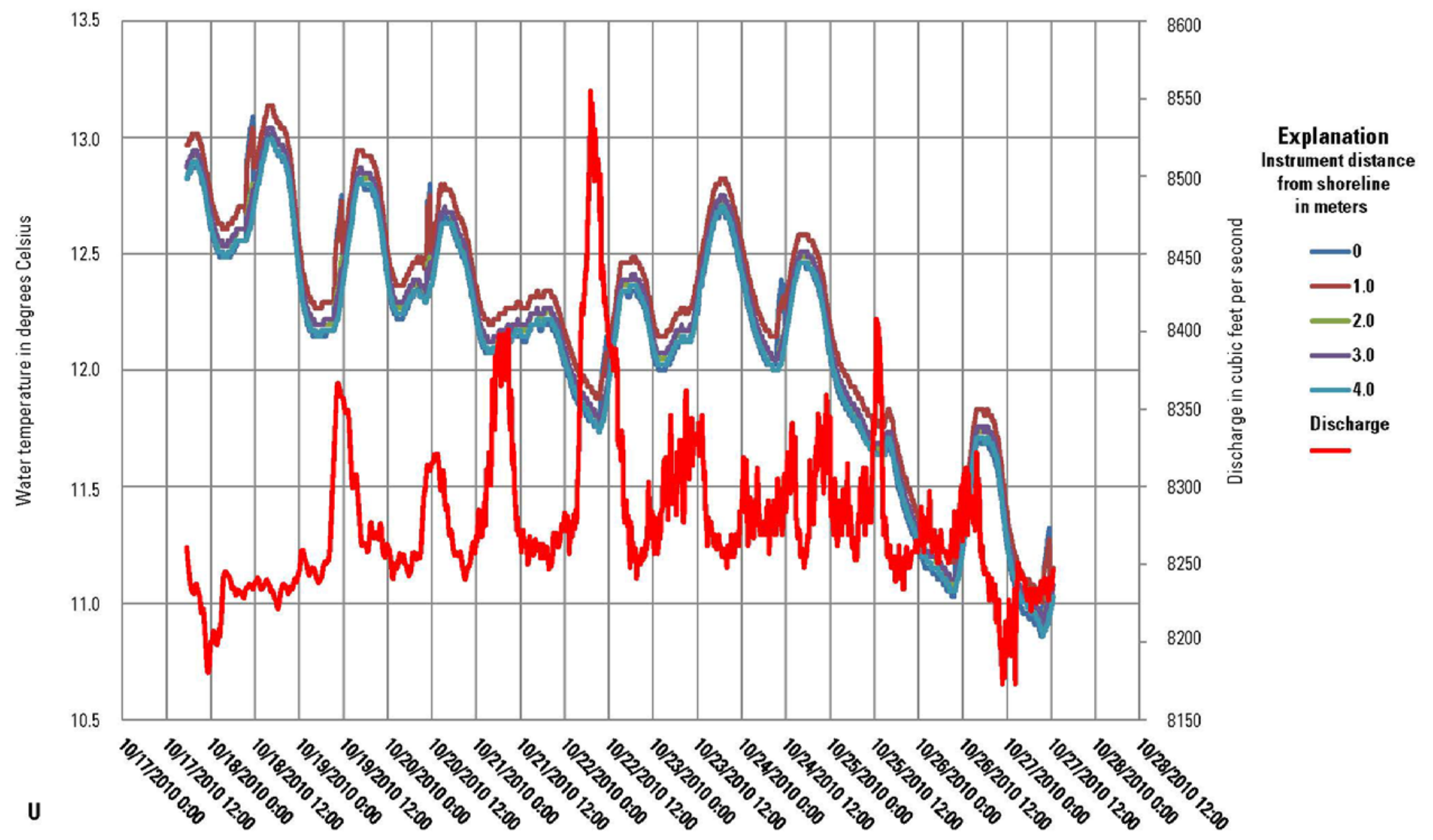


Filtered temperature at 15 minute intervals, 63.81R, 0ctober 2010

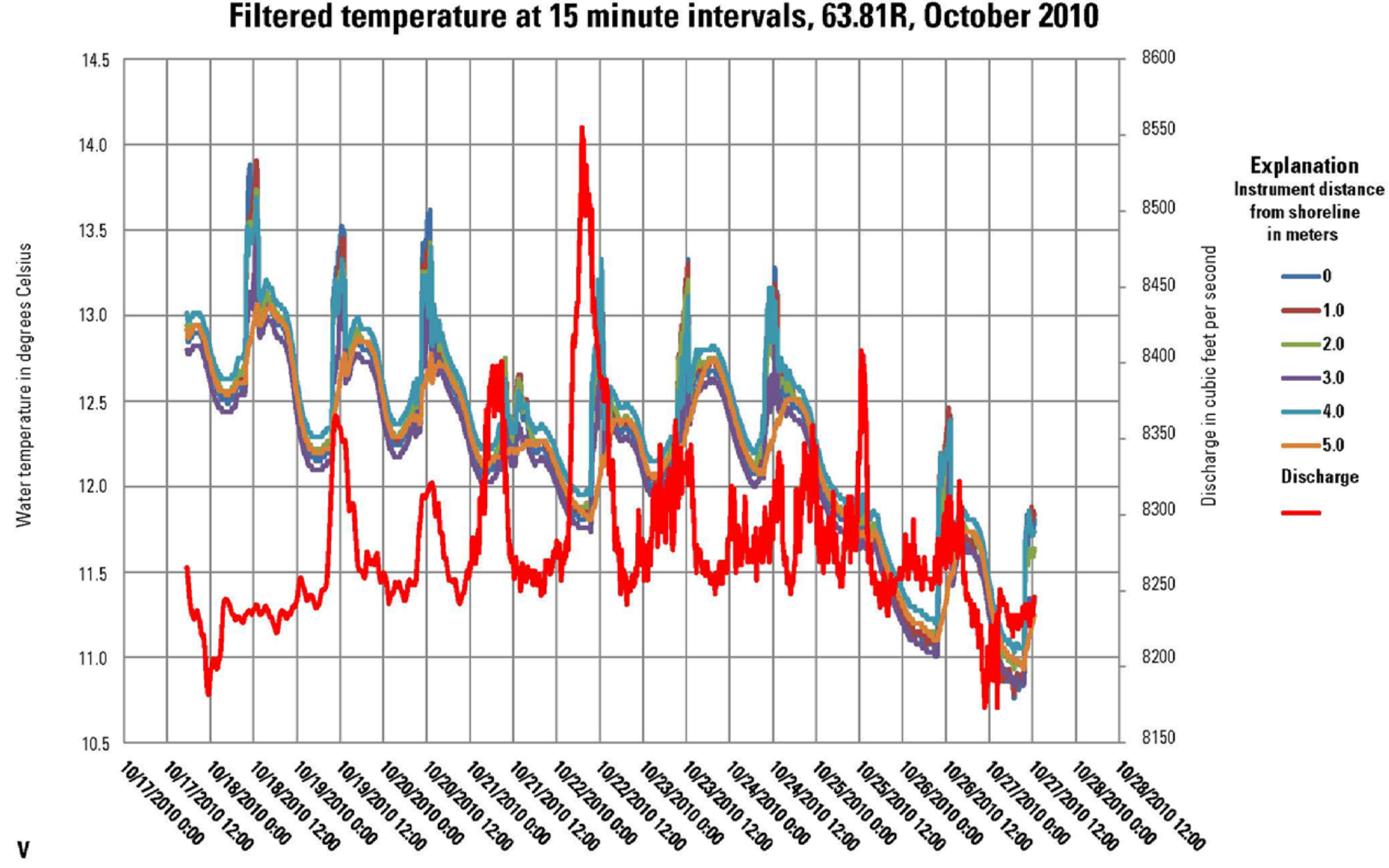


Filtered temperature at 15 minute intervals, 64.29R, 0ctober 2010

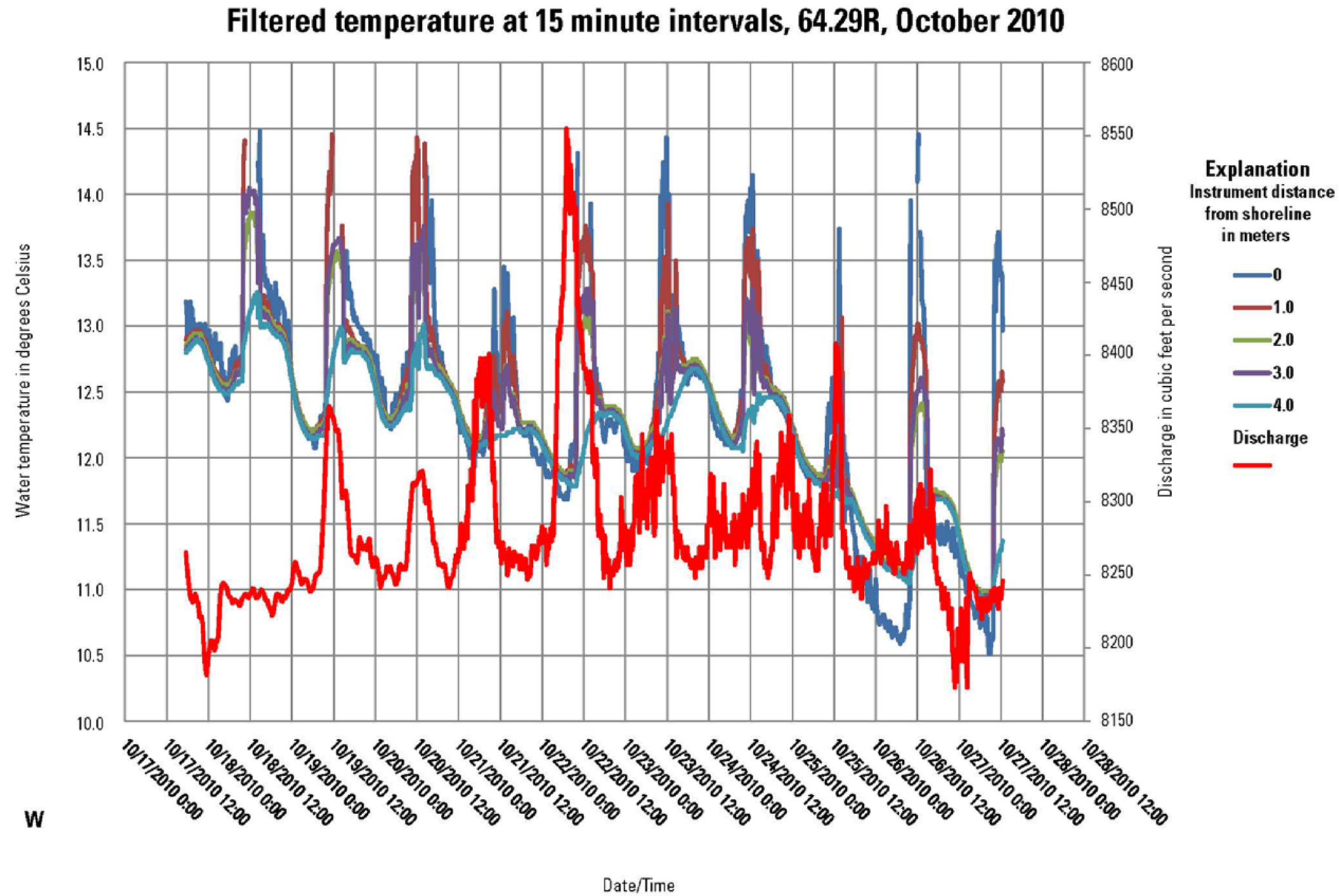


Filtered temperature at 15 minute intervals, $64.29 \mathrm{R}$ control, 0 ctober 2010

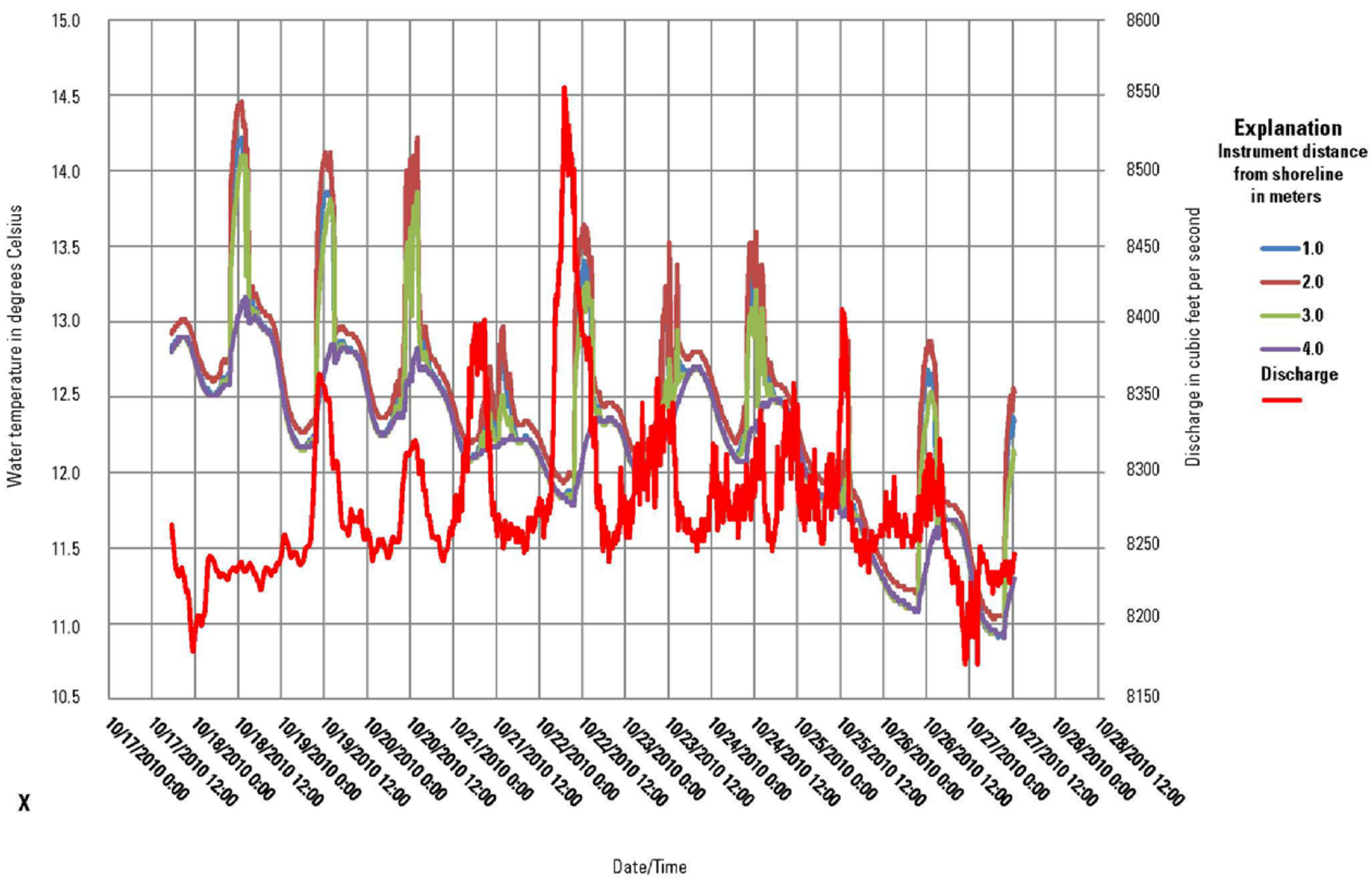


fered temperature at 15 minute intervals, 65.10L, 0ctober 2010

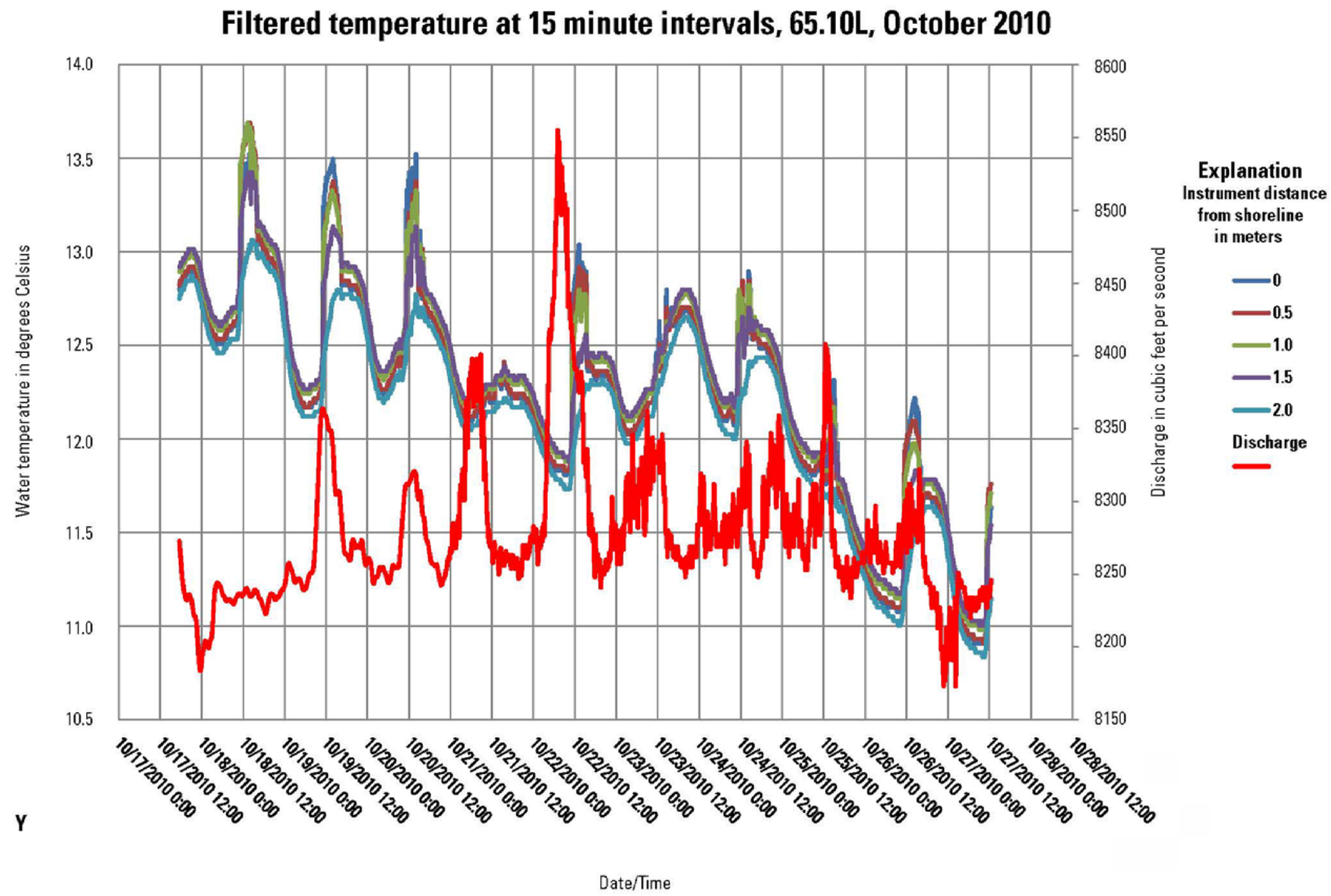


Filtered temperature at 15 minute intervals, 65.70L, 0ctober 2010

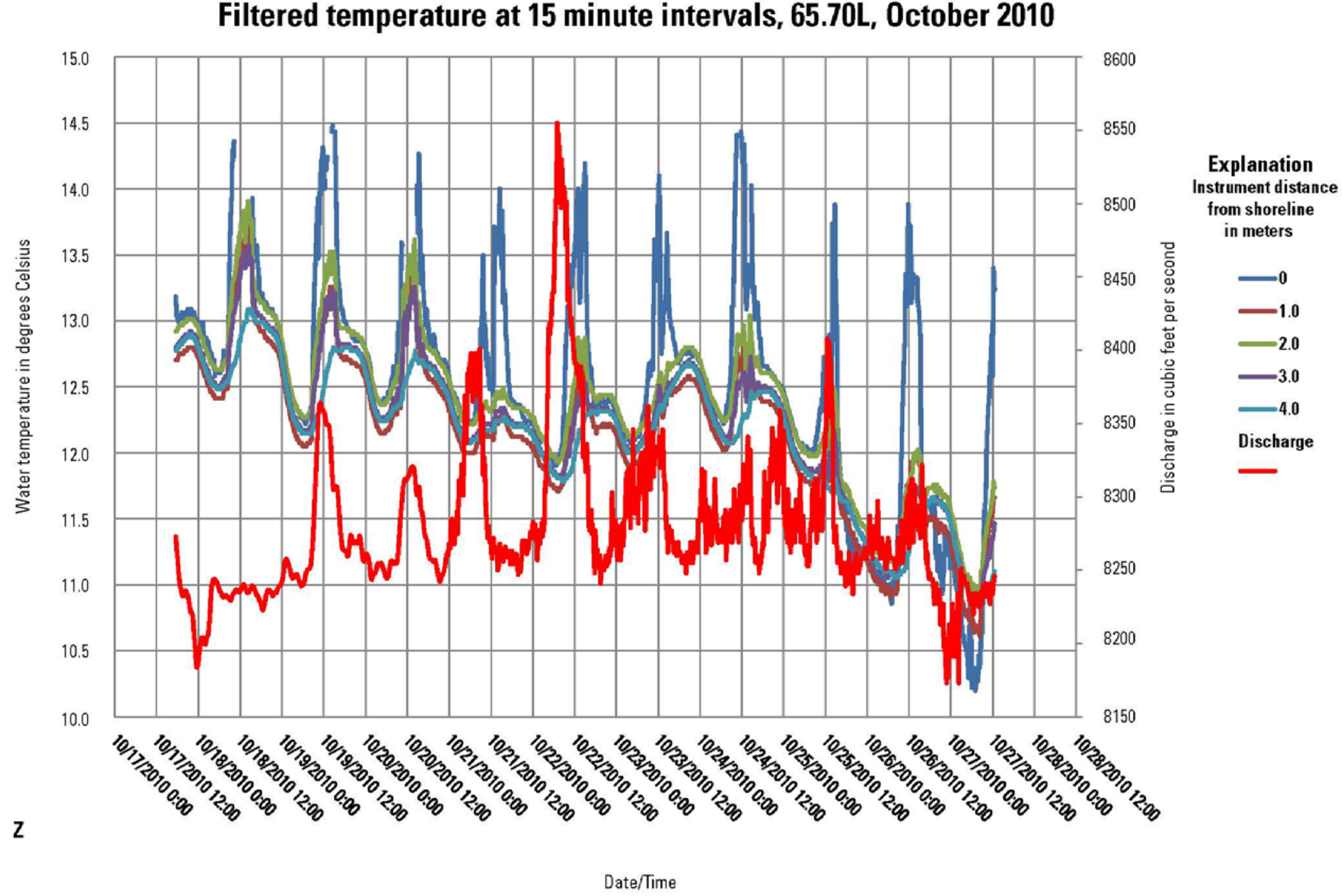


Filtered temperature at 15 minute intervals, 65.78L, 0ctober 2010

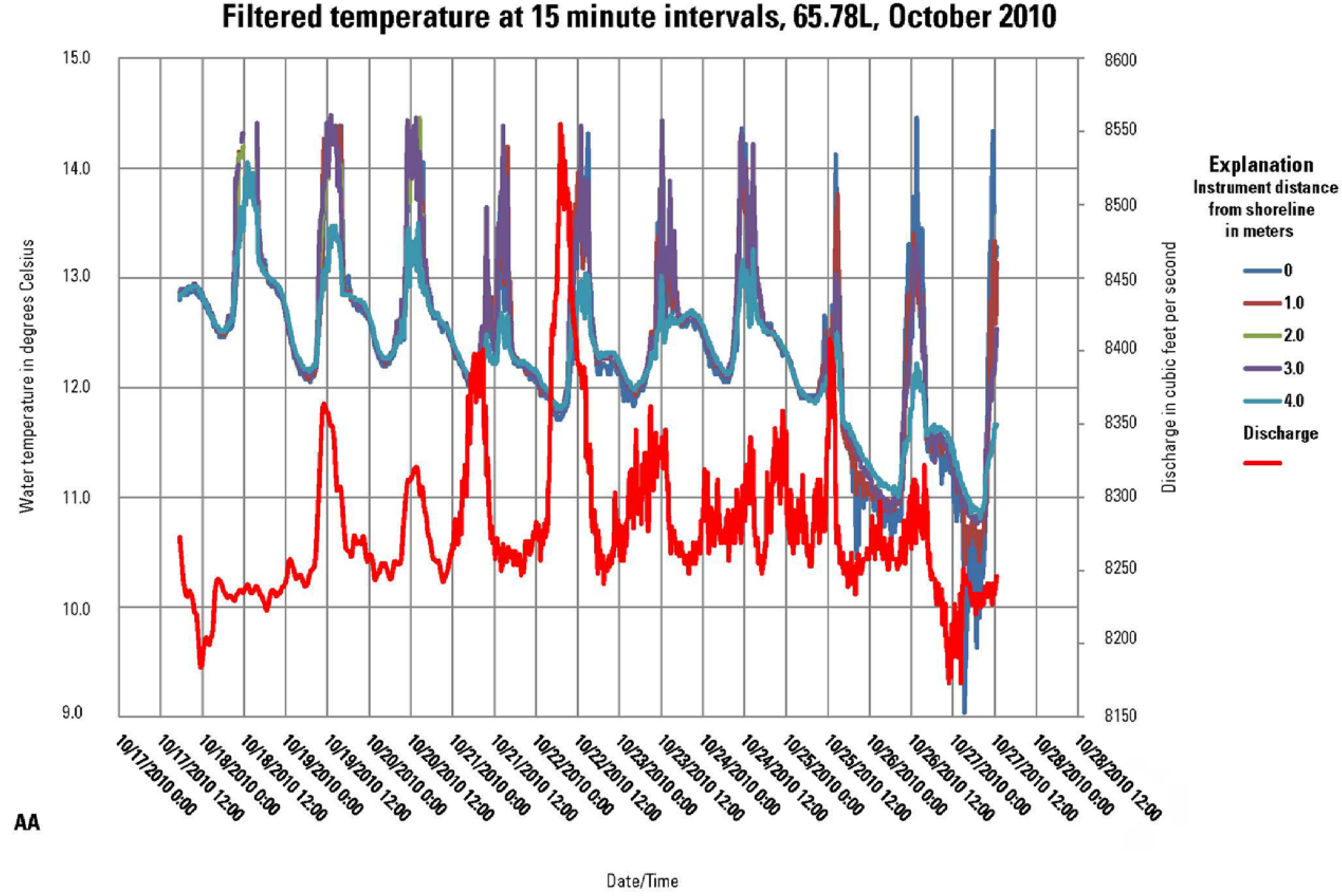

